GROUND-WATER RESOURCES OF COASTAL CITRUS, HERNANDO, AND SOUTHWESTERN LEVY COUNTIES, FLORIDA

By J. D. Fretwell

U.S. GEOLOGICAL SURVEY

Water-Resources Investigations Report 83-4079

Prepared in cooperation with the

SOUTHWEST FLORIDA WATER MANAGEMENT DISTRICT

Tallahassee, Florida 


\section{UNITED STATES DEPARTMENT OF THE INTERIOR \\ JAMES G. WATT, Secretary}

GEOLOGICAL SURVEY

Dallas L. Peck, Director

For additional information write to:

\section{District Chief}

U.S. Geological Survey

Suite 3015

227 North Bronough Street

Tallahassee, Florida 32301
Copies of this report can be purchased from:

Open-File Services Section Western Distribution Branch U.S. Geological Survey Box 25425, Federa1 Center Denver, Colorado 80225

(Telephone: (303) 234-5888) 
Abstract -

Introduction -

Purpose and scope -

Acknowledgments -_-_-_-_-_-_-_-_ 4

Description of the study area - 4

Physiography -_- 4

Land use - - 7

Surface-water features _-_- 7

Rivers, streams, and springs - 7

Lakes - -

C1imate -

Evapotranspiration -

Hydrogeology -

Sinkholes -

Occurrence of ground water - 15

Floridan aquifer - 19

Hydraulic properties -_- 19

Potentiometric surface -

Water use -

Water quality -

Saltwater encroachment -

Changes in chemical quality

Ground-water resource development

Summary and conclusions - 60

Selected references - 62

\section{ILLUSTRATIONS}

Figure 1. Map showing location of study area in west-central Florida --- 3

2. Graph showing past and projected population in Citrus,

Hernando, and Levy Counties _-_ 5

3. Map showing physiographic features - 6

4. Map showing locations of major surface-water features --_-_- 8

5. Graphs showing total monthly precipitation in 1980 at Brooksville, Weeki Wachee, and Inverness, and normal precipitation (1941-70) at Brooksville and Inverness -_-_-_ 12

6. Graph showing annual precipitation at Brooksville, Weeki Wachee, and Inverness - 13

7. Map showing difference between rainfall and potential evaporation -_-_- 14

8. Generalized geologic sections - 18

9. Map showing locations of aquifer-test sites - 
Figure 10. Map showing the potentiometric surface of the Floridan aquifer in the study area and surrounding areas in May 1980

11. Map showing the potentiometric surface of the Floridan aquifer in May and September 1980

12. Map showing locations of wells

13. Hydrographs showing water levels of the Floridan aquifer ----- 26

14. Hydrographs showing comparison of water levels in a well and tide levels

15. Graphs showing monthly industrial and irrigation freshwater use in the study area, 1980

16. Map showing permitted daily withdrawals of ground water from the Floridan aquifer for consumptive use, 1980

17. Stiff diagrams showing concentrations of major constituents in water from wells

18. Map showing distribution of dissolved solids in ground water at a depth of 100 feet below land surface -

19. Map showing distribution of carbonate hardness in ground water at a depth of 100 feet below land surface --_-_-_-- 44

20. Map showing distribution of iron in ground water at a depth of 100 feet below land surface

21. Map showing distribution of sulfate in ground water at a depth of 100 feet below land surface

22. Cross sections of the saltwater-freshwater zone of transition ---_-_-_-_-_-_-_-_-_-

23. Map showing the areal position of the 250-milligram-per-liter line of equal chloride concentration at 100 feet below sea level --_-_-_-_-_-_- 50

24. Graphs showing chloride concentrations in water from wells near the coast

25. Graph showing comparison of tidal fluctuations at Bayport with temperature and specific conductance of water from well 25, November 19 to 28, 1980

26. Geoelectric cross section near Homosassa Springs

27. Map showing saltwater-freshwater interface in the Floridan aquifer based on electrical resistivity compared to that based on well data

28. Map showing drawdown caused by pumping three hypothetical wells at different times to steady-state at a rate of 40 million gallons per day each

29. Map showing drawdown caused by pumping a hypothetical well in central Hernando County to steady-state at a rate of 40 million gallons per day 


\section{ILLUSTRATIONS - Continued}

Page

Figure 30. Map showing drawdown caused by pumping a hypothetical well in south-central Hernando County to steady-state at a rate of 40 million gallons per day

\section{TABLES}

Table 1. Instantaneous discharge measurements for minor springs and spring-fed rivers - 9

2. Generalized geologic column - 16

3. Transmissivity of the Floridan aquifer

4. Wells used to compile water-level and water-quality information -

5. Selected chemical constituents and physical properties of water -

6. Chemical analyses of water from wells

7. Chemical analyses of water from springs and spring-fed rivers -- 76 


\section{ABBREVIATIONS AND CONVERSION FACTORS}

Factors for converting inch-pound units to International System (SI) of Units and abbreviations of units

\section{Multiply}

inch (in)

foot $(f t)$

mile (mi)

square mile $\left(\mathrm{mi}^{2}\right)$

million gallons per day

(Mgal/d)

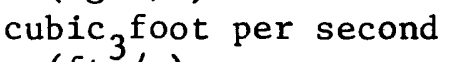

$\left(\mathrm{ft}^{3} / \mathrm{s}\right)$

foot squared per day

( $\mathrm{ft}^{2} / \mathrm{d}$ )

foot per day per foot
$[(f t / d) / f t]$

micromho per centimeter

at $25^{\circ}$ Celsius

$\left(\mu \mathrm{hmo} / \mathrm{cm}\right.$ at $\left.25^{\circ} \mathrm{C}\right)$

Transmissivity

0.04381

0.02832

0.09290

Leakance

1.000

Specific Conductance

1.000

\section{Length}

25.40

0.3048

1.609

\section{Area}

2.590

\section{Flow}

To obtain

millimeter (mm)

meter (m)

kilometer $(\mathrm{km})$

square kilometer $\left(\mathrm{km}^{2}\right)$

(

picocurie (pCi)

$\frac{\text { Radiation }}{0.037}$ cubig meter per second
$\left(\mathrm{m}^{3} / \mathrm{s}\right)$ cubig meter per second $\left(\mathrm{m}^{3} / \mathrm{s}\right)$ meter squared per day
$\left(\mathrm{m}^{2} / \mathrm{d}\right)$ meter per day per meter
$[(\mathrm{m} / \mathrm{d}) / \mathrm{m}]$ microsiemen per centi- meter at $25^{\circ}$ Celsius $\left(\mu \mathrm{S} / \mathrm{cm}\right.$ at $\left.25^{\circ} \mathrm{C}\right)$

* * * * $\quad$ * $\quad$ * $\quad * 37$ becquerel $(\mathrm{Bq})$

National Geodetic Vertical Datum of 1929 (NGVD of 1929).--A geodetic datum derived from a general adjustment of the first-order level nets of both the United States and Canada, formerly called mean sea level. In the text of this report, NGVD of 1929 is referred tn as sea level.

* $\quad * \quad * \quad * \quad * \quad * \quad * \quad * \quad * \quad * \quad *$




\title{
GROUND-WATER RESOURCES OF COASTAL CITRUS, HERNANDO, AND SOUTHWESTERN LEVY COUNTIES, FLORIDA
}

\author{
By J. D. Fretwell
}

\begin{abstract}
Ground water in the coastal parts of Citrus, Hernando, and Levy Counties is obtained almost entirely from the Floridan aquifer. Water enters the aquifer as infiltration of precipitation or as ground-water flow from outside the area. Ground-water flow is toward the Gulf of Mexico in the limestone and dolomite of the Floridan aquifer, and natural discharge is through coastal springs and upward leakage in marshlands.

The aquifer is composed of one or more of the following Tertiary formations in order of increasing age: the Suwannee Limestone, Ocala Limestone, Avon Park Limestone, and that part of the Lake City Limestone above the evaporites. The aquifer increases in thickness from about 700 feet in the north to about 1,000 feet in the south. The Floridan aquifer is unconfined near the coast. In inland areas, where sands and clays are present, the aquifer is semiconfined.

Transmissivity of the Floridan aquifer was estimated to range from 20,000 feet squared per day in the northeast corner of the study area in Levy County, to 2,000,000 feet squared per day at several springs. Transmissivities are generally larger at springs and decrease radially away from them.

The potentiometric surface of the aquifer changes very little between the wet and dry seasons. This small change is related to seasonal variations in rainfall. The potentiometric surface has changed little from 1965 to 1980 due to relatively little ground-water development.

Chemical constituents increase in concentration toward the coast and with depth. Water quality is generally good except in areas adjacent to the coast where saltwater intrusion from the Gulf of Mexico poses a threat to the freshwater supply. Increased ground-water withdrawal associated with increased population and demand on water resources could lower the potentiometric surface, and seawater could move inland into the water supply. This threat can be lessened by placing well fields adequate distances from the saltwater-freshwater zone of transition so as not to reduce or reverse the hydraulic gradient adjacent to the coast.
\end{abstract}


Coastal Citrus, Hernando, and Levy Counties lie within the Coastal Rivers and Withlacoochee Basins of the Southwest Florida Water Management District (fig. 1). This area has experienced rapid population growth from 1960-80 and the trend is expected to continue through the year 2020 (University of Florida, 1979 ; 1980a; 1980b). Growth is from increasing numbers of small communities and associated businesses and industry. At present (1982), the area does not have a regional water-supply system and each community or industry must develop its own. However, a regional water-supply system is being considered.

The principal source of water in the area is ground water from the Floridan aquifer. In 1980, an estimated $44 \mathrm{Mgal} / \mathrm{d}$ of ground water was used.

Conversations with well owners in the study area indicated problems related to ground water that they had encountered or suspected. Among these problems were high concentrations of chloride, sulfate, iron, and phosphorus, poor yields from some wells that had identical construction to nearby wells that had good yields, and sinkhole development.

Ground-water development in coastal areas presents special water management problems, primarily related to the threat of saltwater intrusion. Numerous wells in the area have shown increases in chloride concentrations in water. Increases in chloride, a major chemical constituent of saltwater, are used as an indicator of saltwater intrusion. Citizens and water managers have become concerned about increases in chloride concentrations in water from wells along the coast and are becoming aware of the threat of saltwater intrusion and the possible adverse effects on the quality and quantity of ground water available for development.

\section{Purpose and Scope}

In 1980 , the U.S. Geological Survey, in cooperation with the Southwest Florida Water Management District, initiated an investigation to appraise the ground-water resources of coastal parts of Citrus, Hernando, and Levy Counties that are within the Southwest Florida Water Management District and to provide information necessary for the use and protection of the resource. The appraisal includes descriptions of the geography, geology, surface-water features, and ground-water resources, which include information on the water quality and hydraulic properties of the Floridan aquifer. Possible impacts from various ground-water development schemes were also evaluated. Information included in this report is based on data collected during the study (1980-81), historical data from the files of the U.S. Geological Survey and the Southwest Florida Water Management District, and from previously published reports. This report is intended to provide an understanding of the hydrogeology of the area and provide a basis for effective ground-water management. 


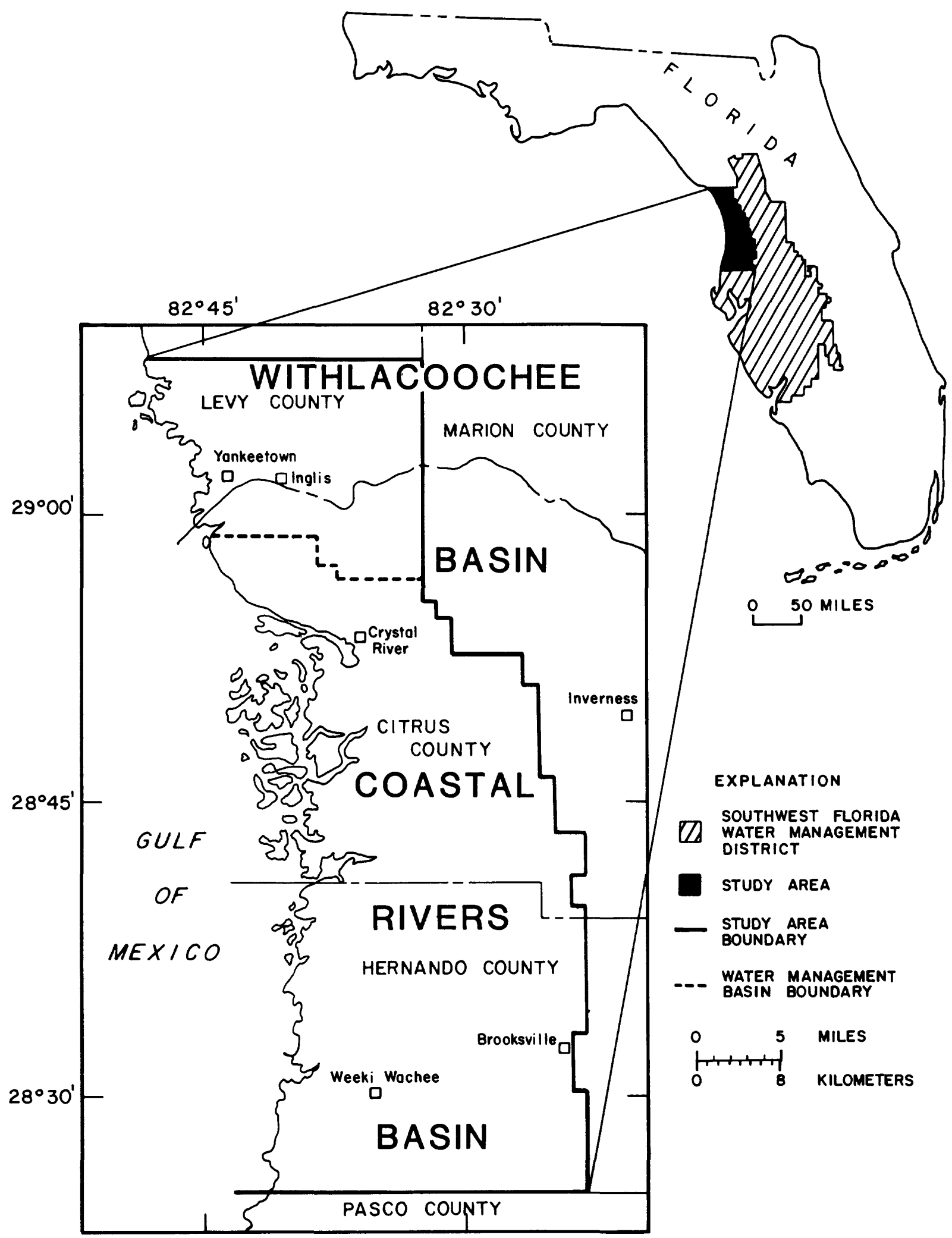

Figure 1.--Location of study area in west-central Florida. 


\section{Acknowledgments}

The author gratefully acknowledges assistance provided by many organizations and individuals in conducting this investigation. Personnel of the Southwest Florida Water Management District provided valuable information. The author is grateful to the many well owners who permitted access to their land and allowed sampling of water and measuring of water levels in their wells.

\section{DESCRIPTION OF THE STUDY AREA}

The study area includes all parts of Citrus and Hernando Counties within the Coastal Rivers Basin and the coastal parts of Citrus and Levy Counties within the Withlacoochee Basin within about 15 miles of the coast, an area of about $720 \mathrm{mi}^{2}$ (fig. 1).

Rapid increases in population have occurred in Citrus, Hernando, and Levy Counties in the past 20 years, as shown on figure 2. This trend is expected to continue through the year 2020 (University of Florida, 1979; 1980a; 1980b). During the past decade, the population of Citrus County increased from more than 19,000 to more than 53,000 (177 percent); Hernando County showed an increase from 17,000 to almost 44,000 (158 percent); and Levy County, a rural area, increased from less than 13,000 to more than 19,000 (52 percent). The largest municipality in the area is Brooksville in Hernando County with a population of 5,600 in 1980 . The second largest municipality is Crystal River in Citrus County with a population of 2,800 in 1980. Within the study area, the largest city in Levy County is Inglis with a population of 1,200 in 1980. Eighty-three percent of the population in the three counties live in unincorporated areas.

\section{Physiography}

The study area (fig. 3) lies within the Gulf Coastal Lowlands and Central Highlands physiographic divisions described by Puri and Vernon (1964). The lowlands are subdivisions of the Coastal Plain Province as described by Fenneman (1938). Land altitudes range from sea level at the Gulf Coast to more than 200 feet above sea level in the highlands.

The Central Highlands are characterized by the northwest-southeast trending Brooksville Ridge (White, 1970). This series of eroded ridges consists of limestone and clay hills of the Suwannee and Ocala Limestones, interbedded limestone and clay of the Hawthorn Formation, and sands and clays of the Alachua Formation. Local relief along the ridges is a result of numerous sinks and depressions characteristic of karst topography.

The dominant features of the Coastal Lowlands are two gently sloping Pleistocene terraces that consist of the Wicomico Formation and the Pamlico Sand, defined at their landward side by elevations of 100 and 25 feet. The Wicomico terrace slopes gently to the west between the western flank of the Brooksville Ridge and the eastern extent of the Pamlico terrace. The Pamlico terrace is submerged on its coastal side. The submerged part of the terrace retains many of the features of the emergent part, such as sinkholes and springs. This terrace supports salt marshes and swamps along the coast that give way to hardwood forests and sand ridges in a landward direction (Wetterha11, 1964). 


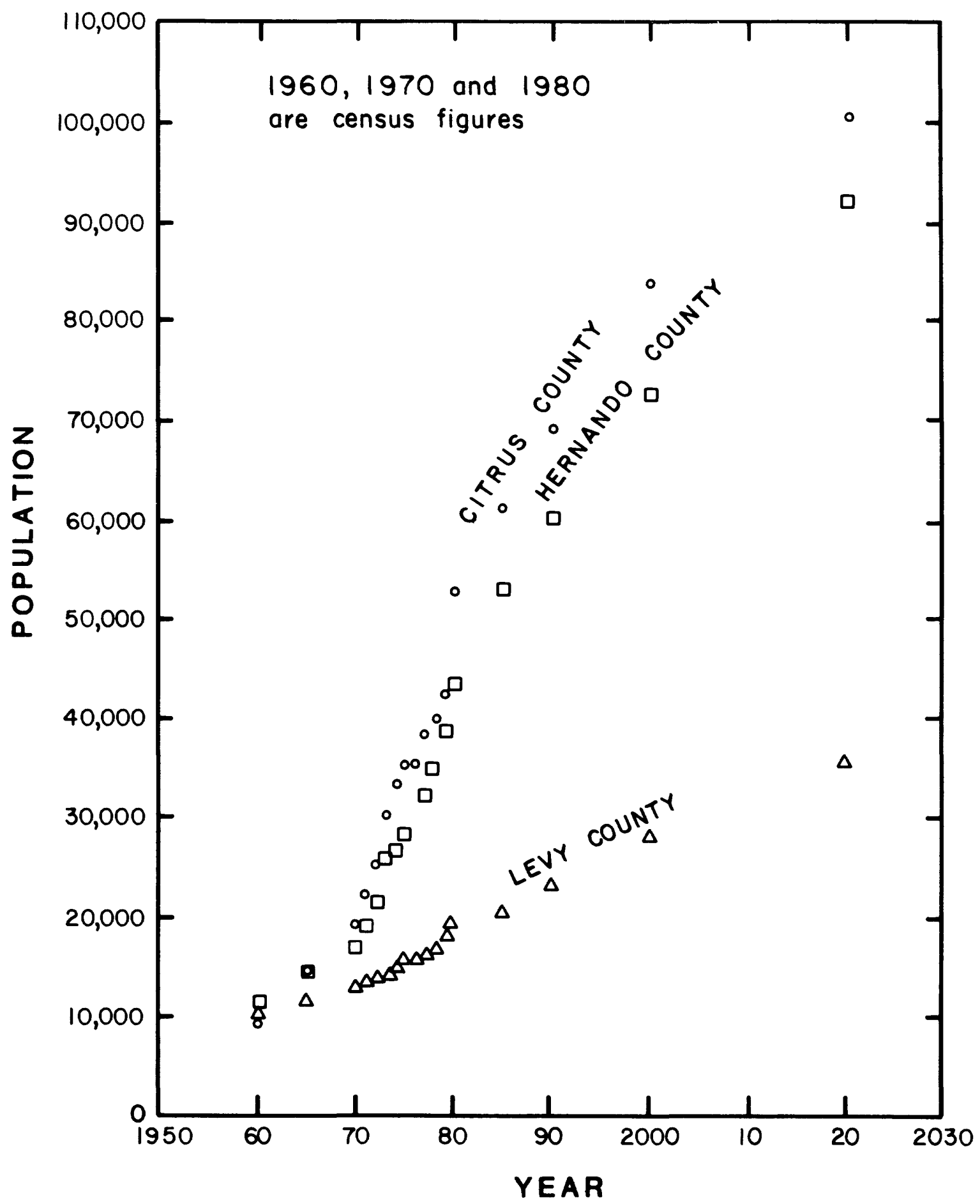

Figure 2.--Past and projected population in Citrus, Hernando, and Levy Counties (University of Florida, 1979; 1980a; 1980b). 


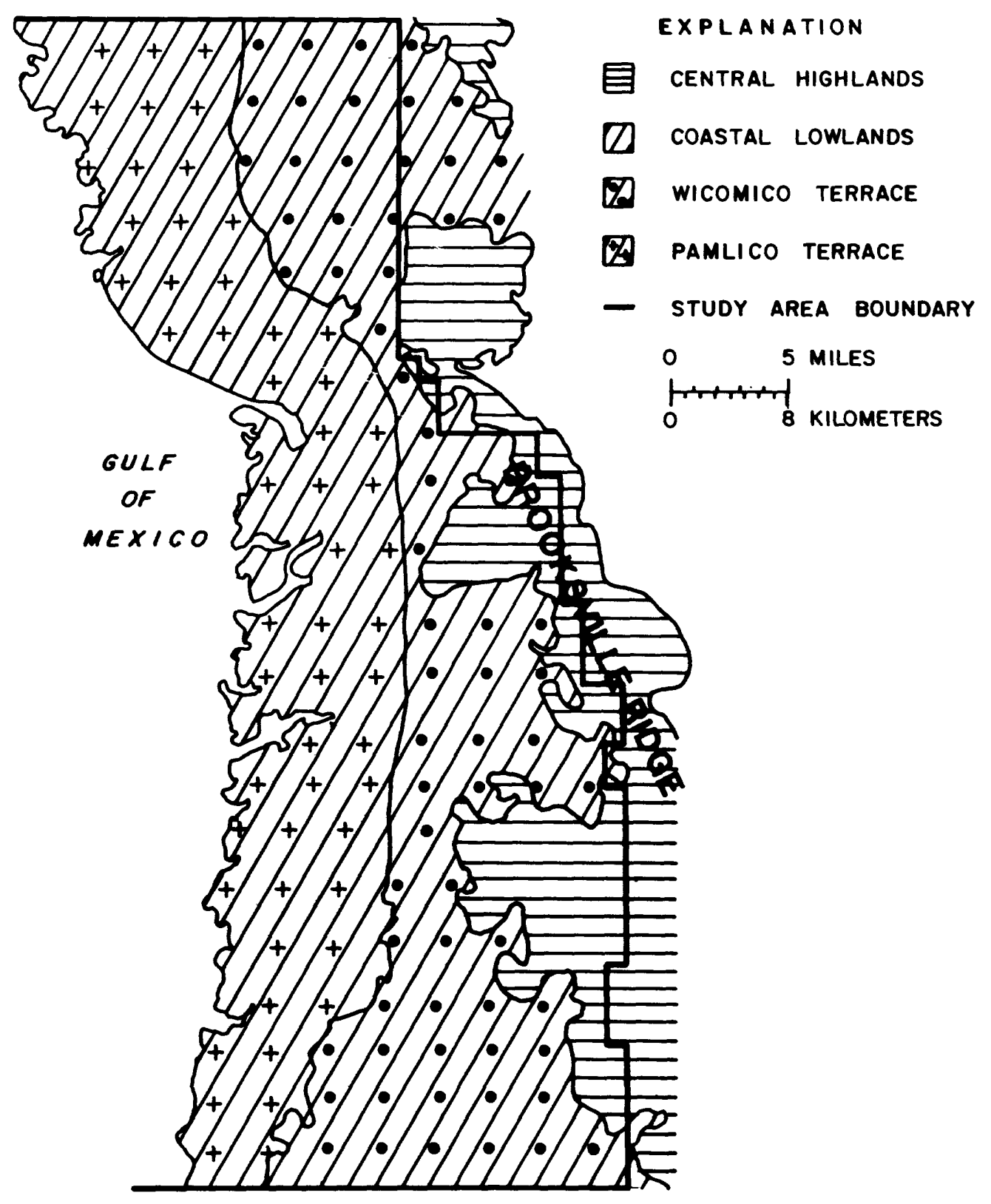

Figure 3.--Physiographic features (modified from Puri and Vernon, 1964). 
In 1975, major land-use classifications in the study area were wetlands made up of salt marshes and swamps along the coast and forest land interspersed with croplands and pasture in the east (Southwest Florida Water Management District, 1976). Urban land use, in the form of small housing developments and towns, occurs along the coastal fringe of the forest land and in the Brooksville area. Quarries represent a substantial amount of land use in north-central Hernando County and can be found throughout the study area. Projected changes in land use from 1975 to 1985 include expanded residential areas and related commercial growth along the coast (Southwest Florida Water Management District, 1976). Projections for the year 2035 indicate continued expansion of residential and commercial growth along the coast moving toward Brooksville in the south and along the Withlacoochee River in the north and some industrial expansion in the present forest land.

\section{Surface-Water Features}

\section{Rivers, Streams, and Springs}

Surface drainage is poorly developed landward of the coastal springs. The Withlacoochee River that separates Citrus and Levy Counties in the northern part of the study area (fig. 4) is the only major river that provides surface drainage from the interior of the study area. This river originates in the Green Swamp, about 20 miles east of the study area. Numerous springs and seeps along its course discharge water from the Floridan aquifer to the river. Near Lake Rousseau, the river and lake recharge the aquifer. The average river discharge at Inglis Dam, about 11 miles upstream from the coast, was $351 \mathrm{ft} / \mathrm{s}$ from 1969 to 1980 . The river is affected by tides below the dam.

Al1 other major rivers are in the coastal areas and discharge water from the Floridan aquifer. These include the Weeki Wachee, Chassahowitzka, Homosassa, and Crystal Rivers. Each of these rivers originates from a spring or group of springs. These springs represent 4 of the 27 first-order magnitude springs in Florida. A first-order magnitude spring has an average discharge of $100 \mathrm{ft} / \mathrm{s}$ or more. These springs are the Crystal River Springs (at least 30 known springs with a combined average discharge of approximately $\left.916 \mathrm{ft}^{3} / \mathrm{s}\right)$ at the head of the Crystal River, Homosassa Springs (average discharge $175 \mathrm{ft}^{3} / \mathrm{s}$ ) at the head of the Homosassa River, Chassahowitzka Springs (average discharge $139 \mathrm{ft} / \mathrm{s}$ ) at the heagd of the Chassahowitzka River, and Weeki Wachee Springs (average discharge $176 \mathrm{ft}^{3} / \mathrm{s}$ ) at the head of the Weeki Wachee River. The rivers are tidally affected as they flow through coastal marshlands toward the gulf.

Numerous smaller springs and spring-fed streams drain the coastal fringes of the mainland and marshes. Instantaneous discharge measurements for these are given in table 1. Combined springflow for some of these sites is greater than $100 \mathrm{ft}^{3} / \mathrm{s}$; however, no single spring in this list is a first-order magnitude spring. Some streams begin from springs or seeps, flow overland some distance, and disappear into sinkholes. Hidden River near Homosassa is an example of this. It originates in seeps, flows about 2 miles, and then disappears underground. Water in streams within the marshes is a complex of saline and freshwater; the salinity varies with tide, depth of origin of the ground water, and proximity to the gulf. Flow is affected by the tide in many of the springs that are located near the coast. 


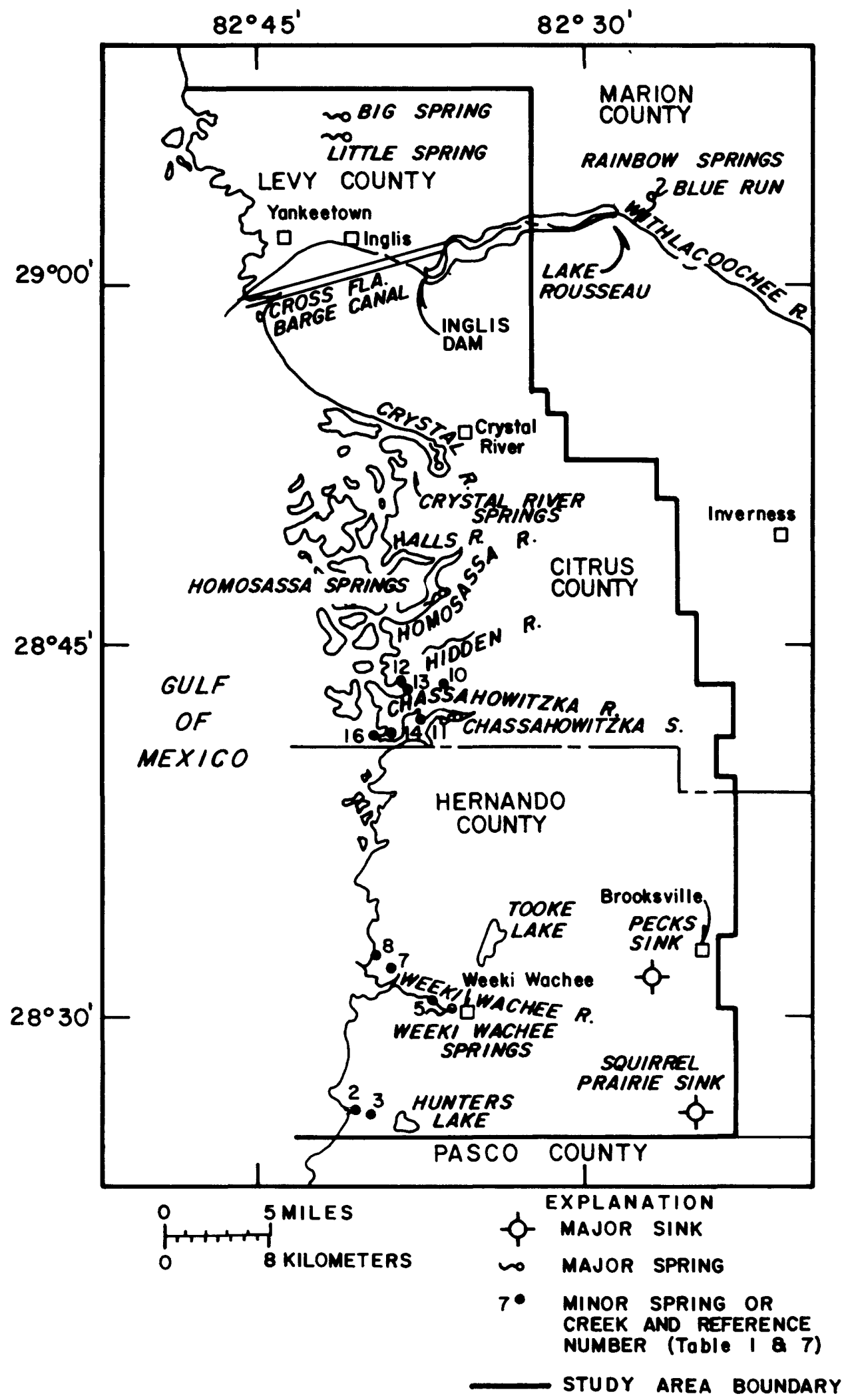

Figure 4.--Locations of major surface-water features. 
Table 1.--Instantaneous discharge measurements for minor springs and spring-fed rivers

\begin{tabular}{|c|c|c|c|}
\hline $\begin{array}{l}\text { Site } \\
\text { No. }\end{array}$ & Station name & $\begin{array}{c}\text { Date of } \\
\text { measurement }\end{array}$ & $\begin{array}{l}\text { Streamflow, } \\
\text { instantaneous } \\
\left(\mathrm{ft}^{3} / \mathrm{s}\right)\end{array}$ \\
\hline 2 & Boat Spring & $4-30-64$ & 1.5 \\
\hline 3 & Bobhill Springs & $\begin{array}{r}10-13-64 \\
8-06-65 \\
12-15-72\end{array}$ & $\begin{array}{l}3.7 \\
4.3 \\
2.0\end{array}$ \\
\hline 4 & Magnolia Springs & $\begin{array}{r}10-13-64 \\
2-04-65 \\
8-05-65 \\
12-12-72\end{array}$ & $\begin{array}{r}9.1 \\
9.4 \\
10.0 \\
.9\end{array}$ \\
\hline 5 & Little Springs & $\begin{array}{r}3-03-61 \\
7-24-64 \\
10-14-64 \\
2-04-65 \\
8-06-65 \\
12-15-72\end{array}$ & $\begin{array}{r}18.0 \\
19.0 \\
38.0 \\
25.0 \\
33.0 \\
7.8\end{array}$ \\
\hline 7 & Salt Spring & $\begin{array}{r}1-18-61 \\
1-28-65 \\
1-30-66 \\
12-14-72\end{array}$ & $\begin{array}{l}25.0 \\
39.0 \\
28.0 \\
32.0\end{array}$ \\
\hline 8 & Mud River & $1-18-61$ & 128.0 \\
\hline 10 & Crab Creek & $\begin{array}{r}3-18-64 \\
7-21-64 \\
10-15-64 \\
1-27-65 \\
8-05-65\end{array}$ & $\begin{array}{l}44.0 \\
49.0 \\
49.0 \\
43.0 \\
46.0\end{array}$ \\
\hline 11 & Baird Creek & $\begin{array}{r}4-10-64 \\
7-21-64 \\
10-14-64 \\
1-27-65 \\
8-05-65\end{array}$ & $\begin{array}{l}22.0 \\
24.0 \\
53.0 \\
34.0 \\
44.0\end{array}$ \\
\hline 12 & Ruth Springs & $\begin{array}{r}4-14-64 \\
7-21-64 \\
10-15-64 \\
1-27-65 \\
8-05-65 \\
12-14-72\end{array}$ & $\begin{array}{r}6.6 \\
8.0 \\
7.4 \\
8.3 \\
12.0 \\
10.0\end{array}$ \\
\hline 13 & Potters Creek & $\begin{array}{r}11-29-61 \\
4-14-64\end{array}$ & $\begin{array}{l}32.0 \\
25.0\end{array}$ \\
\hline 14 & Crawford Creek & $\begin{array}{l}4-14-64 \\
7-22-64\end{array}$ & $\begin{array}{l}21.0 \\
35.0\end{array}$ \\
\hline 16 & Ryle Creek & $\begin{array}{r}11-29-61 \\
4-16-64\end{array}$ & $\begin{array}{r}.5 \\
26.0\end{array}$ \\
\hline
\end{tabular}


Table 1.--Instantaneous discharge measurements for minor springs and spring-fed rivers--Continued

\begin{tabular}{|c|c|c|c|}
\hline $\begin{array}{c}\text { Site } \\
\text { No. }\end{array}$ & Station name & $\begin{array}{c}\text { Date of } \\
\text { measurement }\end{array}$ & $\begin{array}{l}\text { Streamflow, } \\
\text { instantaneous } \\
\left(\mathrm{ft}^{3} / \mathrm{s}\right)\end{array}$ \\
\hline 19 & Halls River & $\begin{array}{r}3-27-64 \\
7-15-64 \\
10-08-64 \\
8-02-65 \\
9-08-65 \\
10-21-65 \\
11-23-65 \\
12-22-65 \\
1-19-66 \\
3-09-66 \\
6-14-66\end{array}$ & $\begin{array}{r}168.0 \\
96.0 \\
227.0 \\
257.0 \\
120.0 \\
98.0 \\
291.0 \\
207.0 \\
191.0 \\
112.0 \\
59.0\end{array}$ \\
\hline 20 & Middle Springs & $\begin{array}{l}3-25-64 \\
2-03-65 \\
8-04-65\end{array}$ & $\begin{array}{l}15.0 \\
15.0 \\
36.0\end{array}$ \\
\hline 21 & Saragassa Canal & $\begin{array}{l}3-25-63 \\
2-03-65 \\
8-03-65\end{array}$ & $\begin{array}{l}179.0 \\
190.0 \\
218.0\end{array}$ \\
\hline
\end{tabular}

Coastal marshes grade from saltwater habitats seaward and along marsh creeks to freshwater habitats at the landward side. Small creeks, usually less than 3 feet deep (Thom, 1967), "flood the marshes during high tide, but may be dry during low tide. Large creeks and channels carry freshwater to the gulf and bring tidal waters into the marsh. The creeks and channels usually originate at springs or seeps where water is discharged from the aquifer.

Marshes behave very much like a diffuse spring (P. D. Ryder, U.S. Geological Survey, oral commun., 1982). The amount of upward leakage of freshwater to the marshes is dependent upon the amount of recharge to the aquifer. Marsh waters become saltier when freshwater discharge is reduced.

In this report, springs refer to a ground-water discharge site with a distinct orifice. Discharge from a seep represents a much smaller discharge rate than a spring.

\section{Lakes}

Few large lakes exist within the study area, although there are several small sinkhole lakes. The largest lake, Lake Rousseau, is formed by the Inglis Dam on the Withlacoochee River ( $\mathrm{fig}, 4)$. Lake Rousseau is about 11 miles long and has a surface area of about $6.3 \mathrm{mi}^{2}$. The normal lake elevation is 27.5 feet above sea level (German, 1977). Water in the lake is derived predominantly from the Withlacoochee River and from Blue Run, the outlet of Rainbow Springs (fig. 4) that feeds into the Withlacoochee River. Rainbow Springs is a first-order magnitude spring in Marion County (Ferguson and others, 1947; Rosenau and others, 1977). 
Two other lakes in the study area are Hunter's Lake in southwest Hernando County and Tooke Lake in west-central Hernando County (fig. 4). The lakes have average surface areas of about $1 \mathrm{mi}^{2}$ and about $0.5 \mathrm{mi}^{2}$, respectively. Little is known about their interconnection with the aquifer, although they apnear to be spring fed.

\section{$\underline{\text { Climate }}$}

The climate in the coastal area of west-central Florida is characterized by long, warm, humid summers and mild, relatively dry winters. Average monthly temperatures range from the mid 50's in winter to the low $80^{\prime}$ 's in summer.

About 60 percent of rainfall in the area occurs between June and September (fig. 5) in the form of intense, local thunderstorms of short duration and occasional severe storms associated with tropical depressions. The lowest monthly rainfall generally occurs in November with a normal at Inverness of 1.5 inches and at Brooksville of 1.8 inches. The highest monthly rainfall is in August with a normal of 9.8 inches at Inverness and 9.6 inches at Brooksville (National Oceanic and Atmospheric Administration, 1980). Deviations in precipitation from normal are frequent and extreme, as shown on figure 5.

Total annual rainfall was near normal during 1979-80 for both Inverness and Brooksville based on the 30-year period 1941 through 1970 (fig. 6). The Weeki Wachee station has not been operating long enough to establish records showing normal rainfall.

\section{Evapotranspiration}

Evapotranspiration is the discharge of water from the Earth's surface to the atmosphere by evaporation from surface-water bodies and land surface and by transpiration from plants. Potential evaporation is generally considered equal to lake evaporation and expresses the amount of evaporation that would occur from shallow surface-water bodies. This is generally higher than actual evapotranspiration that takes into account vegetative transpiration.

A "life zone" bioclimatic classification system that takes vegetative cover into account (Holdridge, 1967) was used by Dohrenwend (1977) to calculate actual evapotranspiration throughout Florida based on 5 years of record at 21 stations. Potential evapotranspiration was estimated to be about 43 inches in the study area. Values increased from 41 inches in the north to 45 inches in the south. Actual evapotranspiration was calculated to average about 37 inches annually.

To assess aquifer recharge and surface- and ground-water outflow from a basin, it is necessary to know the difference between rainfall and evaporative losses. According to Visher and Hughes (1969), the annual difference between rainfall and potential evaporation (lake evaporation) ranges from zero in marsh and swamp areas at the coast to as much as 10 inches near Brooksville (fig. 7). A difference of nearly 20 inches was calculated in Dohrenwend's (1977) study that takes into account vegetative cover. A study by Cherry and others (1970, p. 79) that included part of this study area showed precipitation exceeded evapotranspiration by 37 inches for the period June 1964 through May 1966, an average of 18.5 inches per year. Hence, an average of approximately 18 to 20 inches of water per year is available for recharge to the aquifer or surface runoff. 

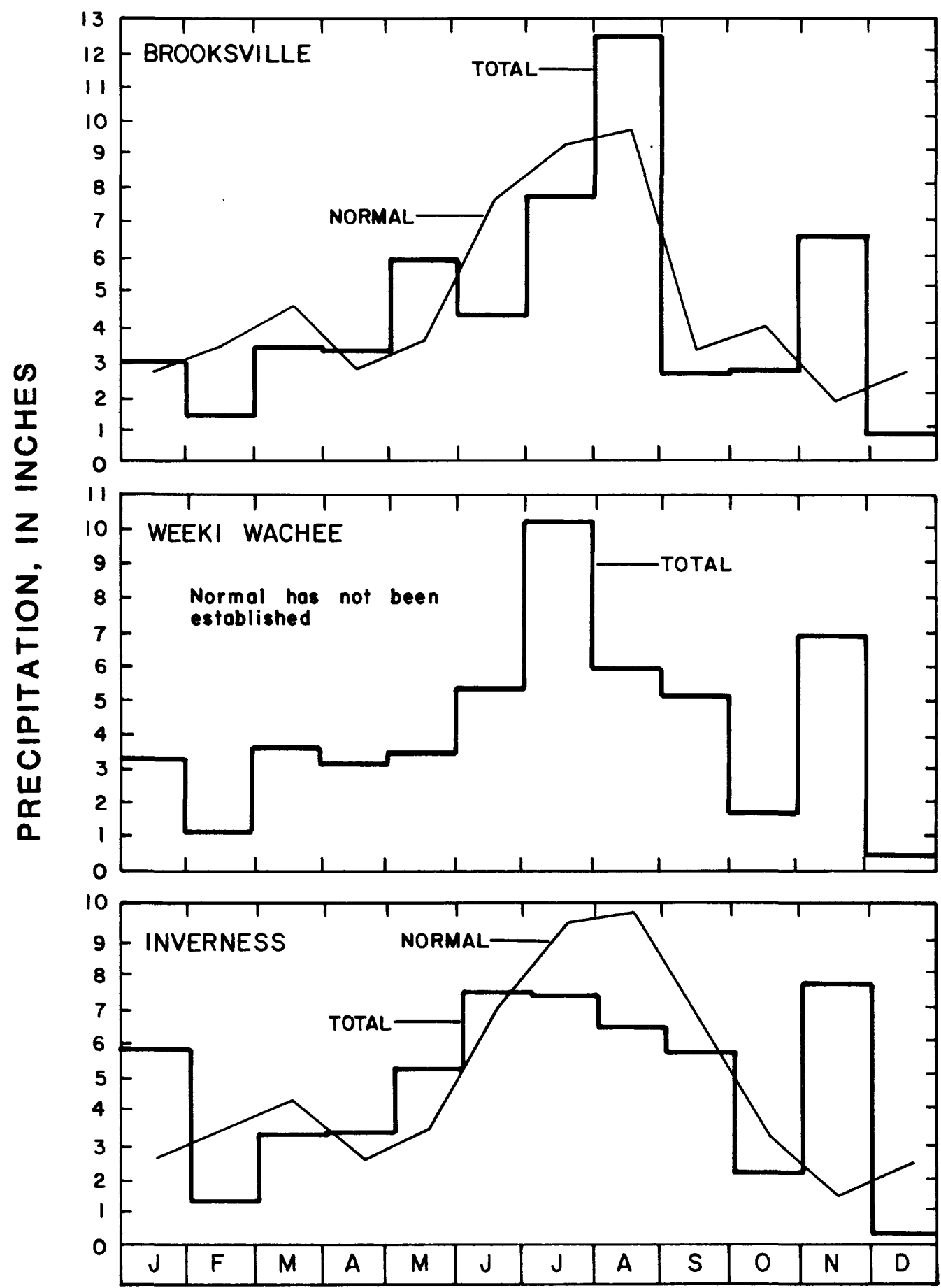

1980

Figure 5.--Total monthly precipitation in 1980 at Brooksville, Weeki Wachee, and Inverness, and normal precipitation (1941-70) at Brooksville and Inverness. 


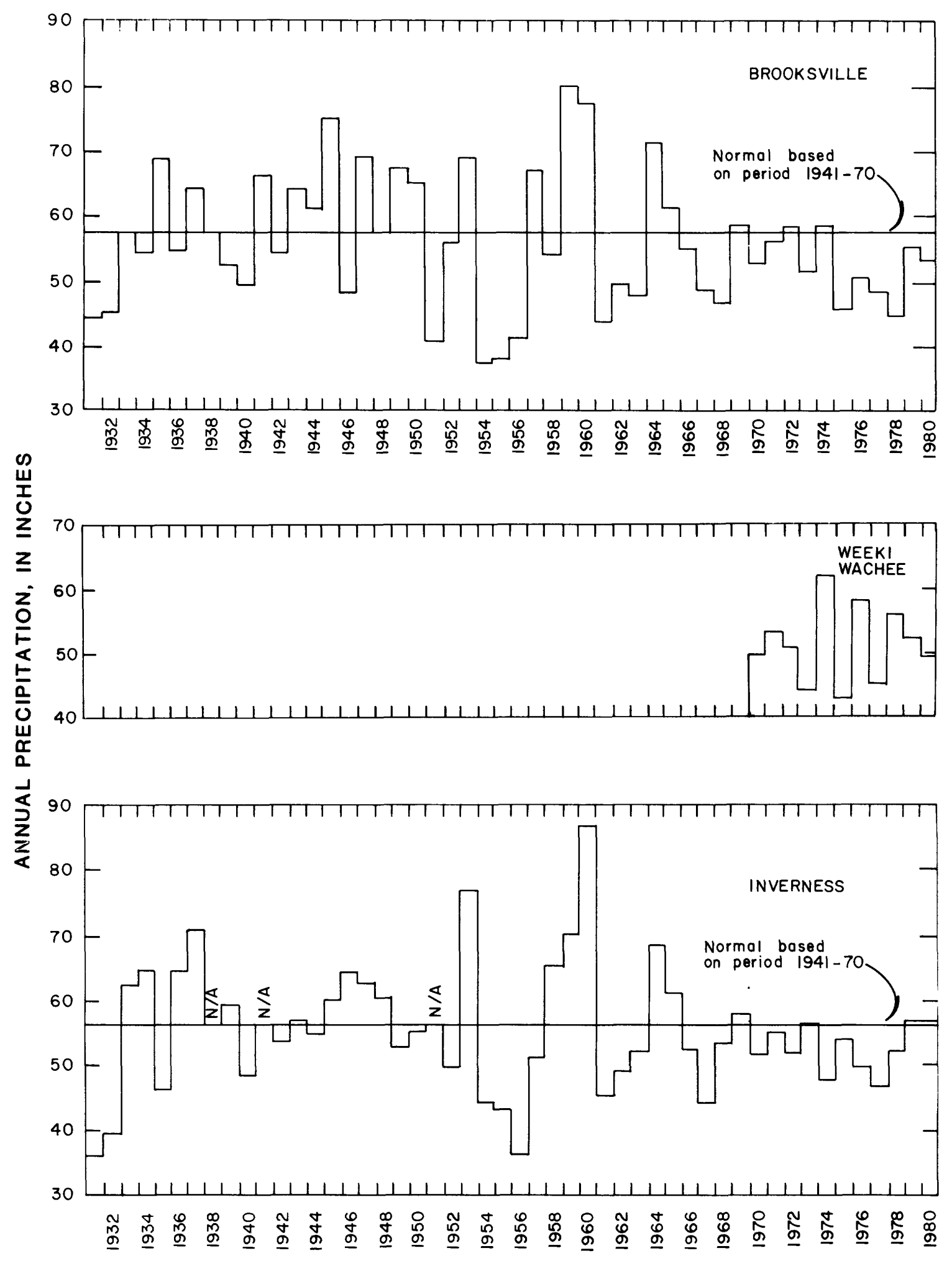

Figure 6.--Annual precipitation at Brooksville, Weeki Wachee, and Inverness. 


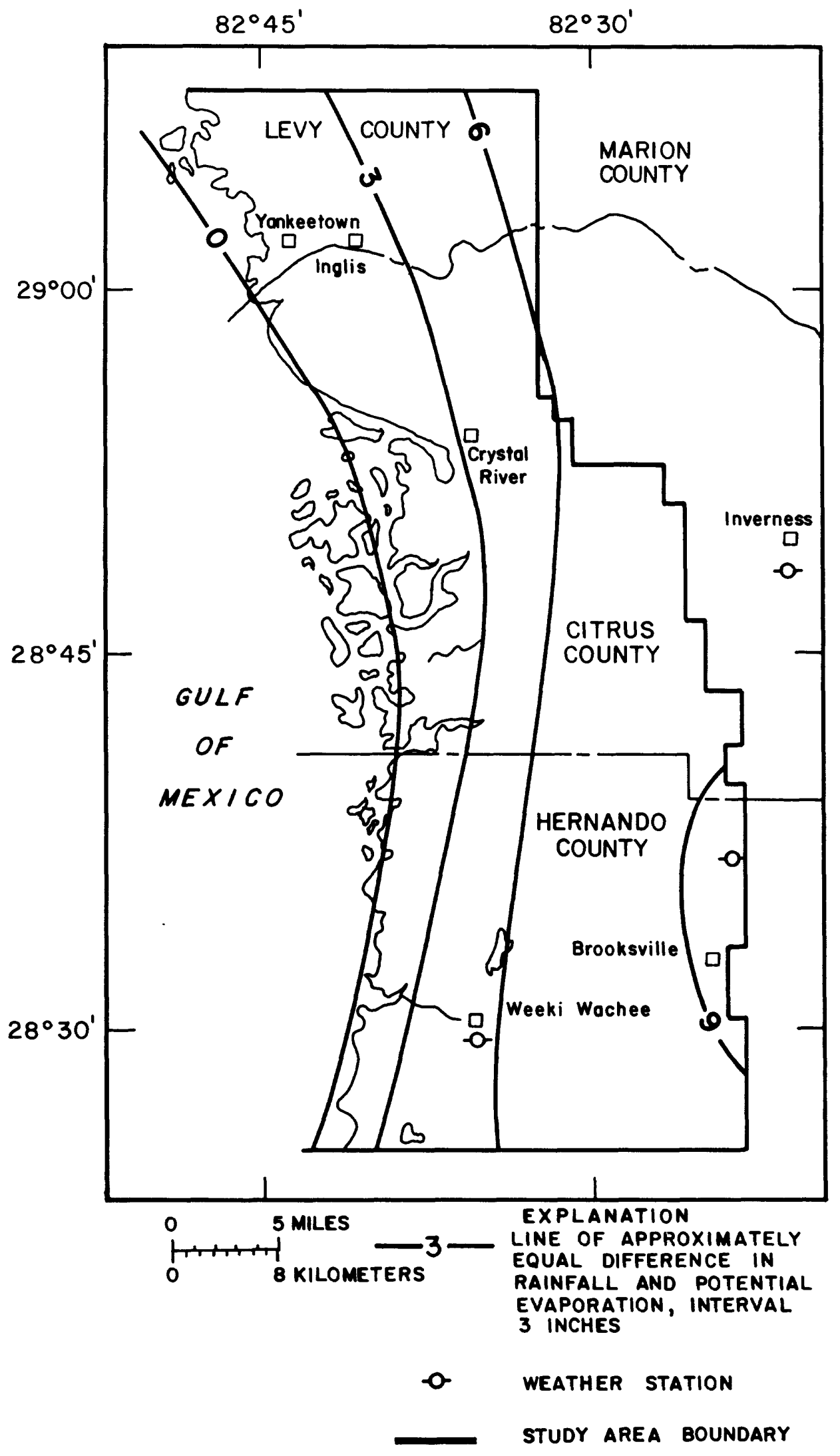

Figure 7.--Difference between rainfall and potential evaporation (modified from Visher and Hughes, 1969). 
Citrus, Hernando, and Levy Counties are underlain by a thick sequence of sedimentary rock. Solution-riddled and fractured limestone and dolomite that range in age from Eocene to Oligocene comprise the following formations in ascending order: 0ldsmar Limestone, Lake City Limestone, Avon Park Limestone, Ocala Limestone, and Suwannee Limestone. These formations generally dip from north to south. The Avon Park Limestone, the oldest rock exposed at land surface, crops out near the Withlacoochee River. The Ocala Limestone lies at or near land surface north and south of the Withlacoochee River. The Suwannee Limestone occurs above the Ocala Limestone in the southern part of Citrus County, increasing in thickness to the south through Hernando County. Sand and clays of the Alachua Formation and limestone and clays of the Hawthorn Formation fill depressions in these carbonates in some areas; mainly within the Brooksville Ridge (fig. 8). The geologic units and their water-supply properties are summarized in table 2 . Figure 8 shows relative positions and thicknesses of the geologic formations as they change from north to south. Most formational contacts are unconformable.

\section{Sinkholes}

In the study area, sinkholes vary in size from several feet to several hundred feet in diameter. A few have well-developed drainage systems. Pecks Sink, about 2.5 miles southwest of Brooksville, drains about $15 \mathrm{mi}^{2}$ through a welldeveloped stream channel (fig. 4). The channel is dry except during times of heavy rainfall. The Squirrel Prairie Sink area about 8 miles south of Brooksville drains an area of about $20 \mathrm{mi}^{2}$ of the upper reaches of the Pithlachascotee River in Pasco County to the south. Both Pecks Sink and the Squirrel Prairie Sink are hydraulically connected to the Floridan aquifer (Cherry and others, 1970). Numerous other sinkholes that have poorly developed drainage systems also exist in the area and may be hydraulically interconnected through underground channels.

\section{Occurrence of Ground Water}

A distinct surficial sand aquifer, separate from the Floridan aquifer, does not occur as a continuous unit within the study area. Some perched water-table aquifers of limited extent occur in sands in parts of the study area along the western flank of the Brooksville Ridge, along the Levy-Marion County border just north of the Withlacoochee River (Hydrogage, Inc., 1980a; 1980b), and on the west side of Hunter's Lake in Hernando County. Differences between water levels in shallow wells or surface-water bodies and the potentiometric surface of the Floridan aquifer were used as indicators of a perched water table. 


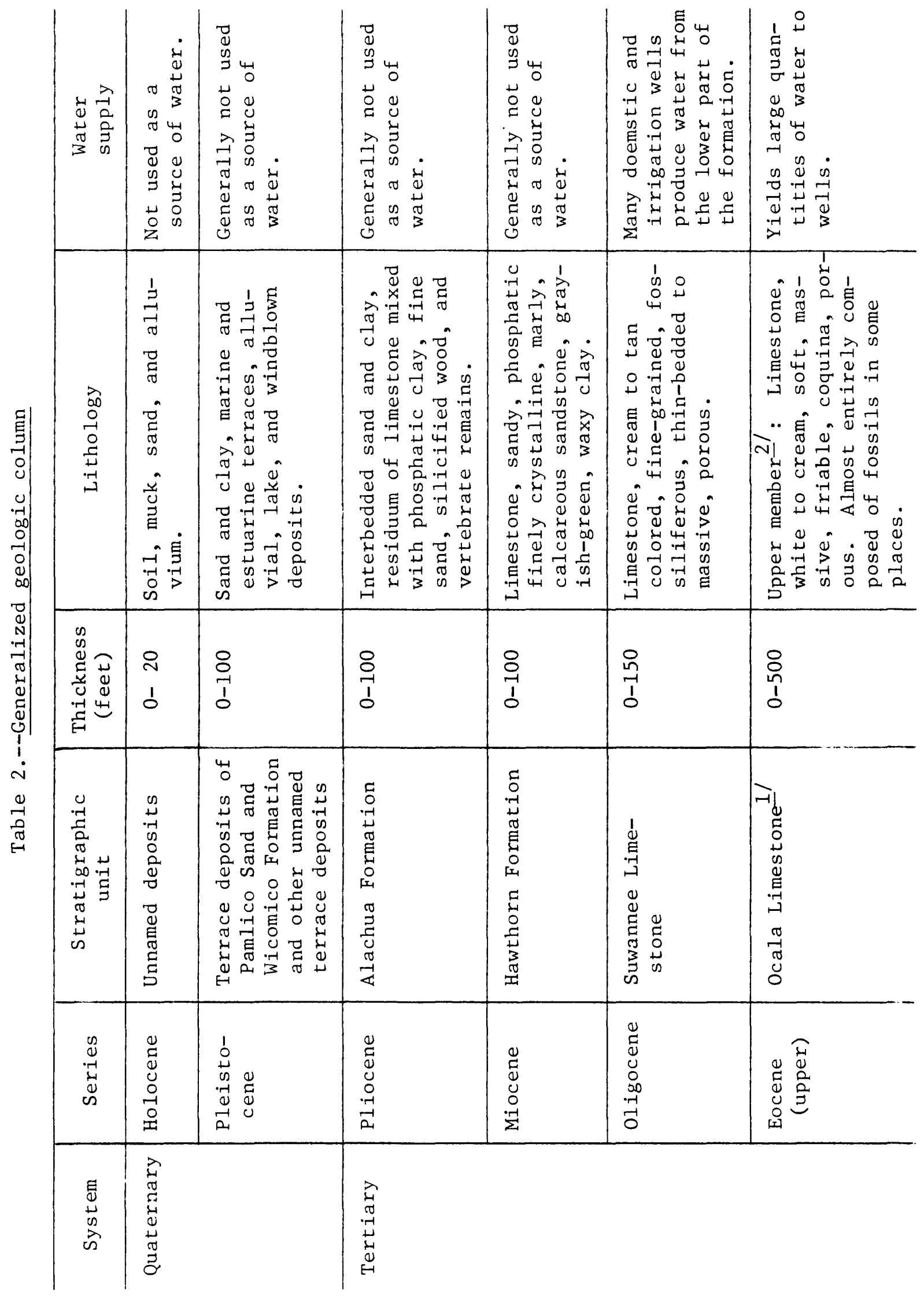




\begin{tabular}{|c|c|c|c|}
\hline & 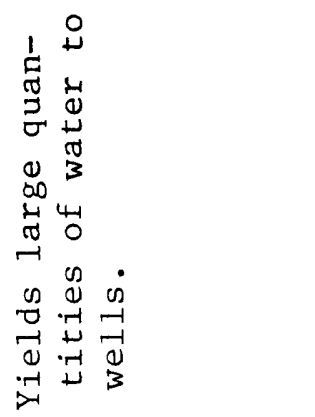 & 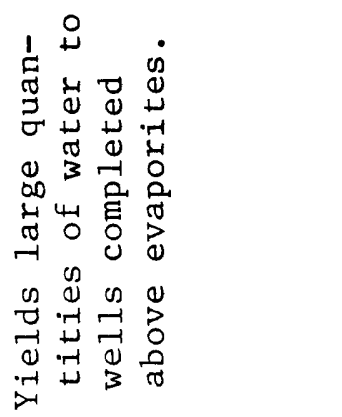 & 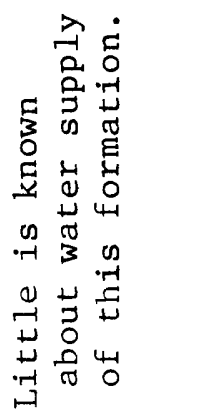 \\
\hline \multirow[t]{4}{*}{ 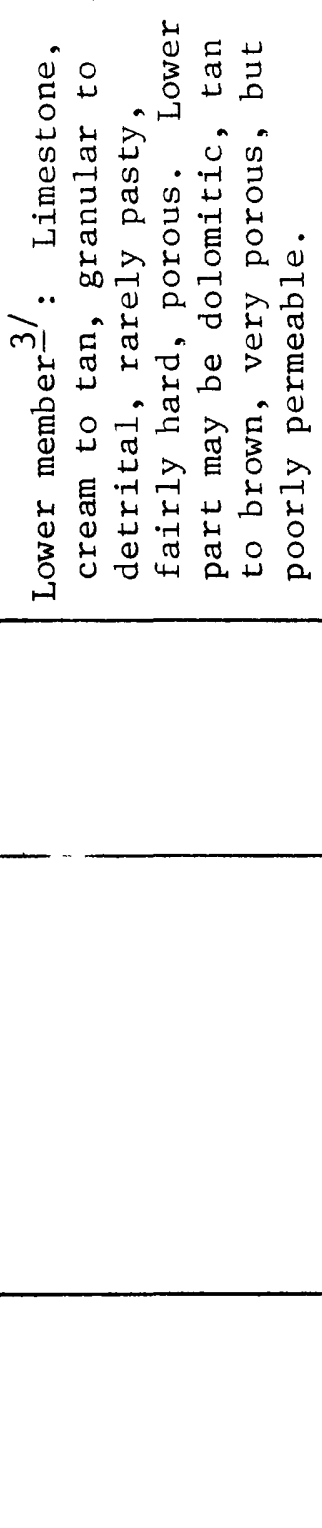 } & 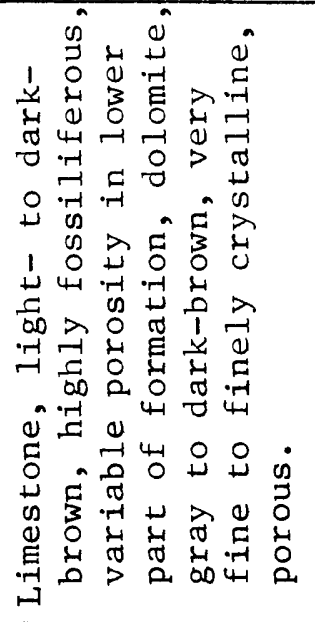 & 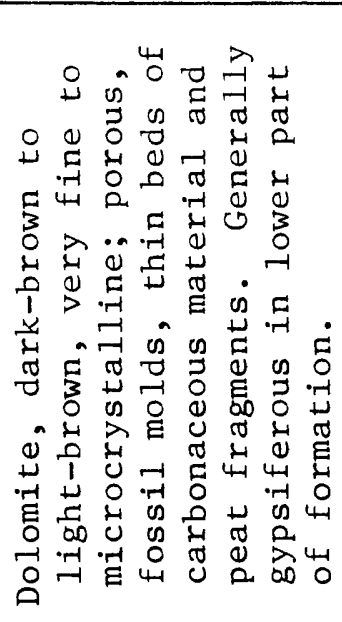 & 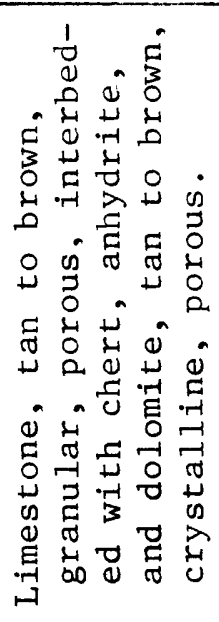 \\
\hline & $\begin{array}{l}0 \\
0 \\
+ \\
1 \\
\text { O } \\
0 \\
\text { v }\end{array}$ & $\begin{array}{l}8 \\
8 \\
\infty \\
1 \\
8 \\
0 \\
\text { n }\end{array}$ & $\begin{array}{l}8 \\
0 \\
11 \\
8 \\
0 \\
9\end{array}$ \\
\hline & 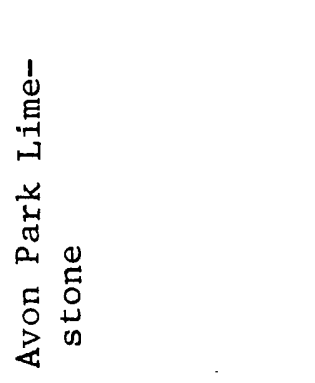 & 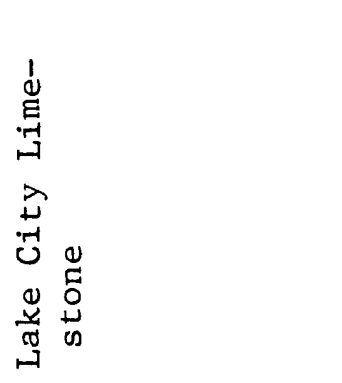 & 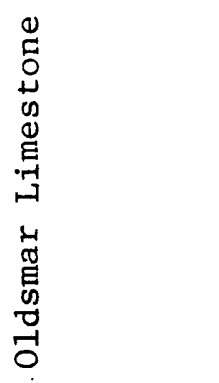 \\
\hline & \multicolumn{2}{|l|}{ 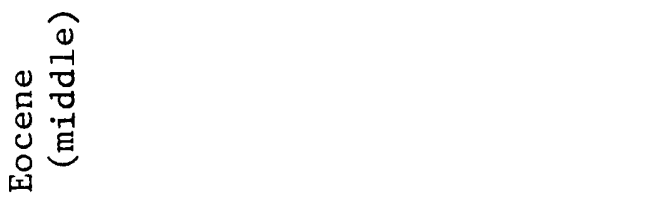 } & 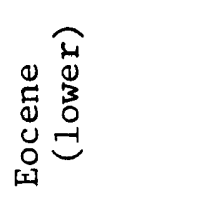 \\
\hline
\end{tabular}

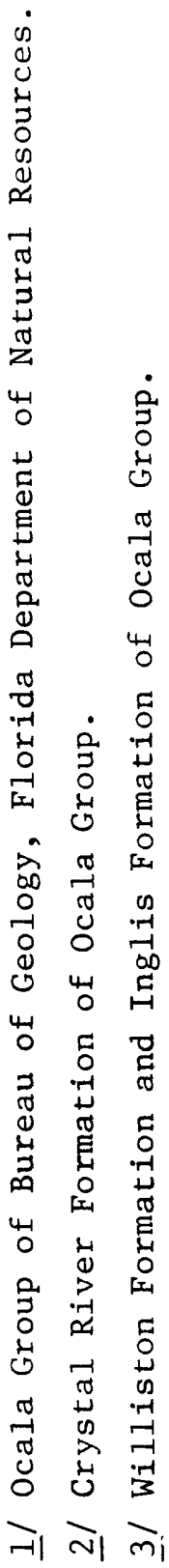




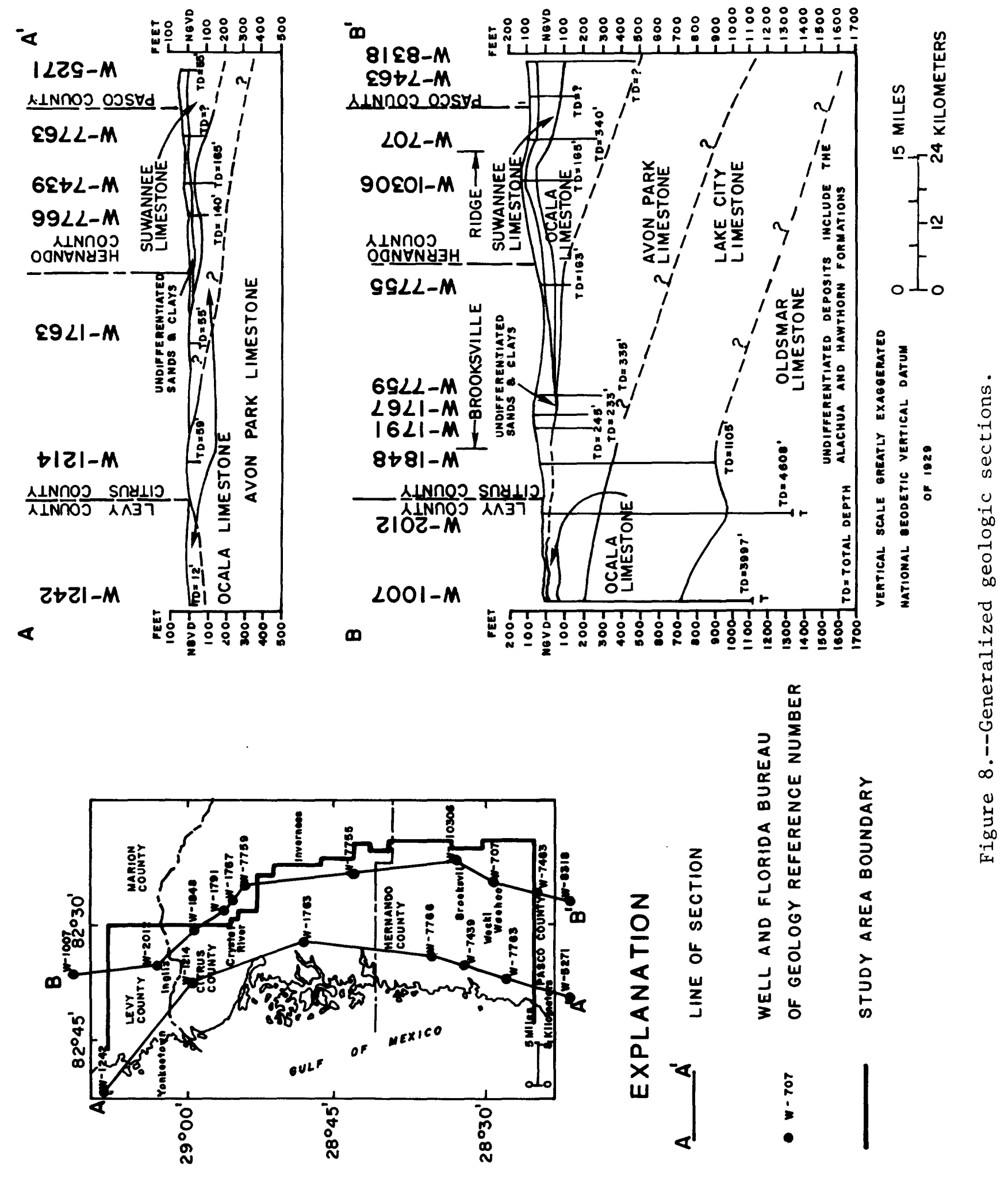


FLORIDAN AQUIFER

The principal aquifer in Florida, known as the Floridan aquifer (Parker and others, 1955), is the major source of water for domestic, agricultural, and industrial use in west-central Florida. The aquifer is composed predominantly of limestone and dolomite of Tertiary age that act as a single hydrologic unit (Parker and others, 1955). The Floridan aquifer in the study area comprises the following stratigraphic units in ascending order: the Lake City Limestone, Avon Park Limestone, and Ocala and Suwannee Limestones, where present.

The base of the Floridan aquifer is defined as that point in the aquifer where evaporites consistently fill pore spaces in the limestone and dolomite and restrict the flow of water. This generally occurs in the lower part of the Lake City Limestone in the study area. The top of the Floridan aquifer ranges from land surface near the coast to greater than 100 feet below land surface in the ridge area. Thickness of the aquifer ranges from less than 600 feet near the Withlacoochee River to almost 800 feet in southern Hernando County (Wolansky and Garbade, 1981).

Clastic sediments of sand, clay, and soil of varying thicknesses and varying degrees of permeability and some thin stringers of limestone overlie the Floridan aquifer. The Floridan is generally unconfined where these sediments are thin or missing, particularly seaward of the major springs and where clay content is relatively small compared to sand. As thickness of the clastic sedimentary layer increases, generally towards the ridge area, and as the clay content increases, vertical permeability in the sediments decreases causing local semiconfined conditions in the Floridan to exist.

\section{Hydraulic Properties}

Transmissivity is a measure of an aquifer's ability to transmit water and is usually expressed in units of feet squared per day (Lohman, 1979). Figure 9 shows locations where transmissivities have been determined by several investigators. Where pumping or aquifer tests have been performed, a point is located at the site of the pumping well. Hachured areas show where values from flow-net analyses have been used to estimate some averages. Values are given in table 3.

Transmissivities of the aquifer are high at springs and decrease away from the springs (Faulkner, 1973b). Wegki Wachee Springs has been estimated to have a transmissivity of between $1.2 \times 10^{6}$ and $2.1 \times 10^{\circ} \mathrm{ft} / \mathrm{d}$ (Sinclair, 1978). Faulkner (1973b) estimated the transmissivity of Silver Springs, about 25 miles east and slightly north of the study area, to average $2.1 \times 10^{6} \mathrm{ft}^{2} / \mathrm{d}$ and suggested that Rainbow Springs (fig. 4) probably had a similar transmissivity. Transmissivities at the other large springs are probably on the ${ }_{6}$ same order of magnitude. Ryder (1981) used a transmissivity of more than $1 \times 10^{6} \mathrm{ft} / \mathrm{d}$ for large areas surrounding major springs in a ground-water flow model of the Floridan aquifer that included the study area. The lowest reported transmissivity value is $2.0 \times 10^{4} \mathrm{ft} / \mathrm{d}$ from an aquifer test in Levy County where the confining bed is thick. 


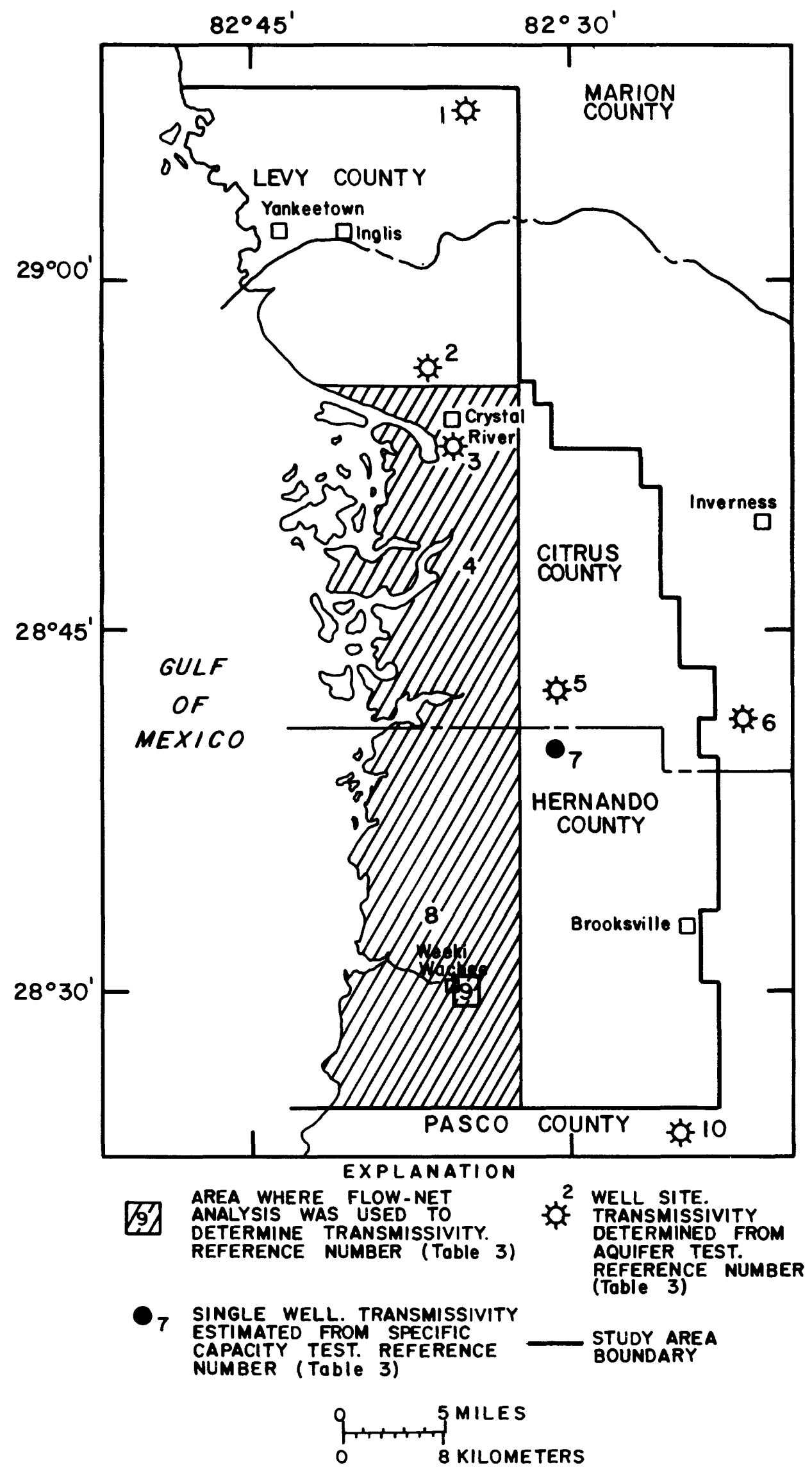

Figure 9.--Locations of aquifer-test sites. 
Table 3.--Transmissivity of the Floridan aquifer

[Locations shown on figure 9]

\begin{tabular}{|c|c|c|}
\hline $\begin{array}{l}\text { Site } \\
\text { no. }\end{array}$ & $\begin{array}{l}\text { Transmiß̧sivity } \\
\left(\mathrm{ft}^{2} / \mathrm{d}\right)\end{array}$ & Reference \\
\hline 1 & $2.0 \times 10^{4}$ & $\begin{array}{l}\text { Unpublished data in the files of the U.S. } \\
\text { Geological Survey. }\end{array}$ \\
\hline 2 & $1.2 \times 10^{6} 6^{\text {to }}$ & Geraghty and Miller, Inc. (1979). \\
\hline 3 & $1.5 \times 10^{6}$ & Seaburn and Robertson (1980a). \\
\hline 4 & $2.0 \times 10^{6}$ & Cherry and others $(1970)$ \\
\hline 5 & $\begin{array}{l}9.0 \times 10^{4} \\
2.8 \times 10^{5}\end{array}$ & Seaburn and Robertson (1980b). \\
\hline 6 & $1.2 \times 10^{6}$ & Parker (written commun., 1980). \\
\hline 7 & $9.4 \times 10^{5}$ & Estimated from unpublished data. \\
\hline 8 & $6.7 \times 10^{5}$ & Cherry and others $(1970)$ \\
\hline 9 & $\begin{array}{l}1.2 \times 10^{6} \\
2.1 \times 10^{6}\end{array}$ & Sinclair (1978, p. 17). \\
\hline 10 & $8.6 \times 10^{5}$ & $\begin{array}{l}\text { Leggette, Brashears and Graham, Inc. } \\
(1978) .\end{array}$ \\
\hline
\end{tabular}

\section{Potentiometric Surface}

The potentiometric surface of an aquifer is defined by the level to which water will rise in a tightly cased well open within the aquifer (Lohman, 1979). The regional configuration of the potentiometric surface of the upper part of the Floridan aquifer is shown on figure 10. The potentiometric highs usually represent areas of recharge or potential recharge.

The major recharge area for the Floridan aquifer in southwest Florida is in the Green Swamp area about 20 miles east of the study area where the potentiometric surface in 1980 was greater than 120 feet above sea level. Another high exists a few miles southeast of the study area in Pasco County where the potentiometric surface is 70 feet above sea level. Still another high exists within the study area in the northeast corner. Recharge to the aquifer also occurs throughout the study area, generally through highly permeable sands and sinkholes.

Ground water flows downgradient at right angles to the potentiometric lines to areas of discharge (fig. 11). Most ground water flows toward the major coastal springs from areas to the southeast, east, and northeast.

Depressions in the potentiometric surface indicate areas of discharge along streams or near springs or ground-water withdrawal sites. Re-entrant of the contour lines, an indication of discharge, occurs along the Withlacoochee River and around the major spring areas. Total discharge through springs is approximately $1,500 \mathrm{ft} / \mathrm{s}$. Seeps and upward leakage near the coast account for approximately $200 \mathrm{ft}^{3} / \mathrm{s}$ (P. D. Ryder, U.S. Geological Survey, oral commun., 1981). 


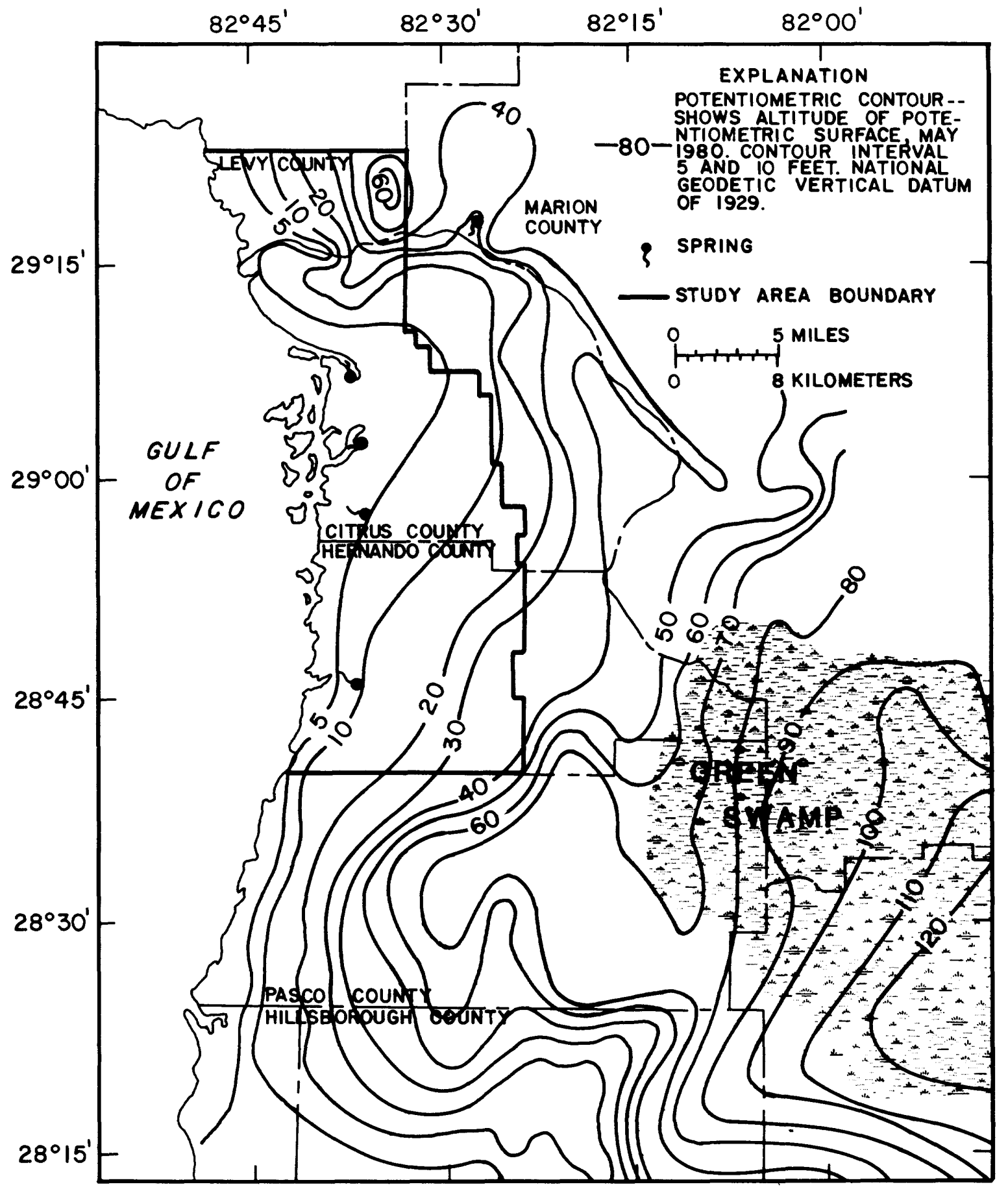

Figure 10.--Potentiometric surface of the Floridan aquifer in the study area and surrounding areas in May 1980 (from Yobbi and others, 1980a). 


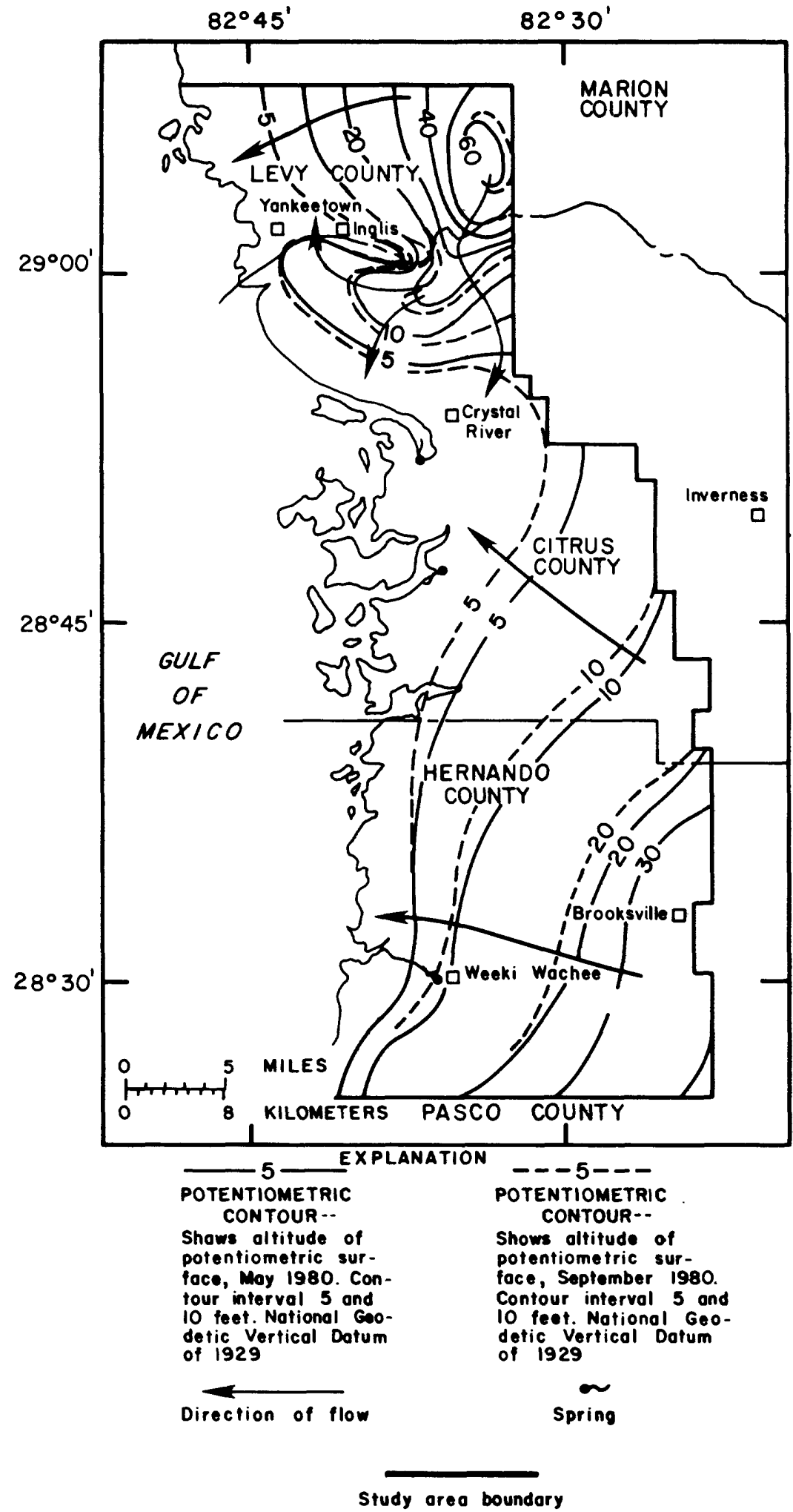

Figure 11.--Potentiometric surface of the Floridan aquifer in May and September 1980 (modified from Yobbi and others, 1980a; 1980b). 
The potentiometric surface of the Floridan aquifer changes in response to variations in rainfall and pumpage and to tidal fluctuations near the coast. Figure 11 shows the potentiometric surface for May and September 1980, the end of the dry season and end of the wet season, respectively. More stress is placed on the aquifer in May than in September because seasonal rains have not yet begun and crop irrigation is heaviest. Also, tourism is at its peak in the spring, placing additional demands on the freshwater supply. The contours of the potentiometric surface shift slightly seaward between May and September as the aquifer is recharged by summer rains and pumpage is minimal.

Hydrographs for the available period of record for seven wells (locations on fig. 12) are shown on figure 13. Seasonal fluctuations tend to be greater than annual ones, with most peaks in water level occurring in the fall. Water levels are relatively constant over the 14-year period from 1966 through 1980, although a decline in peaks seems to have occurred in wells 3 and 20 . Waterlevel peaks in 1974,1976 , and 1979 correspond with greater total annual rainfall (fig. 6). However, the peak early in 1970 at well 3 may reflect the higher than normal rainfall in 1969. Water levels are also relatively high for these same time periods--1970, 1974, 1976, and 1979--in well 20. Changes in the potentiometric surface from 1964 to 1980 indicate less than 5 feet of change in the potentiometric surfaces of the Floridan aquifer anywhere in the study area (D. K. Yobbi, U.S. Geological Survey, oral commun., 1982). The greatest decline in water level has occurred in the southeastern part of the area as is reflected in well 3. This is due in part to a decline in rainfall and possibly in part to well-field development southeast of the study area.

Along the coast, tidal changes influence water levels in wells. Tidal fluctuations are apparent in well 25 located 2.3 miles from the coast (figs. 12 and 14). Mixed semidiurnal and diurnal tidal patterns are apparent. Amplitude of the wave form is diminished as it travels inland from the shoreline. Water levels in well 20 (fig. 14), located 7.0 miles from the coast, do not show any apparent tidal influence. Table 4 lists all wells mentioned in this report along with well-identification number, depth, and casing depth.

\section{Water Use}

Ground water accounts for more than 99 percent of the $44 \mathrm{Mgal} / \mathrm{d}$ of water used for irrigation, industrial, public, and rural supply in the study area. Total pumpage varies from year to year and from season to season because of the amount and distribution of rainfall. This is especially true of pumpage for irrigation that is largest during the spring growing season when rainfall is least. As population continues to grow, pumpage for public and rural supply will increase.

The largest amount of fresh ground water withdrawn from the Floridan aquifer is used by industry. Estimated industrial use for 1980 in the study area was $32 \mathrm{Mgal} / \mathrm{d}$ (Duerr and Trommer, 1981) of which 99 percent was for rock-mining, mostly in Hernando County. 


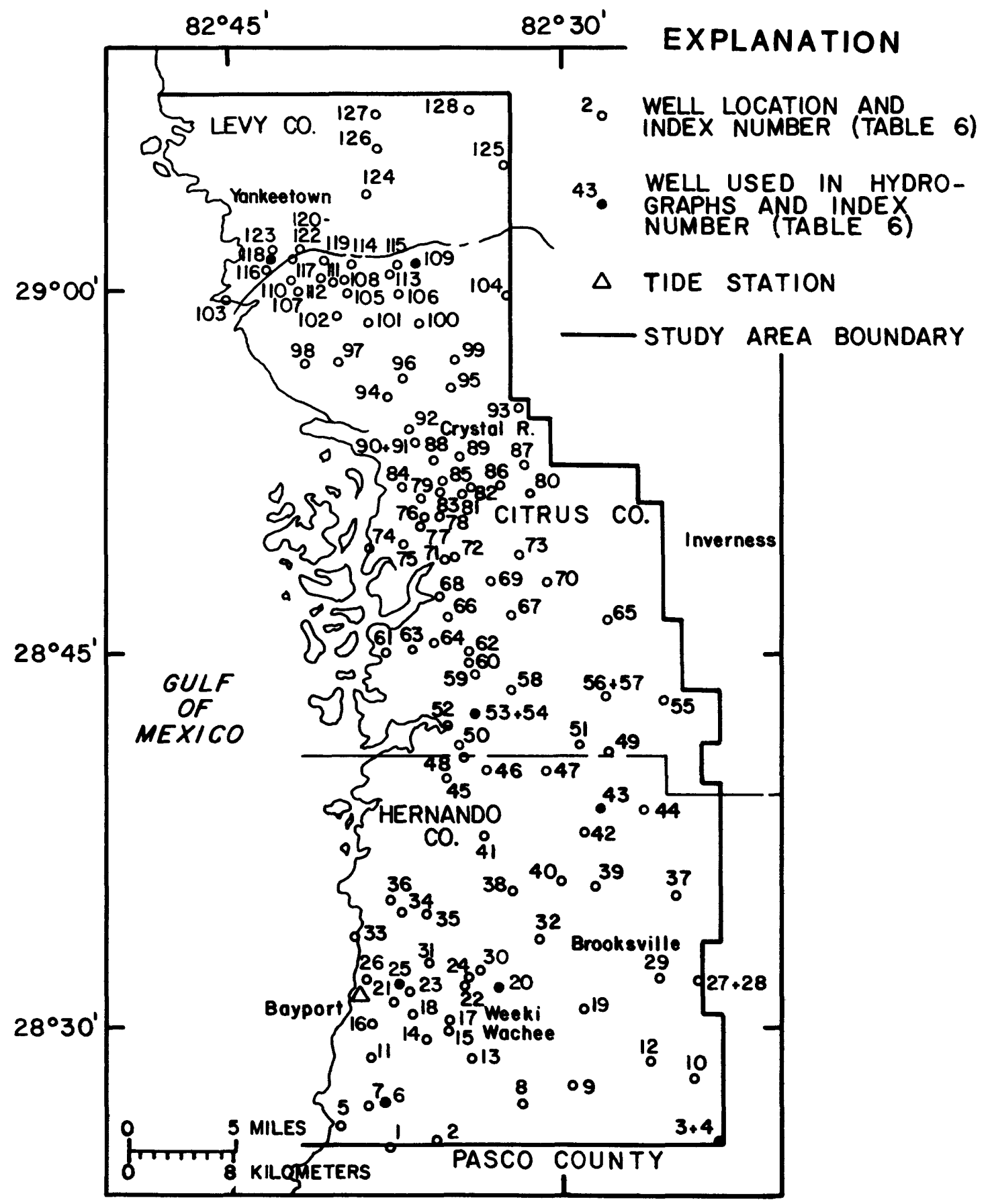

Figure 12.--Locations of wells. 

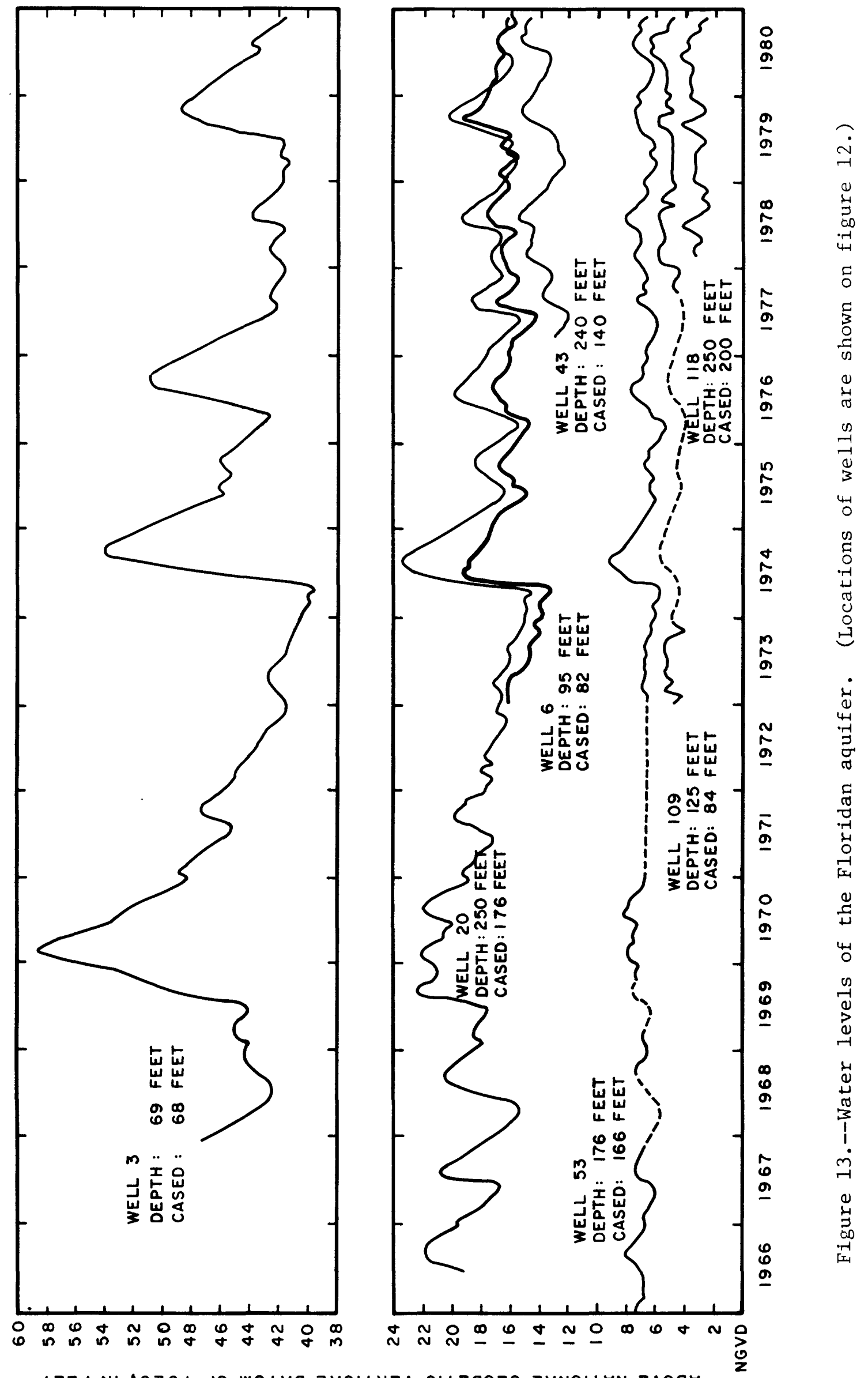

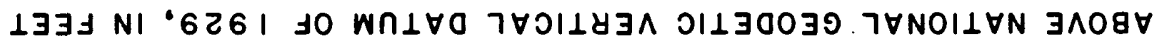

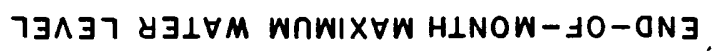




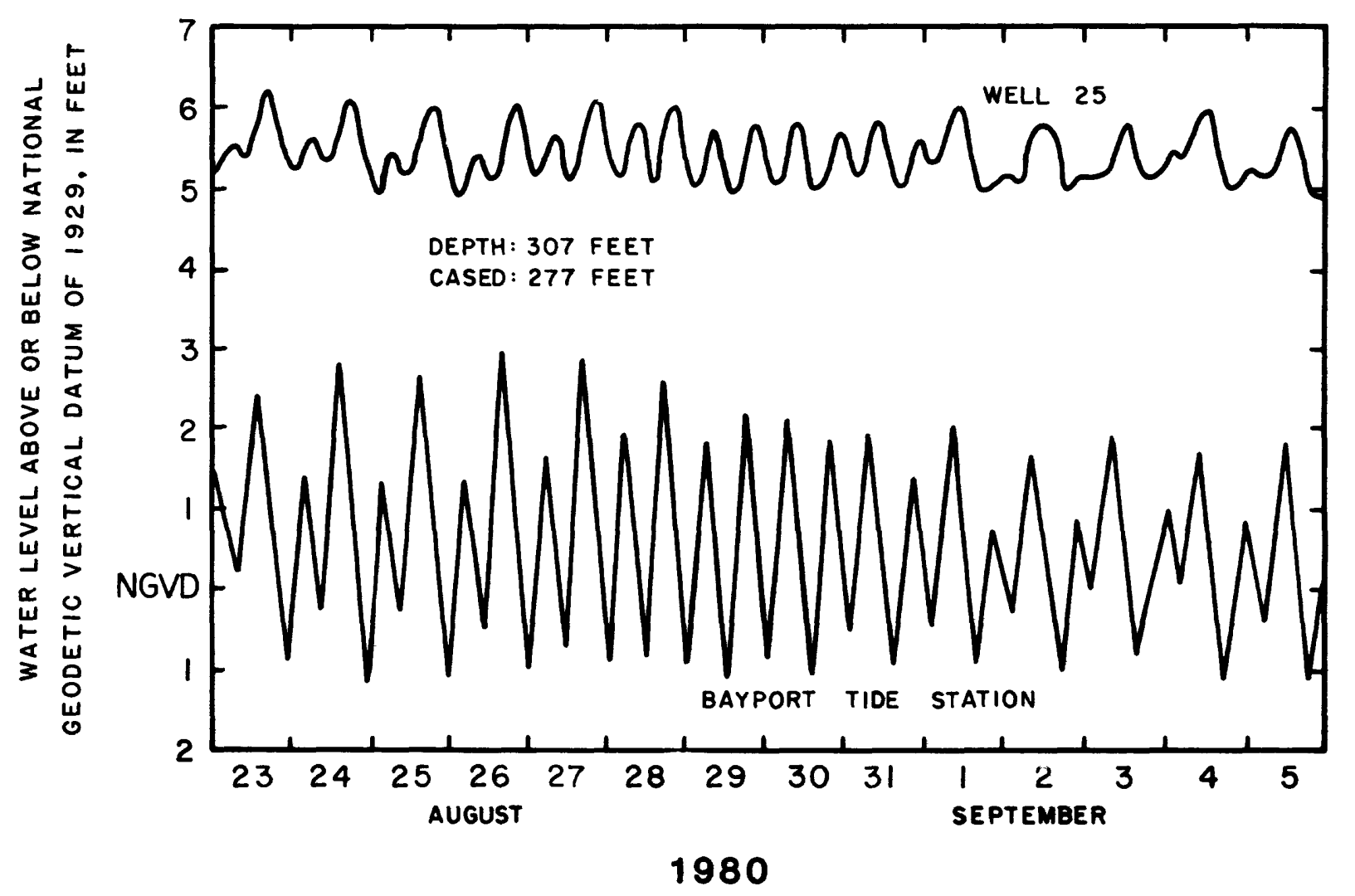

Figure 14.--Comparison of water levels in a well and tide levels. (Locations of tide station and wells are shown on figure 12.) 
Table 4.--Wells used to compile water-level and water-quality information

\begin{tabular}{|c|c|c|c|c|}
\hline $\begin{array}{l}\text { Wel1 } \\
\text { No. }\end{array}$ & $\begin{array}{c}\text { Station } \\
\text { identification }\end{array}$ & Well name & $\begin{array}{l}\text { Depth } \\
\text { of we } 11 \\
\text { (feet) }\end{array}$ & $\begin{array}{c}\text { Depth of } \\
\text { casing } \\
\text { (feet) }\end{array}$ \\
\hline 1 & 282553082370201 & Brann & 100 & - \\
\hline 2 & 282605082345801 & Romp 97 Deep & 355 & 310 \\
\hline 3 & 282636082221401 & Weeki 11 Deep & 69 & 68 \\
\hline 4 & 282636082221402 & Weeki 11 Shallow & 16 & 6 \\
\hline 5 & 282704082394301 & Aripeka 1 & 195 & 176 \\
\hline 6 & 282738082372501 & Spring Hill & 95 & 82 \\
\hline 7 & 282742082375901 & Romp TR $18-1$ & 580 & 445 \\
\hline 8 & 282756082311801 & Deltona Corp. near Springhill & 335 & 113 \\
\hline 9 & 282838082284801 & Florida Hills Memorial & 400 & - \\
\hline 10 & 282849082232201 & Altizer & 230 & - \\
\hline 11 & 282923082380301 & Hernando BH Supply & 180 & \\
\hline 12 & 282932082253301 & Imperial Estates Deep & 275 & 65 \\
\hline 13 & 282938082332001 & Deltona Corp. near Weeki Wachee & 380 & - \\
\hline 14 & 283038082352701 & River County Estates & - & - \\
\hline 15 & 283057082342901 & Holiday Inn & 315 & 62 \\
\hline 16 & 283105082380001 & Smith & 68 & \\
\hline 17 & 283108082342301 & Weeki Wachee Spring H Well & 321 & 49 \\
\hline 18 & 283127082355101 & Weeki Wachee Campground & 55 & - \\
\hline 19 & 283143082281801 & & 116 & 80 \\
\hline 20 & 283201082315601 & Weeki Wachee Well & 259 & 176 \\
\hline 21 & 283203082370201 & Presbyterian Youth Camp & 75 & 66 \\
\hline 22 & 283227082335801 & Royal Highlands No. 1 & 190 & \\
\hline 23 & 283233082364101 & & 165 & 126 \\
\hline 24 & 283240082335801 & Royal Palm Beach Deep & 245 & 217 \\
\hline 25 & 283243082365701 & Whitehurst BM, Romp TR 19-2 & 302 & 277 \\
\hline 26 & 283253082383701 & Abbott & 54 & 40 \\
\hline 27 & 283258082231901 & Brooksville \#1 & 602 & 478 \\
\hline 28 & 283258082232201 & Brooksville 非 2 & 757 & 300 \\
\hline 29 & 283259082250101 & Paff Nursery & 500 & - \\
\hline 30 & 283308082331901 & Barrett & 125 & - \\
\hline 31 & 283327082355001 & S. Hernando Sportmans Club \#2 & 101 & \\
\hline 32 & 283433082303801 & Groff & 117 & 100 \\
\hline 33 & 283433082391301 & Plummer & 33 & 32 \\
\hline 34 & 283527082365701 & Weeki Wel1 2 & 125 & 123 \\
\hline 35 & 283529082355801 & Weeki Well 3 & 140 & 133 \\
\hline 36 & 283555082372901 & Weeki Well 1 & 110 & 110 \\
\hline 37 & 283607082241501 & Seven Hills Nursery & - & - \\
\hline 38 & 283637082313301 & Padgett & 145 & 42 \\
\hline 39 & 283648082275201 & Community Church & 250 & - \\
\hline 40 & 283658082292001 & Johnston & 190 & - \\
\hline 41 & 283808082324801 & Nangel & 127 & - \\
\hline 42 & 283815082282201 & Brooksville Rock Co. Deep & 899 & 130 \\
\hline 43 & 283924082272301 & Romp Deep Well 107 & 240 & 140 \\
\hline 44 & 283940082253201 & Rivenbark & 93 & - \\
\hline 45 & 284040082342301 & Lamar Chapman Hunting Camp & & \\
\hline
\end{tabular}


Table 4.--Wells used to compile water-level and water-quality information--Continued

\begin{tabular}{|c|c|c|c|c|}
\hline $\begin{array}{l}\text { Well } \\
\text { No. }\end{array}$ & $\begin{array}{c}\text { Station } \\
\text { identification }\end{array}$ & Well name & $\begin{array}{l}\text { Depth } \\
\text { of well } \\
\text { (feet) }\end{array}$ & $\begin{array}{c}\text { Depth of } \\
\text { casing } \\
\text { (feet) }\end{array}$ \\
\hline 46 & 284048082325001 & Yellowbird & - & - \\
\hline 47 & 284102082295001 & Radke & 85 & - \\
\hline 48 & 284125082333401 & Hoppenmeyer & 218 & 216 \\
\hline 49 & 284142082272101 & Harrell & 136 & 134 \\
\hline 50 & 284144082334501 & Cason & 100 & \\
\hline 51 & 284152082281801 & Coats & 80 & - \\
\hline 52 & 284247082343201 & Strickland & & \\
\hline 53 & 284317082330601 & Chassahowitzka 1 & 176 & 166 \\
\hline 54 & 284217082330602 & Chassahowitzka 2 & 46 & 40 \\
\hline 55 & 284334082245401 & WSF-Tillis Hill Rec. Area & - & - \\
\hline 56 & 284339082270401 & Lecanto 1 & 169 & 169 \\
\hline 57 & 284339082270402 & Lecanto 2 & 41 & 36 \\
\hline 58 & 284412082313001 & Sugarmil1 Woods & 107 & 80 \\
\hline 59 & 284455082331601 & Homosassa Firetower & 138 & - \\
\hline 60 & 284501082331301 & Chassahowtizka Wildlife Refuge 1 & 140 & - \\
\hline 61 & 284532082371001 & Homosassa 1 & 45 & 39 \\
\hline 62 & 284537082331401 & Chassahowitzka Wildlife Refuge 2 & 120 & - \\
\hline 63 & 284547082361201 & Homosassa 2 & 55 & 40 \\
\hline 64 & 284551082345301 & Homosassa 3 & 99 & 82 \\
\hline 65 & 284705082270101 & Lecanto 3 & 63 & 59 \\
\hline 66 & 284720082345801 & Homosassa Special Water Dist. \#1 & & \\
\hline 67 & 284722082315001 & Memorial Gardens & 200 & - \\
\hline 68 & 284803082351701 & Norris & 50 & 44 \\
\hline 69 & 284840082325501 & Heritage Hills & - & - \\
\hline 70 & 284922082291801 & Forest Hills & 96 & 84 \\
\hline $\begin{array}{l}71 \\
72\end{array}$ & $\begin{array}{l}284938082350301 \\
284939082344701\end{array}$ & Lee - Halls - Head & $\begin{array}{l}48 \\
60\end{array}$ & \\
\hline 73 & 284947082311801 & Lecanto 4 & 46 & 34 \\
\hline 74 & 285010082384001 & Ozel1o 2 & 55 & 49 \\
\hline 75 & 285020082365301 & Ozello 3 & 41 & 39 \\
\hline 76 & 285102082361001 & Oze110 4 & 75 & 60 \\
\hline 77 & 285112082354401 & Romp TR 21-2 & 111 & - \\
\hline 78 & 285116082351401 & Ozello Water $\#_{1}$ & 100 & 70 \\
\hline 79 & 285220082361001 & Palm Springs Water & 85 & 82 \\
\hline 80 & 285229082310501 & $\begin{array}{l}\text { Lewis } \\
\text { Lewill waler }\end{array}$ & 483 & 440 \\
\hline 82 & 285234082341901 & Romp TR 21-3 Deep & 252 & 240 \\
\hline 83 & 285238082352001 & Plantation Paradise CC & 119 & 89 \\
\hline 84 & 285245082370101 & Suncoast Development Co. 5 & 33 & - \\
\hline 85 & 285248082351801 & Plantation Hotel Deep & 123 & 112 \\
\hline 86 & 285254082323001 & Lecanto 7 & 30 & 20 \\
\hline 87 & 285342082312801 & & 418 & 412 \\
\hline 88 & 285356082352801 & City of Crystal River & 152 & 100 \\
\hline 89 & 285413082343201 & Crystal River Supply Well 2 & 175 & 92 \\
\hline 90 & 285421082361601 & Crystal River Shallow & 53 & 3 \\
\hline
\end{tabular}


Table 4.--Wells used to compile water-level and water-quality information--Continued

\begin{tabular}{|c|c|c|c|c|}
\hline $\begin{array}{r}\text { Well } \\
\text { No. }\end{array}$ & $\begin{array}{c}\text { Station } \\
\text { identification }\end{array}$ & Well name & $\begin{array}{l}\text { Depth } \\
\text { of well } \\
\text { (feet) }\end{array}$ & $\begin{array}{l}\text { Depth of } \\
\text { casing } \\
\text { (feet) }\end{array}$ \\
\hline $\begin{array}{l}91 \\
92 \\
93 \\
94 \\
95\end{array}$ & $\begin{array}{l}285421082361602 \\
285508082365701 \\
285548082313801 \\
285610082374501 \\
285645082372101\end{array}$ & $\begin{array}{l}\text { Crystal River Deep } \\
\text { Indian Waters Subdiviaion No. } 1 \\
\text { Pine Ridge No. } 2 \\
\text { Lawn Ranger Nursery }\end{array}$ & $\begin{array}{r}176 \\
50 \\
150 \\
38 \\
68\end{array}$ & $\begin{array}{r}162 \\
40 \\
- \\
- \\
-\end{array}$ \\
\hline $\begin{array}{r}96 \\
97 \\
98 \\
99 \\
100\end{array}$ & $\begin{array}{l}285654082350101 \\
285737082400601 \\
285737082413001 \\
285749082342901 \\
285900082361501\end{array}$ & $\begin{array}{l}\text { Gerrits } \\
\text { FPC We11 } 3 \\
\text { FPC We11 } 2 \\
\text { US Div. of Forestry } \\
\text { Wha11 }\end{array}$ & $\begin{array}{r}88 \\
47 \\
135 \\
102\end{array}$ & $\begin{array}{l}67 \\
42 \\
- \\
-\end{array}$ \\
\hline $\begin{array}{l}101 \\
102 \\
103 \\
104 \\
105\end{array}$ & $\begin{array}{l}285918082381001 \\
285935082410901 \\
290004082454101 \\
290010082321601 \\
290023082393601\end{array}$ & $\begin{array}{l}\text { SCE } 178 \\
\text { CE } 87 \\
\text { SCE } 186 \\
\text { Dolan } \\
\text { CE } 89\end{array}$ & $\begin{array}{l}27 \\
28 \\
20 \\
82 \\
30\end{array}$ & $\begin{array}{l}- \\
20 \\
- \\
- \\
21\end{array}$ \\
\hline $\begin{array}{l}106 \\
107 \\
108 \\
109 \\
110\end{array}$ & $\begin{array}{l}290027082370701 \\
290047082414101 \\
290107082400501 \\
290112082371101 \\
290114082420901\end{array}$ & $\begin{array}{l}\text { Nichols } \\
\text { CE } 86 \\
\text { CE } 88 \\
\text { CE } 5 \\
\text { CE } 85\end{array}$ & $\begin{array}{r}78 \\
30 \\
58 \\
125 \\
24\end{array}$ & $\begin{array}{r}42 \\
8 \\
19 \\
84 \\
18\end{array}$ \\
\hline $\begin{array}{l}111 \\
112 \\
113 \\
114 \\
115\end{array}$ & $\begin{array}{l}290115082401001 \\
290117082404501 \\
290118082364101 \\
290128082392801 \\
290138082371901\end{array}$ & $\begin{array}{l}\text { SCE } 179 \text { Haven Motel } \\
\text { Cocke } \\
\text { CE } 70 \\
\text { Parcell } \\
\text { CE } 4\end{array}$ & $\begin{array}{r}40 \\
150 \\
67 \\
60 \\
64\end{array}$ & $\begin{array}{l}- \\
- \\
62 \\
28 \\
47\end{array}$ \\
\hline $\begin{array}{l}116 \\
117 \\
118 \\
119 \\
120\end{array}$ & $\begin{array}{l}290138082432001 \\
290145082421901 \\
290200082432301 \\
290202082403901 \\
290203082421301\end{array}$ & $\begin{array}{l}\text { SCE } 180 \text { Logan } \\
\text { Romp } 124 \\
\text { FPC We11 CE } 62 \\
\text { Yankeetown Well } 3\end{array}$ & $\begin{array}{r}61 \\
155 \\
59\end{array}$ & - \\
\hline $\begin{array}{l}121 \\
122 \\
123 \\
124 \\
125\end{array}$ & $\begin{array}{l}290203082421302 \\
290205082421201 \\
290220082431501 \\
290402082384901 \\
290503082323101\end{array}$ & $\begin{array}{l}\text { Yankeetown We11 非 } \\
\text { CE 3J } \\
\mathrm{T} \& \mathrm{~J} \text { Ranch }\end{array}$ & $\begin{array}{r}37 \\
115\end{array}$ & $\begin{array}{l}25 \\
-\end{array}$ \\
\hline $\begin{array}{l}126 \\
127 \\
128\end{array}$ & $\begin{array}{l}290551082380901 \\
290700082381001 \\
290745082341501\end{array}$ & $\begin{array}{l}\text { CE } 2 \\
\text { Obert } \\
\text { Tidewater } \$ 1\end{array}$ & $\begin{array}{r}32 \\
121 \\
788\end{array}$ & $\begin{array}{c}14 \\
- \\
298\end{array}$ \\
\hline
\end{tabular}


Rural water use is the second largest use of water with an estimated 6.3 Mgal/d (Duerr and Trommer, 1981). This includes domestic and livestock freshwater use. Domestic water use includes self-supplied household water and water supplied by small public-supply systems and is based on an average per capita water use of $100 \mathrm{gal} / \mathrm{d}$ per person. This does not include population served by major public-supply systems. Water used by livestock, based on livestock population, includes drinking and washing water for commercially raised animals.

Estimates for irrigation water use are based on consumptive use permitted by the Southwest Florida Water Management District and from data collected at selected sites by the U.S. Geological Survey (fig. 15). Irrigation accounted for approximately $3.9 \mathrm{Mgal} / \mathrm{d}$ of ground water withdrawn in 1980 (Duerr and Trommer, 1981).

The public-supply water-use category includes all water supplied by publicsupply systems in Crystal River, Brooksville, and Yankeetown and constitutes the smallest water-use category. In 1980, ground water used for public supply was $1.6 \mathrm{Mgal} / \mathrm{d}$.

Since 1975, the Southwest Florida Water Management District has required that all new wells 6 inches in diameter or larger or wells producing greater than $0.1 \mathrm{Mgal} / \mathrm{d}$ must have a permit to withdraw ground water for consumptive use. Consumptive use means water that will be used and not returned directly to the aquifer. The permit sets limits on average and maximum daily pumpage. The permit system was developed to protect the environment, prevent depletion of water from the aquifer, and prevent interference with nearby wells.

The distribution of permitted pumpages in the study area is shown on figure 16 (R. G. Perry, Southwest Florida Water Management District, written commun., 1980). The amounts illustrated on figure 16 represent average daily rates of permitted pumpage and do not reflect seasonal variations that may occur. Figure 16 does not include irrigation wells drilled prior to 1975 that may still be in use. However, the data presented on figure 16 can serve as a guide to locations of major stress areas. At present, most demand on the aquifer is occurring northwest of Brooksville in Hernando Count $y$.

\section{Water Quality}

Many factors affect the chemical characteristics of ground water. Ions from atmospheric precipitation will concentrate on the land surface and contribute to the mineralization of ground water through recharge. The composition and solubility of soil and rocks through which precipitation passes in the study area, however, largely determine the degree of mineralization of ground water. In coastal areas, mineralization may result from mixing of freshwater with seawater within water-bearing formations.

Chemical characteristics of ground water may influence its use. The Florida Department of State (1977) has established primary drinking-water regulations. These regulations set minimum standards for the quality of drinking water distributed by public water systems for human consumption. Primary drinking-water standards relate solely to the safety of drinking water. A list of secondary recommendations (Florida Department of State, 1977) suggests limits on certain chemical constituents that are not directly related to health, but rather to the esthetic quality of water. Criteria have also been developed for evaluating water quality for industrial and irrigation purposes (McKee and Wolf, 1963). Knowledge of the quality of water may assist in development of the resource. 


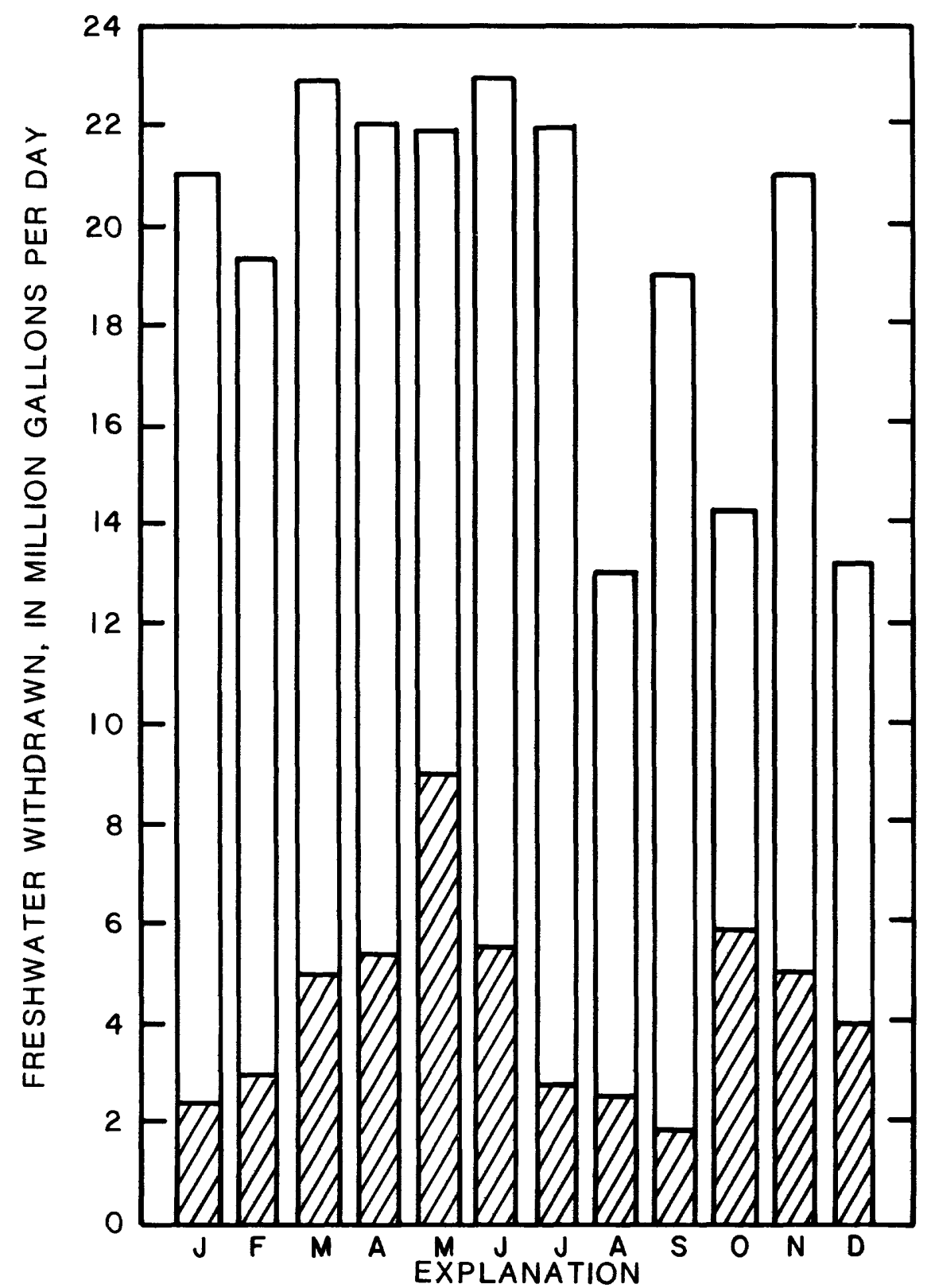

AVERAGE DAILY WITHDRAWAL, IN MILLION GALLONS PER DAY INDUSTRIAL, 100 PERCENT GROUND WATER ZIII IRRIGATION, 96 PERCENT GROUND WATER

Figure 15.--Monthly industrial and irrigation freshwater use in the study area, 1980 (A. D. Duerr, written commun., 1982). 


\section{EXPLANATION}

$\bigcirc$ pumpage center

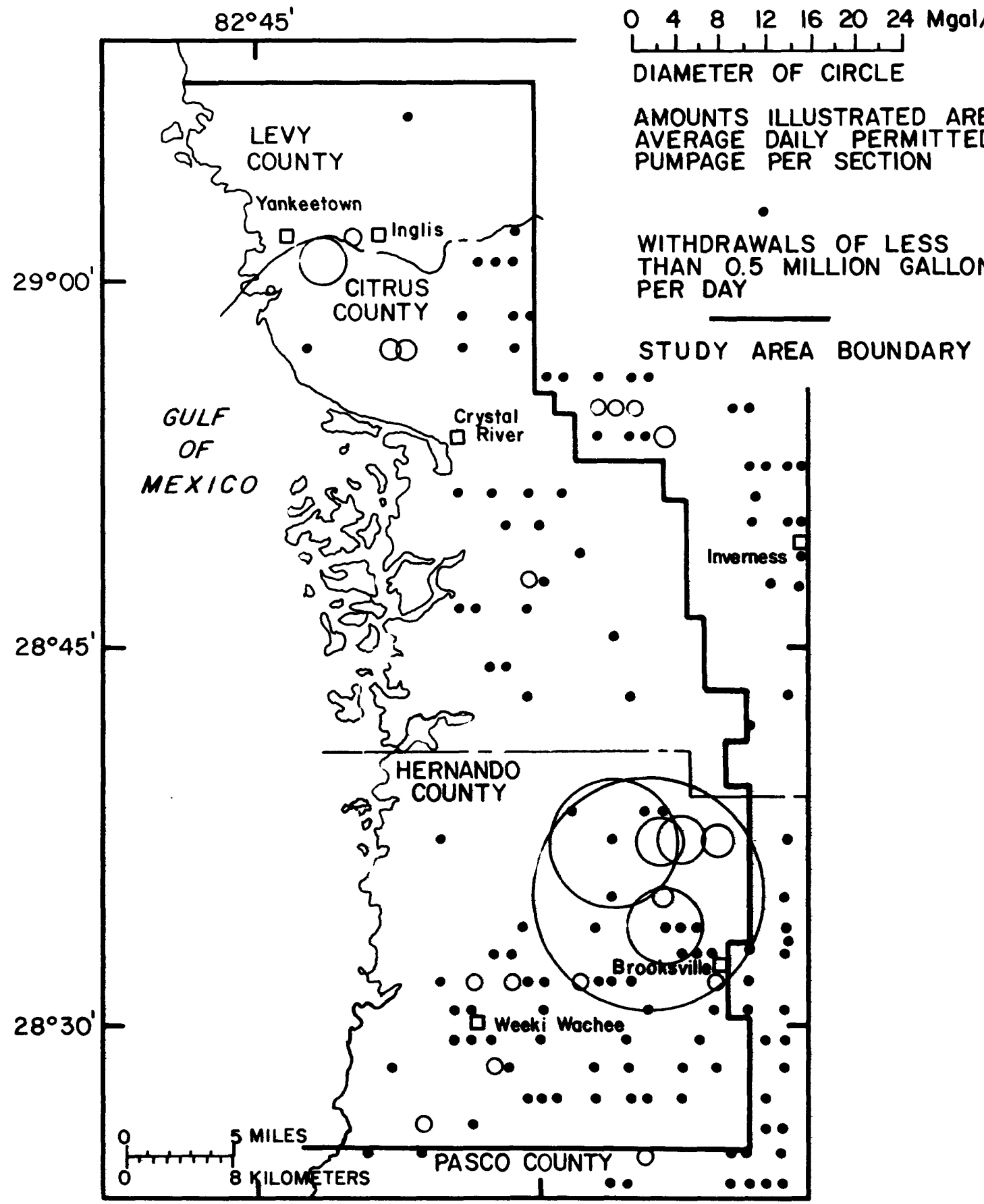

Figure 16.--Permitted daily withdrawals of ground water from the Floridan aquifer for consumptive use, 1980. 
Table 5.--Selected chemical constituents

\begin{tabular}{|c|c|c|c|c|}
\hline \multirow{2}{*}{ Constituent } & \multirow{2}{*}{ Source or cause } & \multirow{2}{*}{ Significance } & \multicolumn{2}{|c|}{$\begin{array}{l}\text { Florida Department of } \\
\text { State }(1977) \text { standards }\end{array}$} \\
\hline & & & Primary & Secondary \\
\hline $\begin{array}{l}\text { Alkalinity } \\
(\mathrm{mg} / \mathrm{L})\end{array}$ & $\begin{array}{l}\text { Caused primarily } \\
\text { by presence of } \\
\text { bicarbonate and } \\
\text { hydroxide. Borate, } \\
\text { silicate, and phos- } \\
\text { phate or other } \\
\text { weak acid radicals } \\
\text { may also contrib- } \\
\text { ute to alkalinity. }\end{array}$ & $\begin{array}{l}\text { Water with high } \\
\text { alkalinity has the } \\
\text { ability to neutra- } \\
\text { lize strong acids. }\end{array}$ & $\begin{array}{l}\text { Not estab- } \\
\text { lished. }\end{array}$ & \\
\hline $\begin{array}{l}\text { Calcium } \\
(\mathrm{mg} / \mathrm{L})\end{array}$ & $\begin{array}{l}\text { Dissolved from } \\
\text { rock materials con- } \\
\text { taining calcium } \\
\text { carbonate (lime- } \\
\text { stone, dolomite, } \\
\text { marl, and shells) } \\
\text { by water contain- } \\
\text { ing carbon dioxide. }\end{array}$ & $\begin{array}{l}\text { Calcium is the } \\
\text { principal cause of } \\
\text { hardness in water. }\end{array}$ & $\begin{array}{l}\text { Not estab- } \\
\text { lished. }\end{array}$ & \\
\hline $\begin{array}{l}\text { Chloride } \\
(\mathrm{mg} / \mathrm{L})\end{array}$ & $\begin{array}{l}\text { Dissolved from sed- } \\
\text { imentary rocks and } \\
\text { in large quanti- } \\
\text { ties from mixing } \\
\text { with seawater. } \\
\text { Present in sewage } \\
\text { and landfill leach- } \\
\text { ate. }\end{array}$ & $\begin{array}{l}\text { Chloride, when } \\
\text { present with sodi- } \\
\text { um, causes a salty } \\
\text { taste to water. }\end{array}$ & $\begin{array}{l}\text { Not estab- } \\
\text { lished. }\end{array}$ & $\leq 250$ \\
\hline $\begin{array}{l}\text { Dissolveg } \\
\text { solids } \\
(\mathrm{mg} / \mathrm{L})\end{array}$ & $\begin{array}{l}\text { Derived chiefly } \\
\text { from soil and } \\
\text { rocks as water } \\
\text { flows through an } \\
\text { aquifer. }\end{array}$ & $\begin{array}{l}\text { Dissolved solids } \\
\text { indicate the de- } \\
\text { gree of salinity } \\
\text { of water. }\end{array}$ & $\begin{array}{l}\text { Not estab- } \\
\text { lished. }\end{array}$ & \\
\hline $\begin{array}{l}\text { Fluoride } \\
(\mathrm{mg} / \mathrm{L})\end{array}$ & $\begin{array}{l}\text { Dissolved from } \\
\text { rocks and soil and } \\
\text { is found in small } \\
\text { amounts in most } \\
\text { ground water. }\end{array}$ & $\begin{array}{l}\text { Fluoride in drink- } \\
\text { ing water reduces } \\
\text { the incidence of } \\
\text { tooth deģ̧y in } \\
\text { children-. }\end{array}$ & $\begin{array}{l}\text { Not estab- } \\
\text { lished. }\end{array}$ & $\begin{array}{l}1.8 \text { (based } \\
\text { upon mean } \\
\text { air temper- } \\
\text { ature) }\end{array}$ \\
\hline
\end{tabular}

Footnotes are at end of table. 
and physical properties of water

\begin{tabular}{|c|c|c|c|c|}
\hline \multicolumn{2}{|c|}{ Range of concentration } & \multicolumn{2}{|c|}{ Median concentration } & \multirow{2}{*}{$\begin{array}{l}\text { Industrial and } \\
\text { domestic use-- }\end{array}$} \\
\hline We11s & $\begin{array}{l}\text { Springs and } \\
\text { rivers }\end{array}$ & We11s & $\begin{array}{l}\text { Springs and } \\
\text { rivers }\end{array}$ & \\
\hline $\begin{array}{c}0-810 \\
80 \text { of } 89 \text { samples: } \\
50-300\end{array}$ & $75-784$ & 130 & 130 & $\begin{array}{l}\text { Hardness and dis- } \\
\text { solved solids that } \\
\text { are usually associ- } \\
\text { ated with high alka- } \\
\text { linity can be unde- } \\
\text { sirable for certain } \\
\text { industrial and do- } \\
\text { mestic uses. }\end{array}$ \\
\hline $\begin{array}{c}4.9-418 \\
83 \text { of } 104 \text { samples: } \\
\leq 90\end{array}$ & $24-180$ & 48 & 50 & $\begin{array}{l}\text { Waters low in cal- } \\
\text { cium are desirable } \\
\text { in electroplating, } \\
\text { tanning, dyeing, } \\
\text { and in textile manu- } \\
\text { facturing. }\end{array}$ \\
\hline $\begin{array}{c}0.3-9,200 \\
89 \text { of } 101 \text { samples: } \\
\leq 25\end{array}$ & $4-6,100$ & 7 & 210 & $\begin{array}{l}\text { Large quantities may } \\
\text { affect the suitabil- } \\
\text { ity of water for in- } \\
\text { dustrial use as it } \\
\text { increases corrosive- } \\
\text { ness when combined } \\
\text { with calcium or mag- } \\
\text { nesium. It is also } \\
\text { harmful to vegeta- } \\
\text { tion when present in } \\
\text { large quantities. }\end{array}$ \\
\hline $\begin{array}{c}17-10,100 \\
3 \text { of } 96 \text { samples: } \\
>500\end{array}$ & $113-11,000$ & 177 & 555 & $\begin{array}{l}\text { Concentrations } \\
\text { greater than } 1,000 \\
\text { mg/L render water } \\
\text { unsuitable for many } \\
\text { purposes. }\end{array}$ \\
\hline $0-0.4$ & $0-1.1$ & 0.1 & 0.2 & \\
\hline
\end{tabular}


Table 5.--Selected chemical constituents and

\begin{tabular}{|c|c|c|c|c|}
\hline \multirow[t]{2}{*}{ Constituent } & \multirow{2}{*}{ Source or cause } & \multirow{2}{*}{ Significance } & \multicolumn{2}{|c|}{$\begin{array}{l}\text { Florida Department of } \\
\text { State (1977) standards }\end{array}$} \\
\hline & & & Primary & Secondary \\
\hline $\begin{array}{l}\text { Hardness } \\
(\mathrm{mg} / \mathrm{L})\end{array}$ & $\begin{array}{l}\text { Caused chiefly by } \\
\text { ions of calcium } \\
\text { and magnesium. } \\
\text { Dissolved from the } \\
\text { limestone }\left(\mathrm{CaCO}_{3}\right) \\
\text { and dolomite } \\
{\left[\mathrm{CaMg}\left(\mathrm{CO}_{3}\right)_{2}\right] \text { that }} \\
\text { compose the Flori- } \\
\text { dan aquifer. }\end{array}$ & $\begin{array}{l}\text { Classification } 4 / \\
\mathrm{mg} / \mathrm{L} \text { of } \mathrm{CaCO}_{3}: 0- \\
60, \text { soft; } 61-120, \\
\text { moderately hard; } \\
121-180 \text {, hard; } \\
>180 \text {, very hard. }\end{array}$ & $\begin{array}{l}\text { Not estab- } \\
\text { lished. }\end{array}$ & \\
\hline $\operatorname{Iron}(\mu \mathrm{g} / \mathrm{L})$ & $\begin{array}{l}\text { Dissolved from } \\
\text { many rock materi- } \\
\text { als. }\end{array}$ & $\begin{array}{l}\text { Leaves reddish- } \\
\text { brown stain. }\end{array}$ & $\begin{array}{l}\text { Not estab- } \\
\text { lished. }\end{array}$ & $\leq 300$ \\
\hline $\begin{array}{l}\text { Magnesium } \\
(\mathrm{mg} / \mathrm{L})\end{array}$ & $\begin{array}{l}\text { Dissolved princi- } \\
\text { pally from dolo- } \\
\text { mite, dolomitic } \\
\text { limestone, and gyp- } \\
\text { sum and is one of } \\
\text { the principal min- } \\
\text { eral constituents } \\
\text { of seawater. }\end{array}$ & $\begin{array}{l}\text { Causes hardness in } \\
\text { water. }\end{array}$ & $\begin{array}{l}\text { Not estab- } \\
\text { lished. }\end{array}$ & \\
\hline $\begin{array}{l}\text { Nitrogen, } \\
\text { nitrate and } \\
\text { nitrite } \\
(\mathrm{mg} / \mathrm{L})\end{array}$ & $\begin{array}{l}\text { Derived from decay- } \\
\text { ing organic matter, } \\
\text { sewage, fertili- } \\
\text { zers, and nitrates } \\
\text { in soil. Present } \\
\text { in small amounts } \\
\text { in most water. } \\
\text { Found in sewage } \\
\text { and other organic } \\
\text { wastes. }\end{array}$ & $\begin{array}{l}\text { Concentrations of } \\
\text { nitrate greater } \\
\text { than background } \\
\text { levels may suggest } \\
\text { pollution. Ni- } \\
\text { trate encourages } \\
\text { growth of algae } \\
\text { and other organ- } \\
\text { isms that produce } \\
\text { undesirable tastes } \\
\text { and odors. }\end{array}$ & $\begin{array}{l}\text { Nitrate } \\
\quad \leq 10\end{array}$ & \\
\hline $\mathrm{pH}$ (units) & $\begin{array}{l}\mathrm{pH}=\log (\mathrm{H}+) . \mathrm{Hy}- \\
\mathrm{drogen} \text { ions deriv- } \\
\text { ed from ionization } \\
\text { of acids. Caused } \\
\text { by the breakdown } \\
\text { of gases such as } \\
\mathrm{SO}_{2} \text { and } \mathrm{CO}_{2} \text { and or- } \\
\text { ganic acids. }\end{array}$ & $\begin{array}{l}\text { Indicates the acid- } \\
\text { ity or alkalinity } \\
\text { of vater: } \mathrm{pH}>7.0 \\
\text { is alkaline; } \mathrm{pH}<7.0 \\
\text { is acidic. }\end{array}$ & $\begin{array}{l}\text { Not estab- } \\
\text { lished. }\end{array}$ & Minimum 6.5 \\
\hline
\end{tabular}




\begin{tabular}{|c|c|c|c|c|}
\hline \multicolumn{2}{|c|}{ Range of concentration } & \multicolumn{2}{|c|}{ Median concentration } & \multirow{2}{*}{$\begin{array}{l}\text { Industrial and } \\
\text { domestic use- }\end{array}$} \\
\hline Wells & $\begin{array}{l}\text { Springs and } \\
\text { rivers }\end{array}$ & Wells & $\begin{array}{l}\text { Springs and } \\
\text { rivers }\end{array}$ & \\
\hline $\begin{array}{c}13-2,000 \\
8 \text { of } 101 \text { samples: } \\
>300\end{array}$ & $96-2,100$ & 158 & 215 & $\begin{array}{l}\text { Forms scale in boil- } \\
\text { ers, water heaters, } \\
\text { and pipes. Consumes } \\
\text { soap before a lather } \\
\text { can form. }\end{array}$ \\
\hline $0-180,000$ & $0-3,300$ & 30 & 10 & $\begin{array}{l}\text { Water high in iron } \\
\text { is objectionable for } \\
\text { food processing, } \\
\text { textile processing, } \\
\text { beverages, ice manu- } \\
\text { facturing, brewing, } \\
\text { and other processes. }\end{array}$ \\
\hline $0.1-590$ & $\begin{array}{c}2.4-400 \\
3 \text { of } 21 \text { samples: }\end{array}$ & 5.3 & 22.0 & $\begin{array}{l}\text { Water having low } \\
\text { magnesium and calci- } \\
\text { um concentrations is } \\
\text { desirable for elec- } \\
\text { troplating, tanning, } \\
\text { dyeing, and textile } \\
\text { manufacturing. }\end{array}$ \\
\hline $\begin{array}{c}\mathrm{NO}_{2}+\mathrm{NO}_{3} \\
0-2.9\end{array}$ & $\begin{array}{c}\mathrm{NO}_{2}+\mathrm{NO}_{3} \\
0-7.2\end{array}$ & 0.06 & 0.10 & $\begin{array}{l}\text { Nitrite is undesira- } \\
\text { ble in water for } \\
\text { some dyeing and } \\
\text { brewing processes. }\end{array}$ \\
\hline $6.5-8.5$ & $5.5-8.5$ & 7.6 & 7.7 & $\begin{array}{l}\text { Corrosiveness of wa- } \\
\text { ter generally in- } \\
\text { creases with decreas- } \\
\text { ing } \mathrm{pH} \text {. }\end{array}$ \\
\hline
\end{tabular}


Table 5.--Selected chemical constituents and

\begin{tabular}{|c|c|c|c|c|}
\hline \multirow[t]{2}{*}{ Constituent } & \multirow{2}{*}{ Source or cause } & \multirow{2}{*}{ Significance } & \multicolumn{2}{|c|}{$\begin{array}{l}\text { Florida Department of } \\
\text { State (1977) standards }\end{array}$} \\
\hline & & & Primary & Secondary \\
\hline $\begin{array}{l}\text { Phosphorus } 5 / \\
(\mathrm{mg} / \mathrm{L})\end{array}$ & $\begin{array}{l}\text { Prevalent in na- } \\
\text { ture in organic } \\
\text { forms. Results } \\
\text { from leaching of } \\
\text { soil and from fer- } \\
\text { tilizer, decomposi- } \\
\text { tion of plants and } \\
\text { animals, sewage, } \\
\text { and industrial } \\
\text { wastes. }\end{array}$ & $\begin{array}{l}\text { Stimulates growth } \\
\text { of algae which can } \\
\text { result in odor and } \\
\text { filtration prob- } \\
\text { lems. } \\
\end{array}$ & $\begin{array}{l}\text { Not estab- } \\
\text { lished. }\end{array}$ & \\
\hline $\begin{array}{l}\text { Radionuc- } \\
\text { lides } \\
(\mathrm{pCi} / \mathrm{L})\end{array}$ & $\begin{array}{l}\text { Decay of radioac- } \\
\text { tive elements, } \\
\text { either naturaily } \\
\text { occurring or man- } \\
\text { made. }\end{array}$ & $\begin{array}{l}\text { Radium- } 226 \text { is fre- } \\
\text { quently found in } \\
\text { ground water asso- } \\
\text { ciated with phos- } \\
\text { phate ore. Manmade } \\
\text { is associated with } \\
\text { fallout from nuc- } \\
\text { lear weapons test- } \\
\text { ing. Levels may be } \\
\text { increased by small } \\
\text { releases from nuc- } \\
\text { lear facilities. }\end{array}$ & $\begin{array}{l}\text { Gross alpha } \\
\leq 15\end{array}$ & $\begin{array}{l}\text { Gross alpha } \\
\quad \leq 0.5 \\
\text { Gross beta } 6 / \\
\quad \leq 5.0\end{array}$ \\
\hline $\begin{array}{l}\text { Silica } \\
(\mathrm{mg} / \mathrm{L})\end{array}$ & $\begin{array}{l}\text { Derived from decom- } \\
\text { position and meta- } \\
\text { morphosis of sili- } \\
\text { cate minerals ra- } \\
\text { ther than from the } \\
\text { solution of quartz. }\end{array}$ & & $\begin{array}{l}\text { Not estab- } \\
\text { lished. }\end{array}$ & \\
\hline $\begin{array}{l}\text { Sodium and } \\
\text { potassium } \\
(\mathrm{mg} / \mathrm{L})\end{array}$ & $\begin{array}{l}\text { Dissolved from } \\
\text { most rock mater- } \\
\text { ials and are nor- } \\
\text { mally found in } \\
\text { small amounts in } \\
\text { ground water. }\end{array}$ & $\begin{array}{l}\text { High concentration } \\
\text { in seawater. }\end{array}$ & $\begin{array}{l}\text { Not estab- } \\
\text { lished. }\end{array}$ & \\
\hline $\begin{array}{l}\text { Specific } \\
\text { conductance } \\
\text { ( } \mu \text { mho) }\end{array}$ & $\begin{array}{l}\text { Measure of water's } \\
\text { ability to conduct } \\
\text { an electric cur- } \\
\text { rent. The conduc- } \\
\text { tance is facilitat- } \\
\text { ed by free ions as- } \\
\text { sociated with dis- } \\
\text { solved constitu- } \\
\text { ents. }\end{array}$ & $\begin{array}{l}\text { Specific conduc- } \\
\text { tance is generally } \\
\text { proportional to } \\
\text { total dissolved } \\
\text { solids. } \\
\end{array}$ & $\begin{array}{l}\text { Not estab- } \\
\text { lished. }\end{array}$ & \\
\hline
\end{tabular}


physical properties of water--Continued

\begin{tabular}{|c|c|c|c|c|}
\hline \multicolumn{2}{|c|}{ Range of concentration } & \multicolumn{2}{|c|}{ Median concentration } & \multirow{2}{*}{$\begin{array}{l}\text { Industrial and } \\
\text { domestic use }\end{array}$} \\
\hline Wells & $\begin{array}{l}\text { Springs and } \\
\text { rivers }\end{array}$ & Wells & $\begin{array}{l}\text { Springs and } \\
\text { rivers }\end{array}$ & \\
\hline $\begin{array}{l}0-0.5 \\
\text { samples: } \\
>0.1\end{array}$ & $\begin{array}{l}0-0.12 \\
\text { (orthophos- } \\
\text { phate) }\end{array}$ & 0.01 & 0.02 & \\
\hline $\begin{array}{l}\text { Gross alpha } \\
\quad 1.4-11 \\
\text { Gross beta } \\
<1.8-16\end{array}$ & & & & \\
\hline $\begin{array}{l}0.1-33 \\
94 \text { of } 101 \text { samp- } \\
\text { les: } \leq 10\end{array}$ & $\begin{array}{l}0.7-64 \\
3 \text { of } 21 \text { samp- } \\
\text { les: >10 }\end{array}$ & 6.6 & 8.0 & $\begin{array}{l}\text { Undesirable for } \\
\text { boiler water. Forms } \\
\text { a hard coating on } \\
\text { steam-turbine } \\
\text { blades. }\end{array}$ \\
\hline $\begin{array}{l}\text { Sodium } \\
1.6-4,200 \\
\text { Potassium } \\
0-180\end{array}$ & $\begin{array}{l}\text { Sodium } \\
1.2-3,500 \\
\text { Potassium } \\
0-150\end{array}$ & \begin{tabular}{|} 
Sodium \\
4.7 \\
Potassium \\
0.3
\end{tabular} & $\begin{array}{c}\text { Sodium } \\
120 \\
\text { Potassium } \\
4.7\end{array}$ & $\begin{array}{l}\text { If sodium content is } \\
\text { much higher than } 100 \\
\text { mg/L, it may cause } \\
\text { foaming in steam } \\
\text { boilers. }\end{array}$ \\
\hline $1-26,600$ & $186-19,000$ & 386 & 755 & \\
\hline
\end{tabular}


Table 5.--Selected chemical constituents and

\begin{tabular}{|c|c|c|c|c|}
\hline \multirow{2}{*}{ Constituent } & \multirow{2}{*}{ Source or cause } & \multirow{2}{*}{ Significance } & \multicolumn{2}{|c|}{$\begin{array}{l}\text { Florida Department of } \\
\text { State (1977) standards }\end{array}$} \\
\hline & & & Primary & Secondary \\
\hline $\begin{array}{l}\text { Strontium } \\
(\mu \mathrm{g} / \mathrm{L})\end{array}$ & $\begin{array}{l}\text { Occurs in water } \\
\text { where strontium } \\
\text { containing miner- } \\
\text { als are present. }\end{array}$ & $\begin{array}{l}\text { It adds to the } \\
\text { hardness of the } \\
\text { water. }\end{array}$ & $\begin{array}{l}\text { Not estab- } \\
\text { lished. }\end{array}$ & \\
\hline $\begin{array}{l}\text { Sulfate } \\
(\mathrm{mg} / \mathrm{L})\end{array}$ & $\begin{array}{l}\text { Dissolved from } \\
\text { rocks containing } \\
\text { gypsum, iron sul- } \\
\text { fide, and other } \\
\text { sulfur compounds. }\end{array}$ & $\begin{array}{l}\text { Third most common } \\
\text { constituent of sea- } \\
\text { water. May give } \\
\text { bitter taste to } \\
\text { water and may pro- } \\
\text { duce undesirable } \\
\text { laxative effects. }\end{array}$ & $\begin{array}{l}\text { Not estab- } \\
\text { lished. }\end{array}$ & $\leq 250$ \\
\hline $\begin{array}{l}\text { Temperature } \\
\left({ }^{\circ} \mathrm{C}\right) \underline{I} /\end{array}$ & $\begin{array}{l}\text { Solar energy, heat } \\
\text { from the Earth's } \\
\text { core, and thermal } \\
\text { loading from waste } \\
\text { outfalls. }\end{array}$ & $\begin{array}{l}\text { Affects usefulness } \\
\text { of water for many } \\
\text { purposes. }\end{array}$ & $\begin{array}{l}\text { Not estab- } \\
\text { lished. }\end{array}$ & \\
\hline
\end{tabular}

1/ McKee and Wolf, 1963.

2/ Dissolved solids are approximately equal to 0.52 times the specific conductance.

3/ Dean and others, 1942.

4/ Hem, 1970.

5/ Dissolved phosphorus is generally sampled for in ground water. The more specific oxided form of phosphorus, orthophosphorus, is generally. sampled for in surface water.

6/ National Academy of Science and National Academy of Engineering, 1973.

7/ Shallow wells generally yield water that is near the mean annual air temperature of the area. In deep wells, the temperature increases on the average about $1^{\circ} \mathrm{C}$ per foot of depth.

The recommended limits for selected chemical constituents and physical properties of water for public water supplies and for some industrial and agricultural uses are listed in table 5 .

Chemical analyses were made of water from 63 selected wells and one spring during this study. Wells selected for analysis ranged in depth from 20 to 899 feet and were distributed areally within the study area. Results of analyses from the 63 wells and the spring and from previous samplings at these and additional wells, springs, and spring-fed rivers are listed in tables 6 and 7 . 


\begin{tabular}{|c|c|c|c|c|}
\hline \multicolumn{2}{|c|}{ Range of concentration } & \multicolumn{2}{|c|}{ Median concentration } & \multirow{2}{*}{$\begin{array}{l}\text { Industrial and } \\
\text { domestic use }\end{array}$} \\
\hline We11s & $\begin{array}{l}\text { Springs and } \\
\text { rivers }\end{array}$ & We11s & $\begin{array}{l}\text { Springs and } \\
\text { rivers }\end{array}$ & \\
\hline $\begin{array}{c}1-7,280 \\
\text { Most samples: } \\
<1,000\end{array}$ & $60-4,800$ & 150 & 270 & \\
\hline $\begin{array}{l}0-1,100 \\
92 \text { of } 98 \text { samp- } \\
\text { les: } \quad<30\end{array}$ & $2.1-830$ & 7.1 & 35 & $\begin{array}{l}\text { Some calcium sulfate } \\
\text { beneficial to beer } \\
\text { brewing process. } \\
\text { May contribute to } \\
\text { boiler scale. }\end{array}$ \\
\hline $21.0-28.0$ & $21.0-29.0$ & 24.0 & 24.0 & $\begin{array}{l}\text { For most purposes, } \\
\text { water of uniformly } \\
\text { low temperature is } \\
\text { desired. }\end{array}$ \\
\hline
\end{tabular}

Water is generally of good quality for most purposes except near the coast where the transition from seawater to freshwater occurs. Stiff diagrams depict the quality of water from representative wells (fig. 17). Inland wells are of the calcium bicarbonate type. Several wells near the coast (we11s 33, 77, and 103) have a significant amount of sodium and chloride due to the presence of seawater. In the set of wells $(33,35$, and 39) from the coast inland, the transition from sodium chloride type to calcium bicarbonate type can be seen.

Ground-water quality in the vicinity of the Withlacoochee River may be altered by the river in areas where it recharges the aquifer, which results in lower amounts of dissolved constituents, for instance, near Lake Rousseau. Generally, dissolved constituents in the river are less than in the aquifer. During periods of low flow at most places along the river, concentrations of most chemical constituents may increase because of ground-water inflow.

Water-quality zones shown on figures 18 through 21 were constructed from point data and represent the quality of water at 100 feet below land surface. Most data used to construct the maps were collected in May 1980; however, data obtained between 1966 and 1980 were also used where 1980 data were not available. This is justified by the fact that concentrations of most chemical constituents remained relatively constant from year to year. 

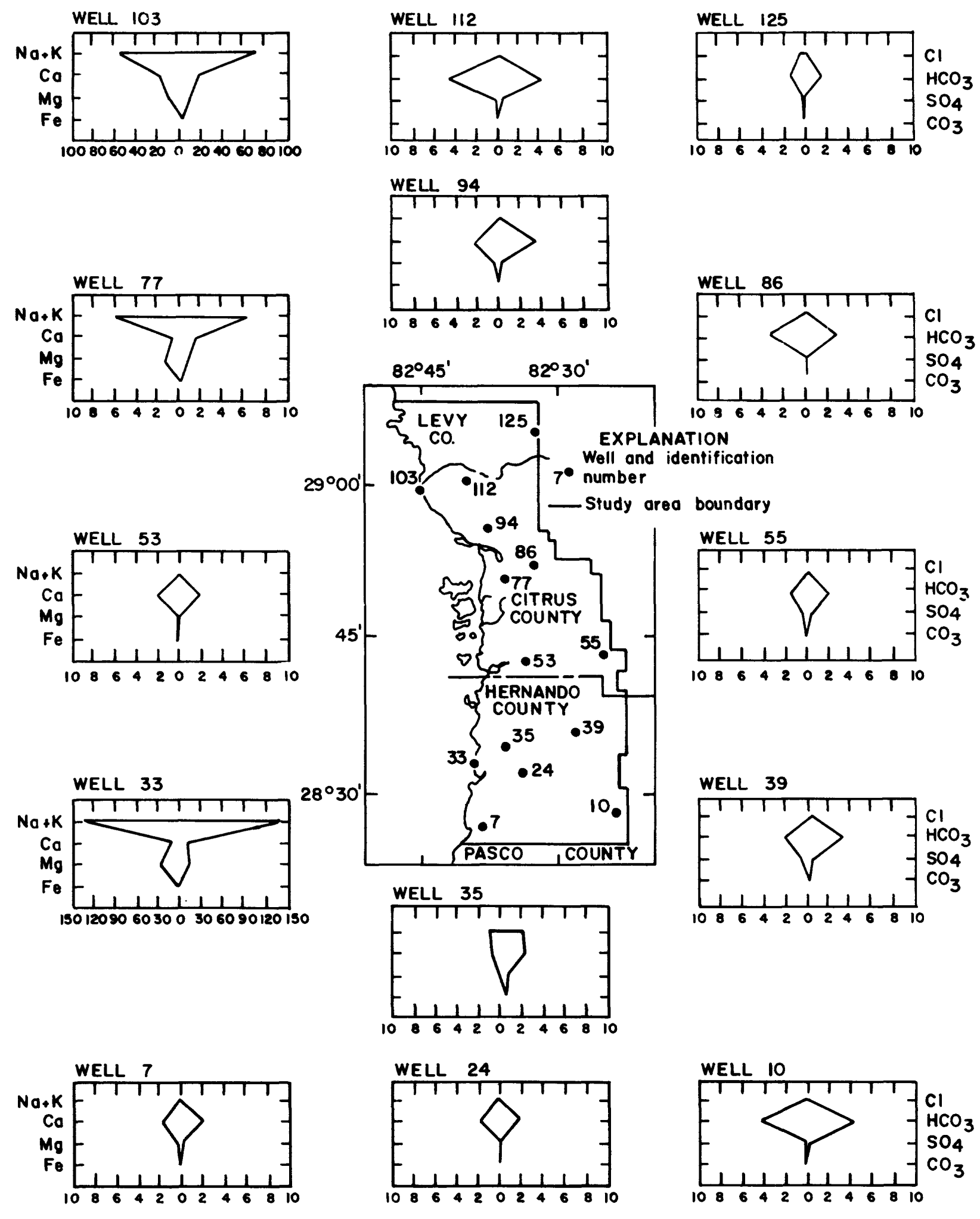

CATIONS

ANIONS

MILLIEQUIVALENTS PER LITER

Figure 17.--Concentrations of major constituents in water from wells. 


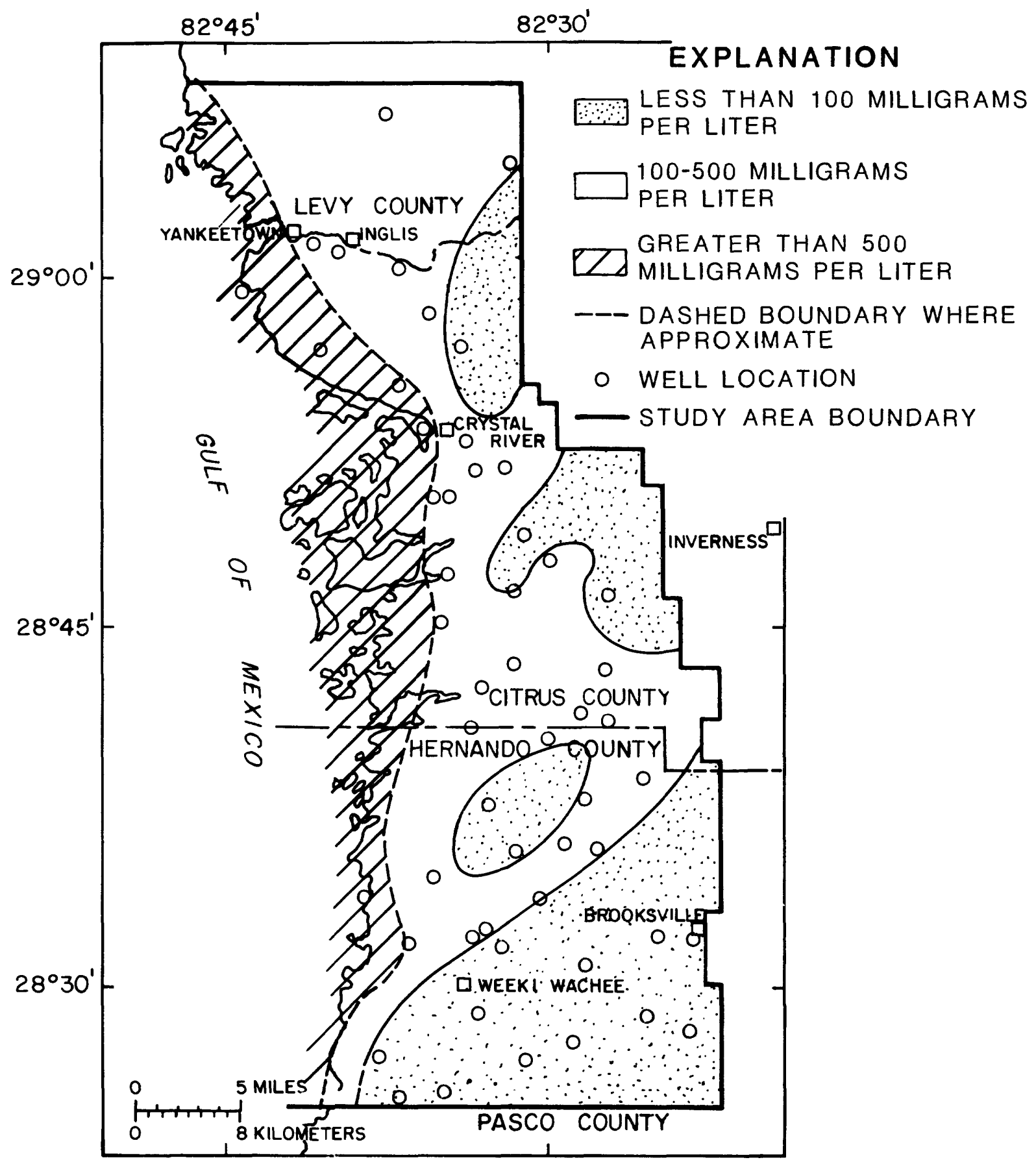

Figure 18.--Distribution of dissolved solids in ground water at a depth of 100 feet below land surface. 


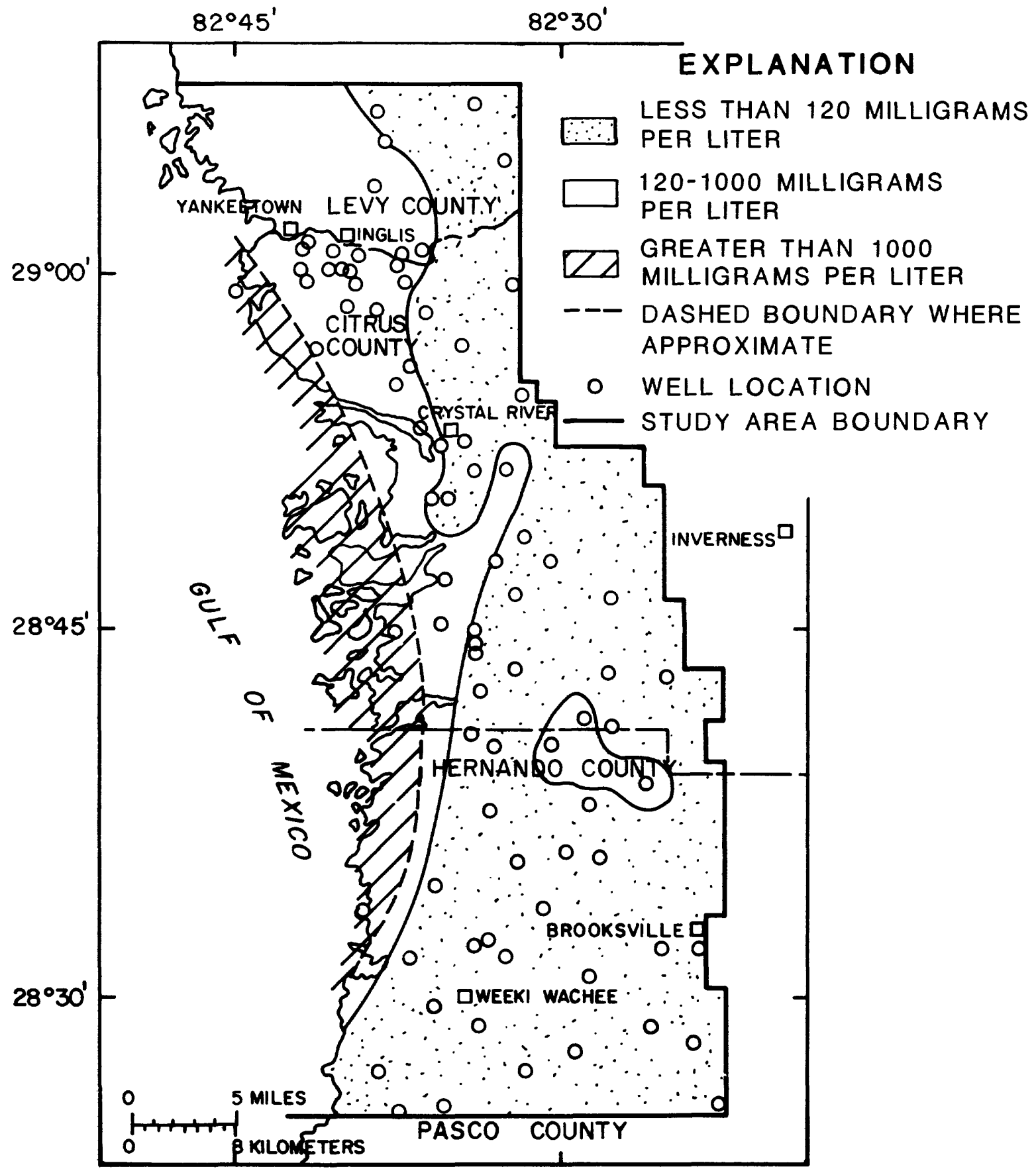

Figure 19.--Distribution of carbonate hardness in ground water at a depth of 100 feet below land surface. 


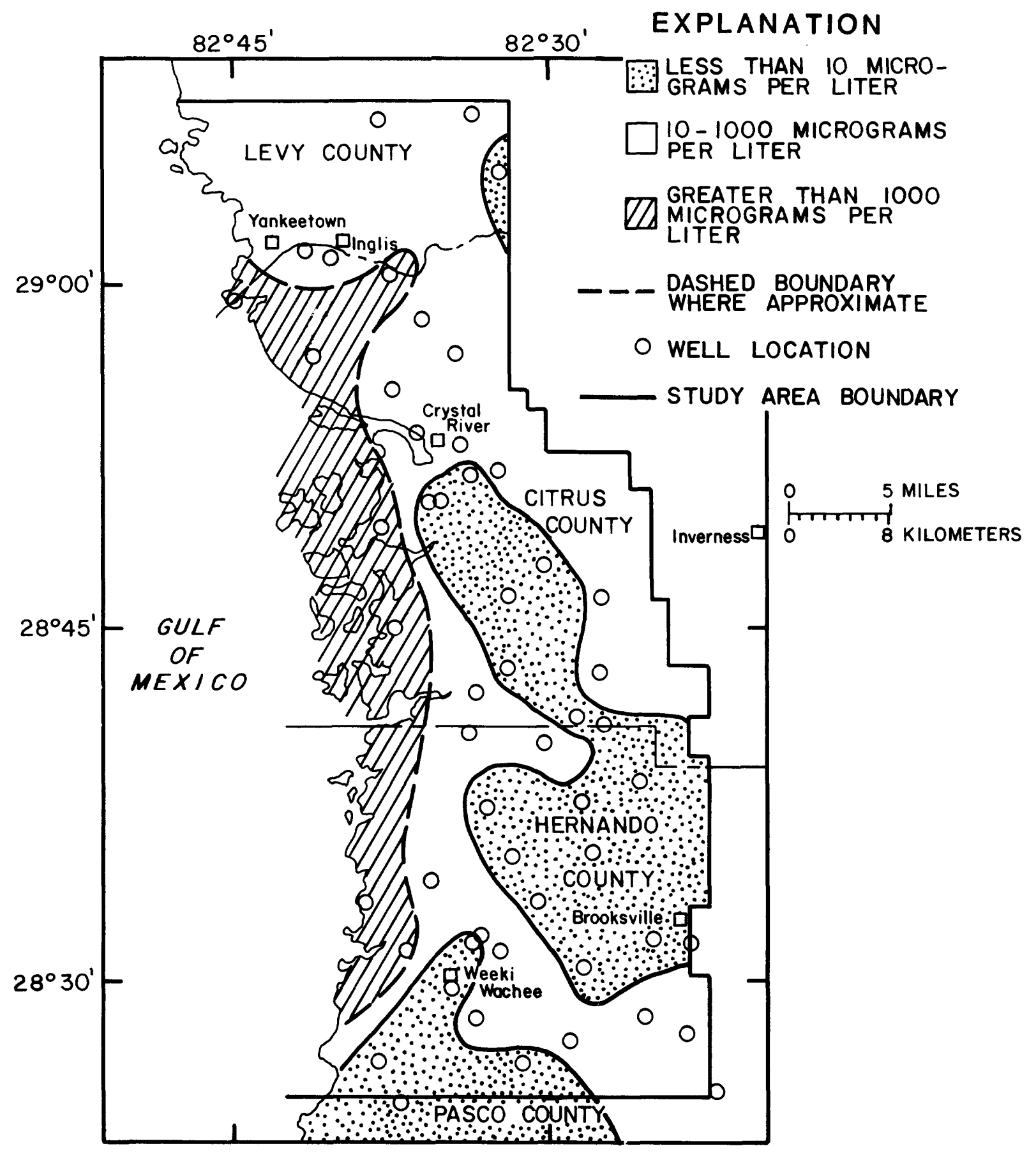

Figure 20.--Distribution of iron in ground water at a depth of 100 feet below land surface. 


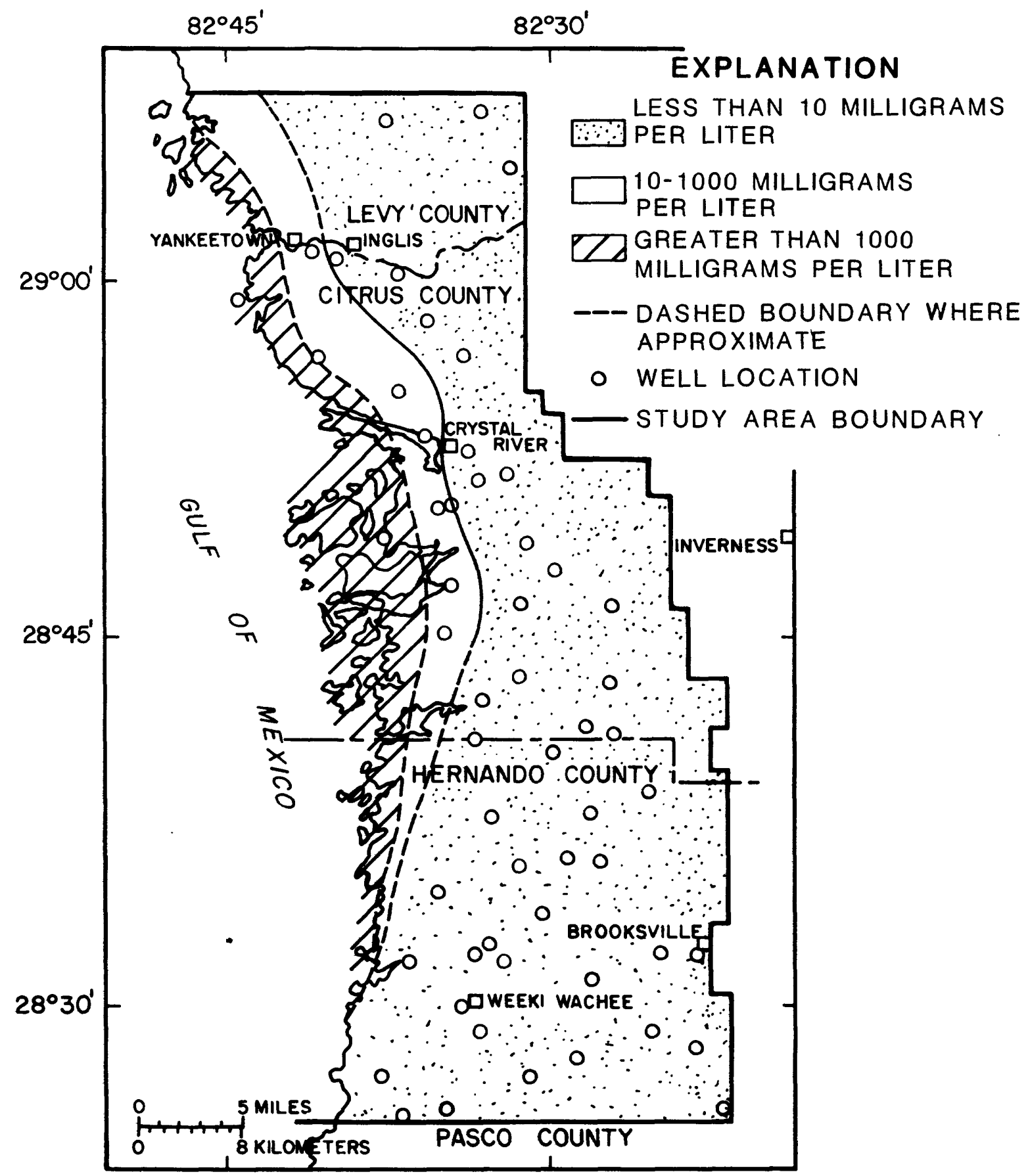

Figure 21.--Distribution of sulfate in ground water at a depth of 100 feet below land surface. 
Concentrations of all constituents, except silica, listed in tables 6 and 7 increase toward the coast and with depth. Higher concentrations also occur along the lower reaches of the Withlacoochee River. These high concentrations are probably associated with deeper aquifer water moving up in the section to discharge to the river and freshwater mixing with seawater along the coast. Silica concentrations are generally higher in inland areas and are probably associated with recharge through the sands and clays that overlie the Floridan aquifer.

Median values of constituents were almost always higher for water from springs and rivers than for water from wells. This is due to the tidal influence in the rivers and the proximity of the springs to the coast.

Three wells $(94,97$, and 98) located near the nuclear power plant at Crystal River were sampled for radionuclides. The well closest to the plant (98) had a gross alpha activity level of $11 \mathrm{pCi} / \mathrm{L}$ (picocuries per liter) and a gross beta activity of $15 \mathrm{pCi} / \mathrm{L}$. The gross alpha activity level of $11 \mathrm{pCi} / \mathrm{L}$ is below the recommended limit of $15 \mathrm{pCi} / \mathrm{L}$ set by the Florida Department of State (1977). The elevated alpha and beta activities are probably related to the mixture of seawater and freshwater in the well.

\section{Saltwater Encroachment}

A major threat to quality of ground water in the study area is saltwater encroachment along the coast. As demonstrated by Cooper and others (1964), saltwater underlies freshwater along a coast in a wedge that diminishes in thickness landward. A zone of mixing between saltwater and freshwater, caused by mechanical dispersion and chemical diffussion, is referred to in this report as the zone of transition. Boundaries of the zone of transition from saltwater $(19,000 \mathrm{mg} / \mathrm{L}$ chloride) to freshwater ( $25 \mathrm{mg} / \mathrm{L}$ chloride) can fluctuate with change in recharge and discharge to the aquifer.

The Ghyben-Herzberg theory (Davis and DeWiest, 1966) suggests that the position of the interface between saltwater and freshwater can be determined by knowing the head of freshwater above sea level. For every foot of head, the interface should be encountered 40 feet below sea level, or multinles thereof. For example, if the head were 3 feet, the interface would be at a depth of $120 \mathrm{feet}$. This would be true if the water were static and a sharp interface existed, which does not necessarily occur in nature. Theoretically, this relation between saltwater and freshwater would still apply in areas where the interface was very slightly sloped (Hubbert, 1940). In reality, freshwater flows toward the sea and seawater moves landward in a cyclic flow. This movement produces the zone of transition between saltwater and freshwater and reduces the inland extent that saltwater would reach under static conditions (Cooper and others, 1964).

Saltwater can be drawn into the freshwater aquifer by reduction in freshwater head (potentiometric surface) that could cause reduction or reversal in hydraulic gradient (slope of the potentiometric surface). The rate and extent of landward movement of saltwater is determined primarily by hydraulic gradient and hydraulic characteristics of the aquifer. 
Water from wells open within or near the zone of transition will increase in chloride concentrations if freshwater head is reduced. If the natural balance of the system is not disturbed and mixing due to pumping does not occur, chloride may return to near its original concentration after the return of normal head. However, if mixing has occurred owing to pumping of water from the zone of transition, high concentrations of chlorides may continue for a long period of time.

The general shape of the zone of transition along the coast is shown on figure 22. Cross sections A and B were constructed using well depths and chloride concentrations for water from wells located within 5-mile wide bands that extend about 13 and 20 miles inland from the coast (fig. 23). The most recent chloride values available were used to construct this section. Most data are for 1980, but data as early as 1965 have been used to define the shape of the interface. The slope of the zone of transition is steeper in Hernando County ( $\operatorname{section} B-B^{\prime}$ ) than in Citrus County. This is due to the steeper hydraulic gradient in Hernando County that is reflected in the potentiometric surface (figs. 11 and 12).

The position of the 250-mg/L chloride line at a depth of 100 feet below sea level, based on data from 1964 through 1975, was mapped by Mills and Ryder (1977) and by Causseaux and Fretwel1 (1982) who added data through 1980. Figure 23 shows the position of the line as defined by Causseaux and Fretwe11. A chloride concentration of $250 \mathrm{mg} / \mathrm{L}$ is the recommended limit for drinking water (Florida Department of State, 1977).

Changes in Chemica1 Quality

Because of problems of seawater intrusion, many wells in the coastal area have been sampled periodically for determination of chloride concentration and specific conductance. Figure 24 shows variations in chloride concentrations in several coastal wells from 1967 to 1980 as determined from samples taken bimonthly. We1ls 21,64 , and 75 show increased chloride concentration with time that suggests possible inland movement of saltwater.

The wide range in values from near 400 to more than $900 \mathrm{mg} / \mathrm{L}$ chloride at we11 21 may be associated with the time of sampling in relation to tides; however, the overall trend from 1970 to 1980 does appear to be in an upward direction. We1l 64 fluctuates between 100 and $300 \mathrm{mg} / \mathrm{L}$. The overall trend from 1969 to 1980 is in an upward direction. Well 75 also shows a definite upward trend between 1969 and 1980 from less than 2,000 to more than 3,000 mg/L chloride.

We1ls located a few miles inland, such as wells 85 and 97 , show fairly constant concentrations of chlorides in the freshwater range. Wel1 119 fluctuates, genera11\%, between 5 and $30 \mathrm{mg} / \mathrm{L}$ but shows no apparent trend with time. Shortterm fluctuations in concentrations are probably related to changes in rainfall. Plots of other wells (all within the zone of transition) show fairly constant average concentrations, although ranges vary considerably. 


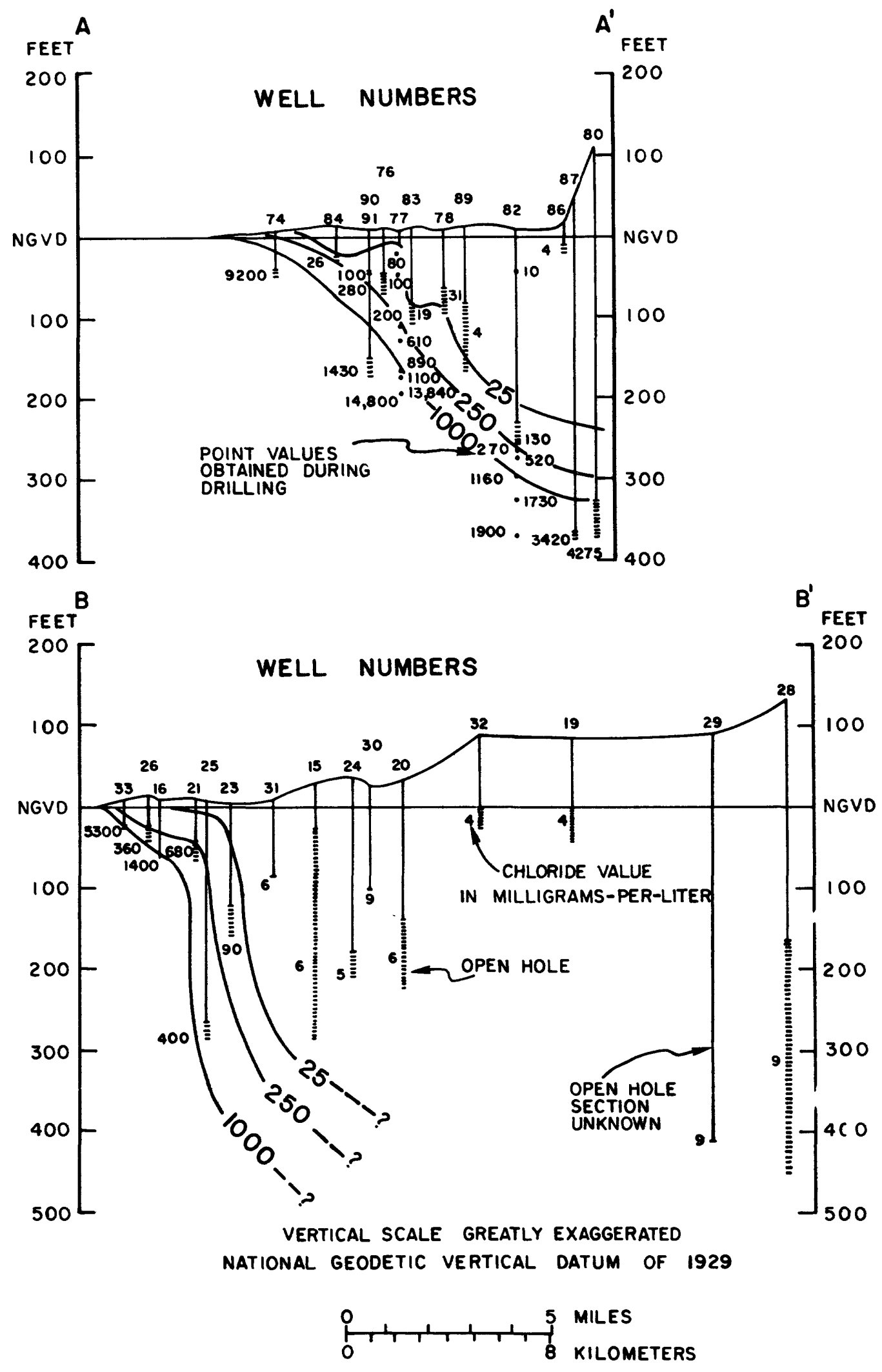

Figure 22.--Cross sections of the saltwater-freshwater zone of transition (modified from Causseaux and Fretwell, 1982). 


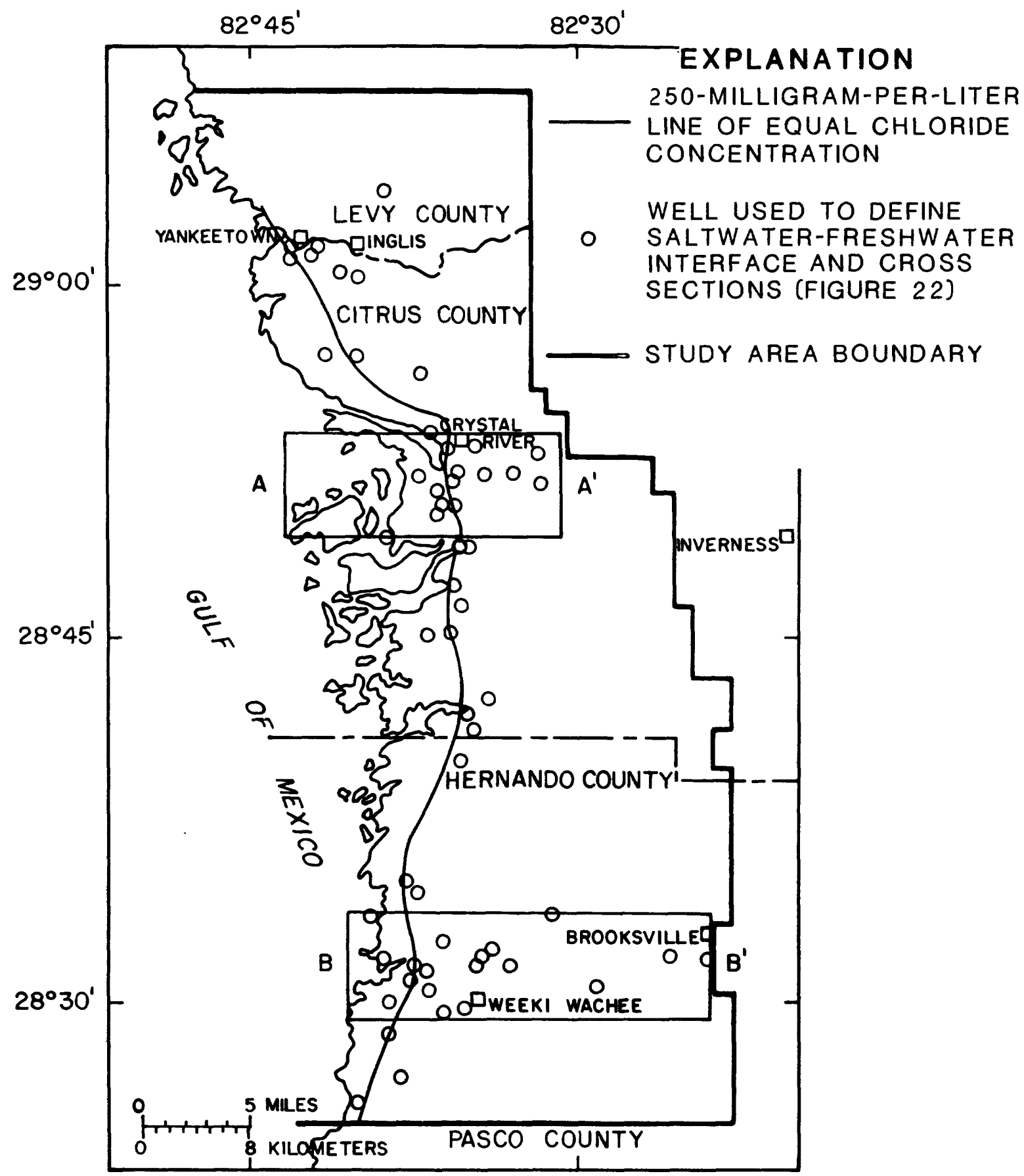

Figure 23.--Areal position of the 250-milligram-per-1iter line of equal chloride concentration at 100 feet below sea level (modified from Causseaux and Fretwe11, 1982). 


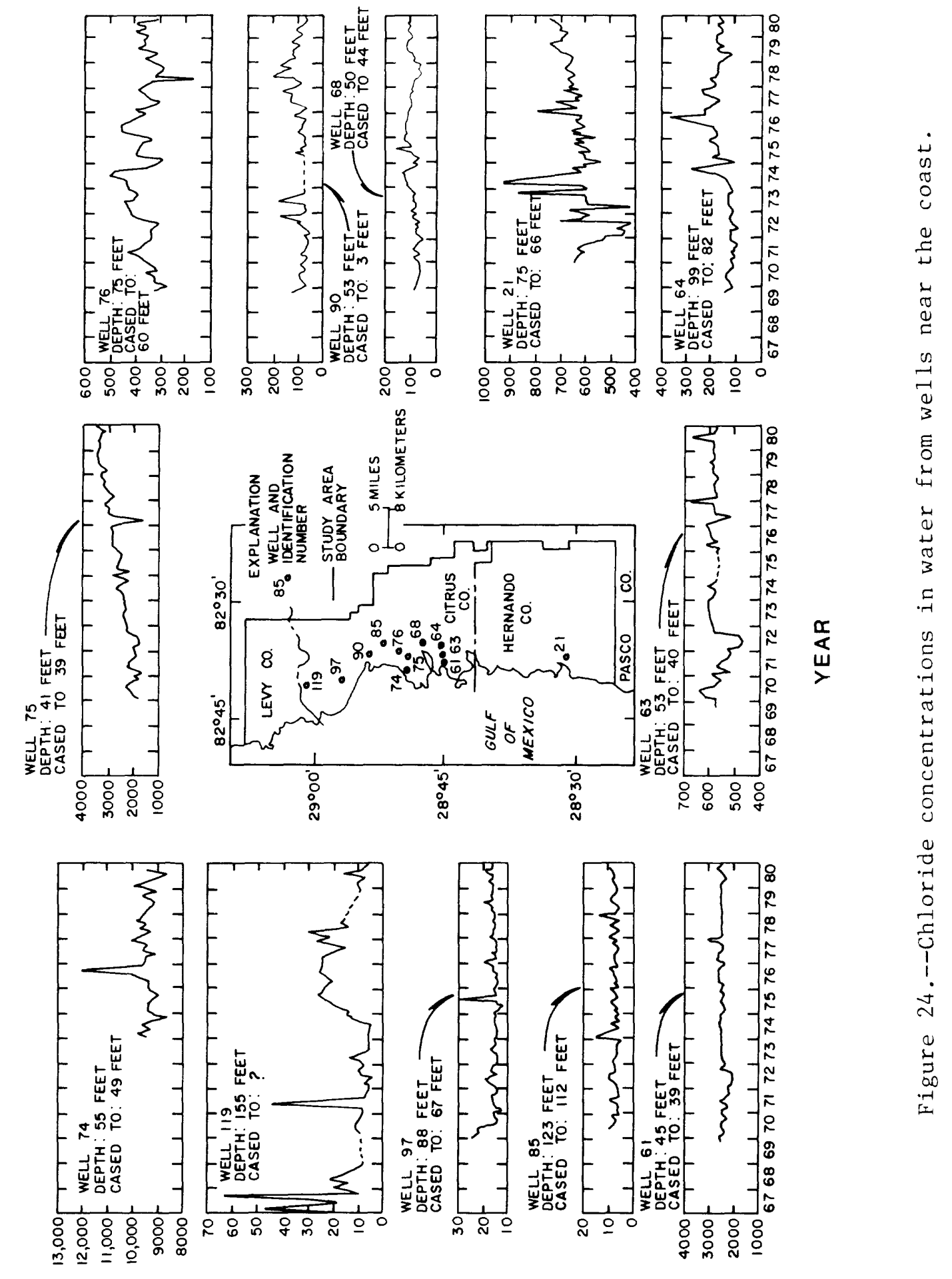

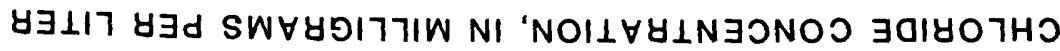


Wells 25, 82, 91, and 98, located near the coast (fig. 13) have wide ranges in chloride concentrations from sampling period to sampling period, which suggests a tidal effect on the wells. For example, chloride concentrations in well 25 fluctuated in an apparently random manner from $100 \mathrm{mg} / \mathrm{L}$ to $2,300 \mathrm{mg} / \mathrm{L}$ between 1976 and 1980. Chloride concentrations at well 82 fluctuated between $46 \mathrm{mg} / \mathrm{L}$ and $200 \mathrm{mg} / \mathrm{L}$ between July 1979 and November 1980. Fluctuations between $120 \mathrm{mg} / \mathrm{L}$ and $2,200 \mathrm{mg} / \mathrm{L}$ occurred in well 98 between 1965 and 1980. An even wider range of $520 \mathrm{mg} / \mathrm{L}$ to $5,000 \mathrm{mg} / \mathrm{L}$ has occurred in well 91 between 1970 and 1980 .

Chloride concentration in water is generally proportional to specific conductance of water. Hence, fluctuations in specific conductance related to gulf tides, as shown on figure 25, are also reflected by variations in chloride concentrations. Peaks in specific conductance and temperature at we 1125 correspond to peaks in tides at the Bayport tidal observation station approximately 2.3 miles west of the well. Fluctuations in specific conductance in water from the well ranged from about 1,400 to $9,600 \mu \mathrm{mho} / \mathrm{cm}$ (micromhos per centimeter) within a 30-minute period. This suggests that the well is finished within the transition zone between saltwater and freshwater. This may be true of many wells along the coast, especially wells that show large changes in chloride concentrations or specific conductance between times of sampling, but no general trend. Well 25 is an observation well where water levels are not affected by pumpage; therefore, the aquifer was not being stressed and mixing of saline water due to pumping was not occurring.

Surface resistivity methods can be used to define water-quality conditions by measuring changes in apparent resistivity with time and distance along a fixed traverse. Two electrical resistivity studies (Bisdorf and Zohdy, 1979; Fretwell and Stewart, 1981) were carried out in the area to test the feasibility of using this technique to locate saltwater at depth. Bisdorf and Zohdy (1979) mapped resistivities to depths of more than 1,000 feet. A geoelectric cross section on figure 26 shows variation in resistivity with depth for the upper 300 feet along a line near Homosassa Springs. Resistivities of 20 ohm-meters or less generally represent saltwater. The relation at depths greater than 300 feet is as yet inconclusive because well data are not available to verify the results.

Fretwel1 and Stewart (1981), using resistivity data, were able to nearly duplicate the location of the saltwater-freshwater interface defined from well data from north of Crystal River south to south of Homosassa (fig. 27). In addition to the position defined by Fretwell and Stewart (1981). lines defined by Causseaux and Fretwell (1982) and Mills and Ryder (1977) are shown. Discrepancies in the three lines are probably related in part to data being collected at varying tidal stages and dates and also to the fact that the resistivity study depicts water of a slightly higher chloride concentration than that depicted by well data defined by the other studies.

\section{GROUND-WATER RESOURCE DEVELOPMENT}

A quasi three-dimensional ground-water flow model for west-central Florida that includes the study area has been developed (Ryder, 1981). The quasi threedimensional model is a sequence of two-dimensional ground-water flow models connected by vertical leakage through the confining beds. The model can be used to 

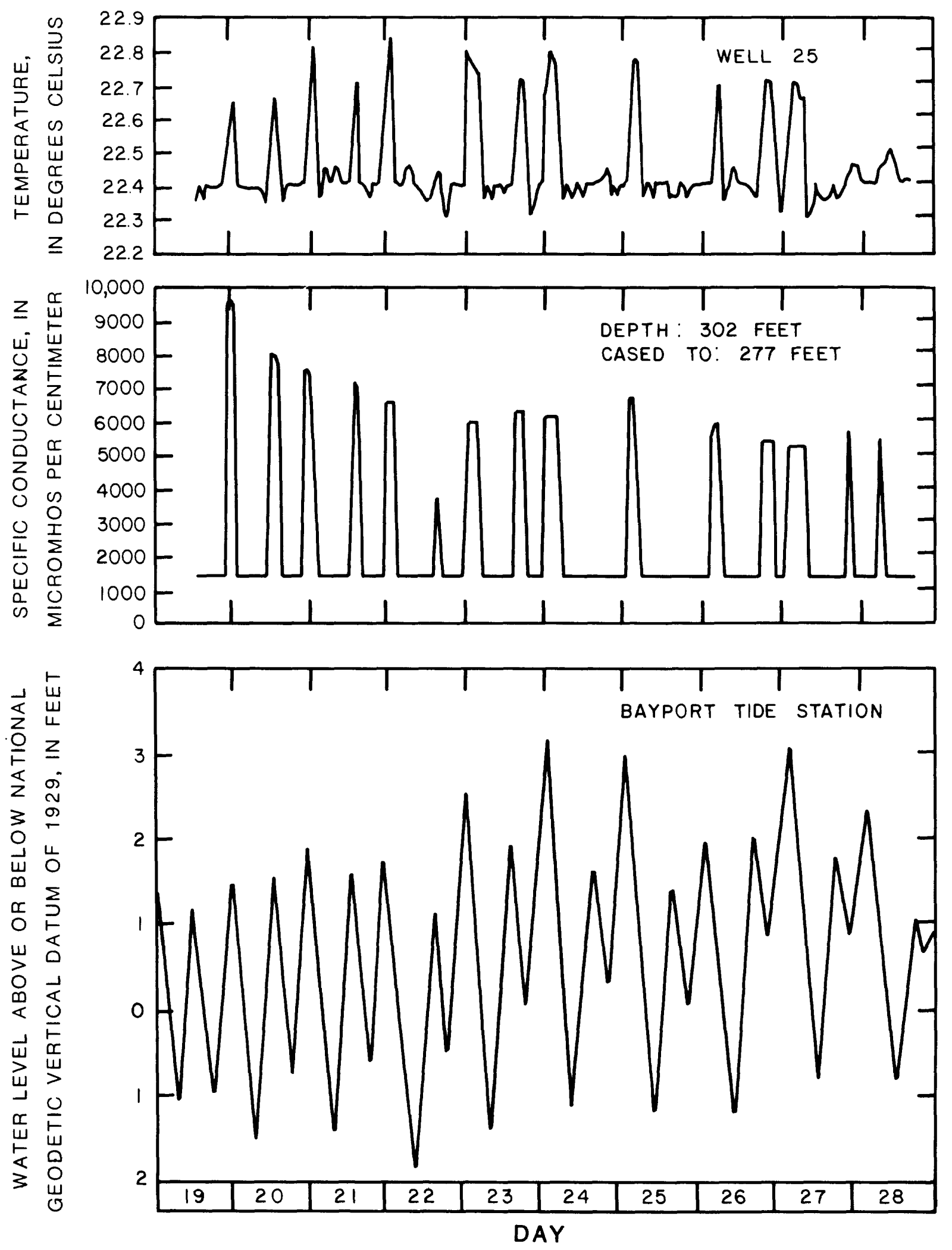

Figure 25.--Comparison of tidal fluctuations at Bayport with temperature and specific conductance of water from well 25, November 19 to 28, 1980 . 


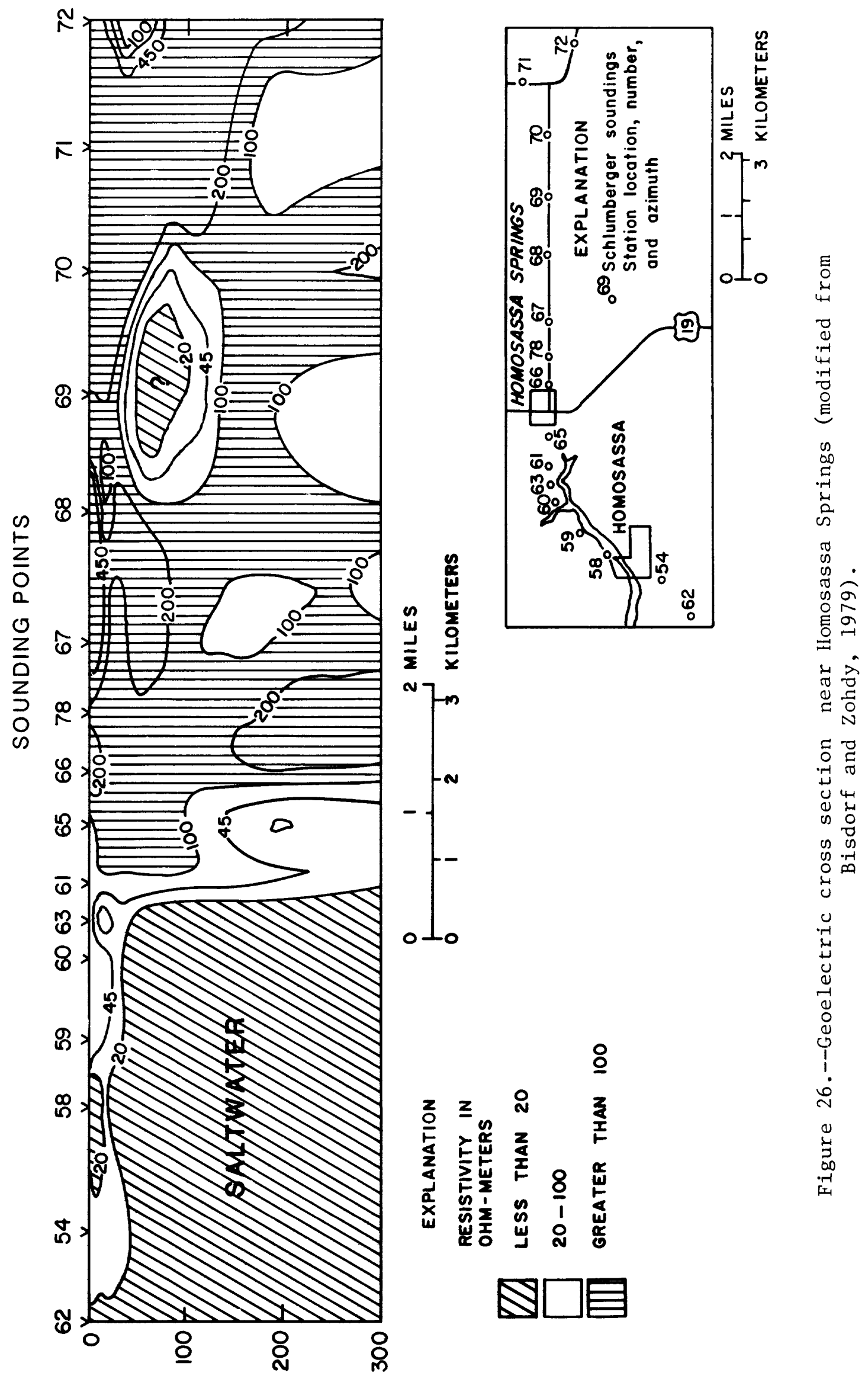

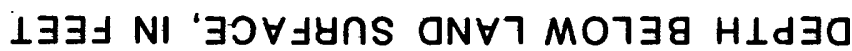




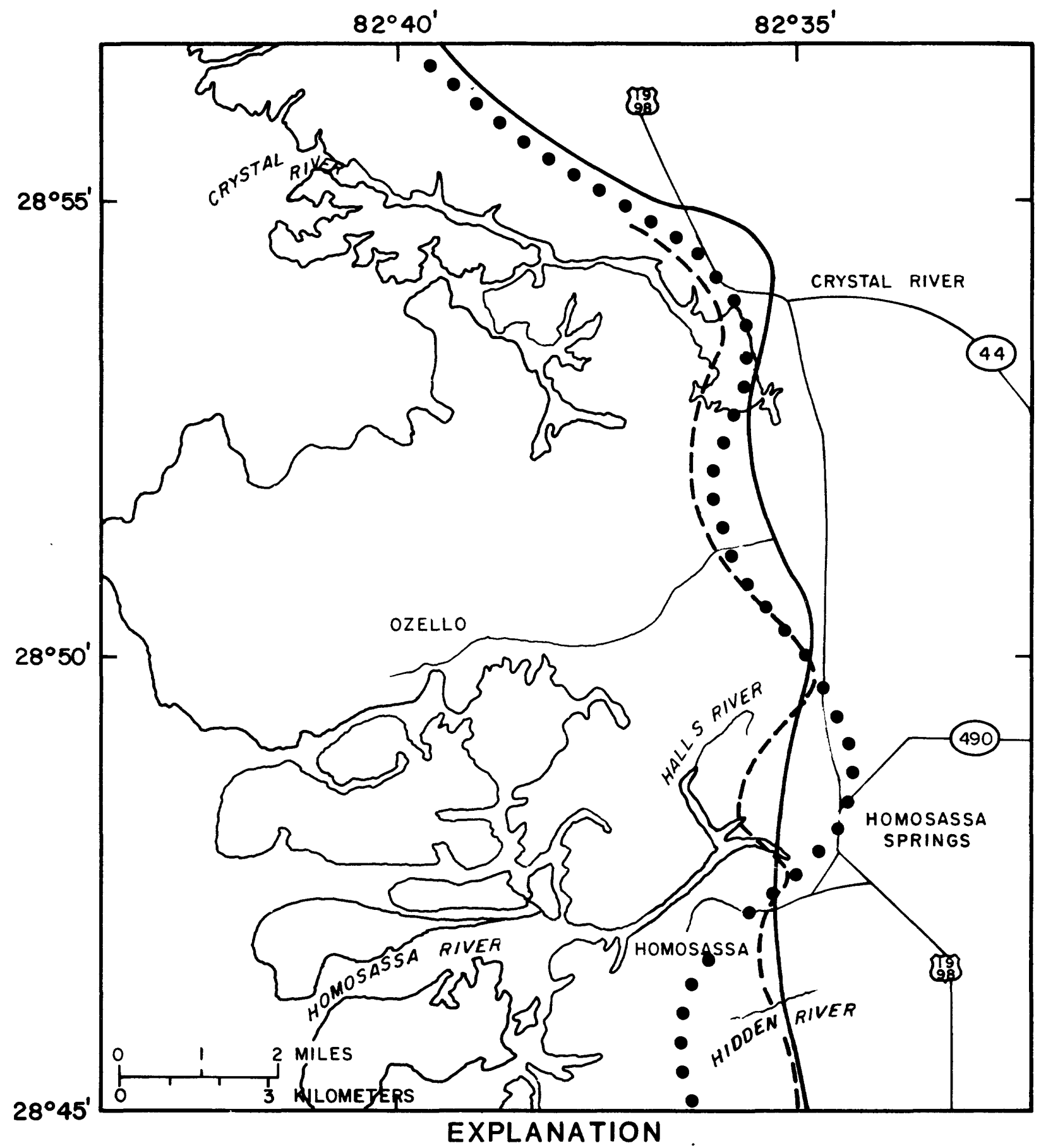

1000-MILLIGRAM-PER-LITER CHLORIDE INTERFACE AT DEPTH OF 100 FEET BELOW LAND SURFACE BASED ON RESISTIVITY 1978

(FRETWELL AND STEWART, 1981 )

250-MILLIGRAM-PER-LITER CHLORIDE INTERFACE AT DEPTH OF IOO FEET BELOW LAND SURFACE BASED ON WELL DATA 1964 THROUGH 1980 (CAUSSEAUX AND FRETWELL, 1982)

250-MILLIGRAM-PER-LITER CHLORIDE INTERFACE AT DEPTH OF 100 FEET BELOW LAND SURFACE BASED ON WELL DATA 1964 THROUGH 1975 (MILLS AND RYDER, (977)

Figure 27.--Saltwater-freshwater interface in the Floridan aquifer based on electrical resistivity compared to that based on well data. 
predict drawdowns resulting from pumpage, with reservation and qualification. Because no appreciable ground-water development has occurred in the study area, the distributions of aquifer properties derived from simulating predevelopment flow conditions have not been verified. Therefore, the results of predictive pumping simulations must be regarded as speculative at best. However, modelderived aquifer properties result from extensive calibration simulations and are within realistic limits based on available field data. With this deficiency, the model is still the best available tool at present for predicting drawodwns. For purposes of simulation, the aquifer is assumed to be homogeneous and isotropic. The aquifer is treated as a single layer. Another limitation of the model is that the coastal freshwater-saltwater interface was simulated as a no-flow boundary. This does not allow for potential inland movement of saltwater due to pumping. The model was used to estimate the impact of pumping from the Floridan aquifer at several points in the study area.

Input to the model includes: (1) estimated annual direct recharge to the limestone aquifer (net after subtracting evapotranspiration and surface runoff) when the aquifer is unconfined; (2) vertical leakage to the limestone aquifer from the surficial aquifer in confined areas; (3) estimated transmissivity; (4) spring-pool elevations at the larger springs; and (5) a hydraulic conductance that describes the linear relation between head difference and flnw rate at each spring. The model has a grid spacing of 4 miles, which means that input values are averages over a $16-\mathrm{mi}^{2}$ area. No upward leakage is assumed from the base of the aquifer.

Five steady-state simulations were made, each with pumpage of $40 \mathrm{Mgal} / \mathrm{d}$, from various hypothetical wells (figs. 28 through 30). A pumping rate of 40 $\mathrm{Mgal} / \mathrm{d}$ was selected because this is generally the maximum permitted average daily pumpage from a well field at the present time (1982) in the Southwest Florida Water Management District. A single pumping well was used in the model at each selected site, although several wells would be used in an actual well field.

These particular sites were selected for various reasons. Sites $20: 42$ and 20:38 (fig. 28) show extreme variations in drawdowns that can result from placement of wells at different locations due primarily to differences in aquifer characteristics and in part to amount of recharge. Sites $17: 31$ (fig. 30), 18:31 (fig. 29), and 18:34 (fig. 28) were selected because they are near existing ground-water development sites.

As of 1980, the total ground-water withdrawal for the entire study area was $44 \mathrm{Mgal} / \mathrm{d}$ so that a pumping rate of $40 \mathrm{Mgal} / \mathrm{d}$ at any one site is an exaggeration of present demand and represents a worst case situation. The particular combinations of well location and pumping rate were selected to emphasize variations in response of the aquifer from site to site, rather than drawdown at a particular site.

Based on data shown in figures 28 through 30 , a maximum radius of influence at a drawdown of 1 foot at the selected test sites from pumping $40 \mathrm{Mgal} / \mathrm{d}$ to steady-state is 18 miles inland and about 10 miles seaward from node 18:31 in Hernando County (fig. 29). The pumping center is located 10 miles inland from the saltwater-freshwater interface and 12 miles inland from the coast. This 

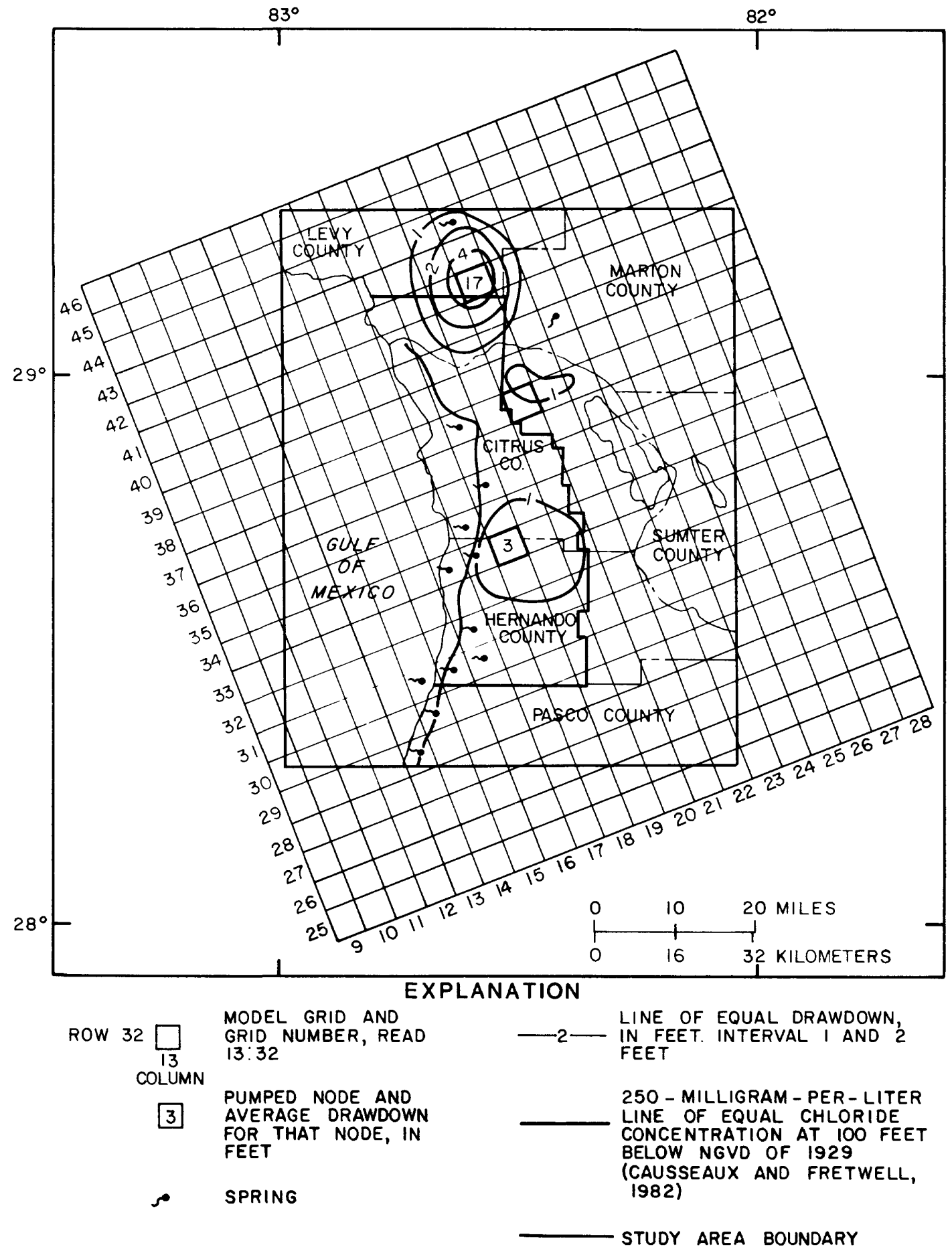

Figure 28.--Drawdown caused by pumping three hypothetical wells at different times to steady-state at a rate of 40 million gallons per day each. 

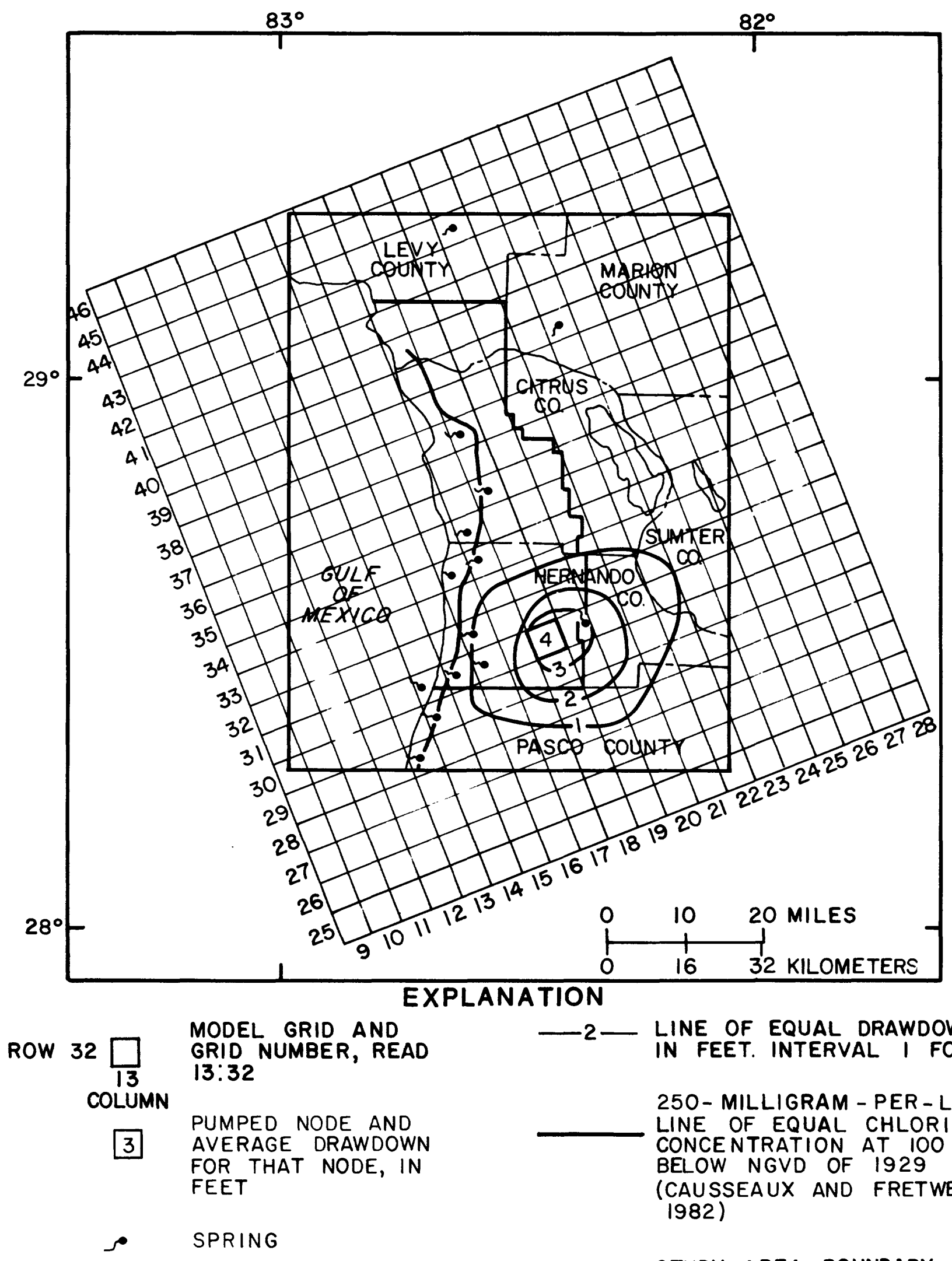

LINE OF EQUAL DRAWDOWN,
IN FEET. INTERVAL I FOOT

250- MILLIGRAM - PER - LITER

LINE OF EQUAL CHLORIDE

CONCENTRATION AT 100 FEET

BELOW NGVD OF 1929

(CAUSSEAUX AND FRETWELL, 1982)

STUDY AREA BOUNDARY

Figure 29.--Drawdown caused by pumping a hypothetical well in central Hernando County to steady-state at a rate of 40 million gallons per daỳ. 


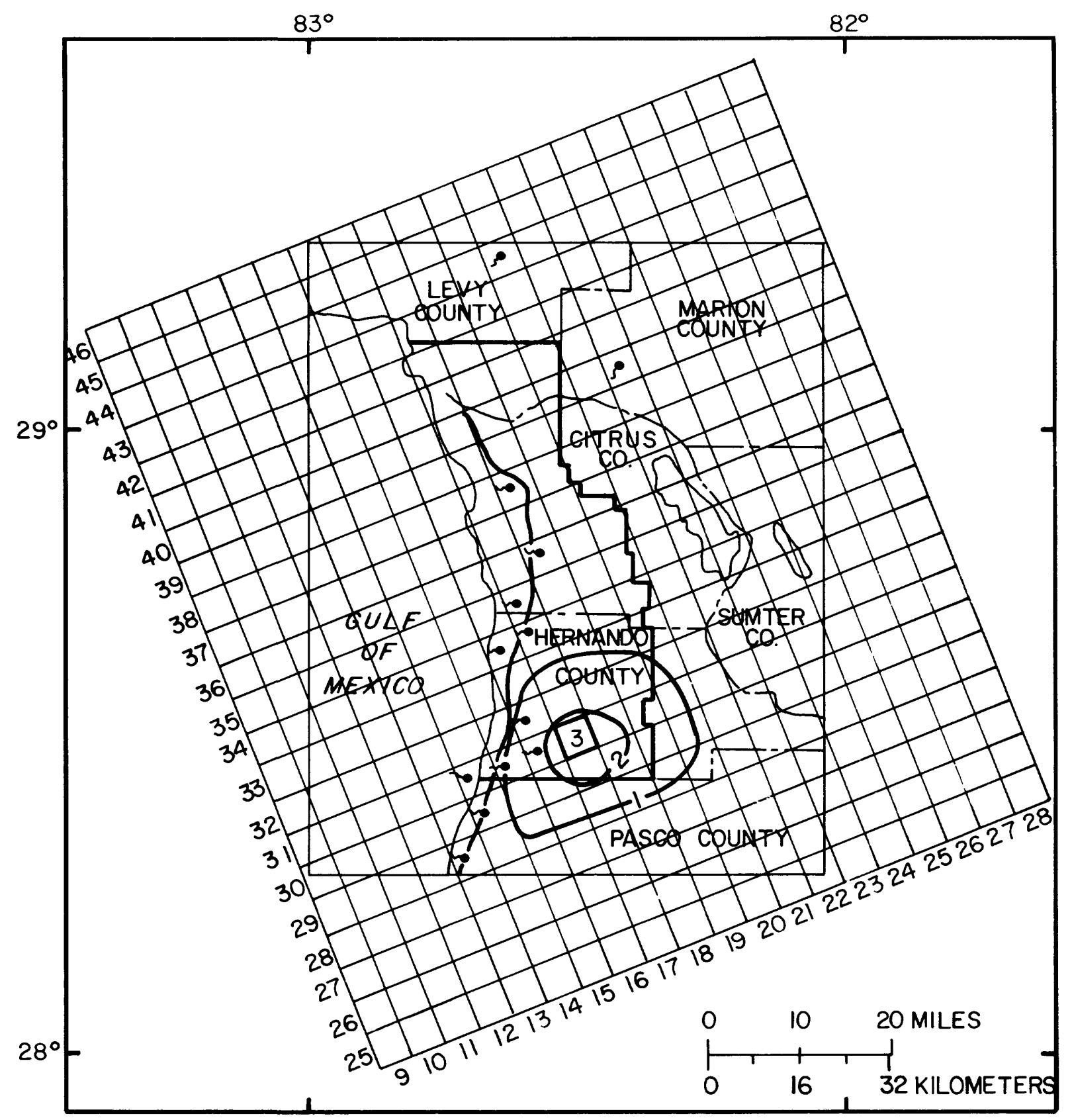

\section{EXPLANATION}

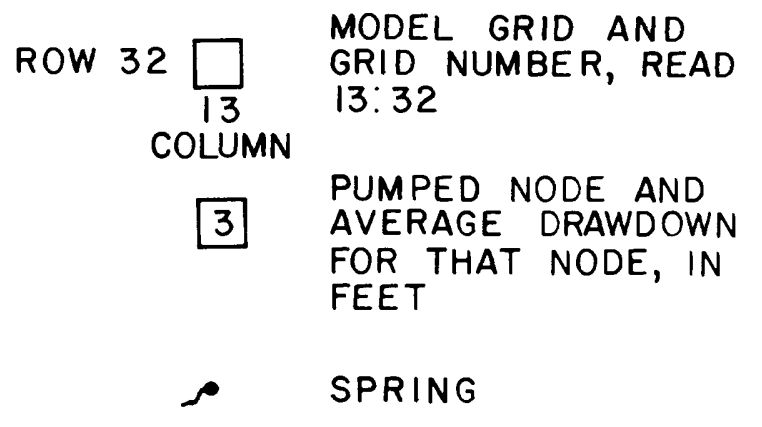

$-2-$ LINE OF EQUAL DRAWDOWN,
IN FEET. INTERVAL I FOOT

250-MILLIGRAM-PER-LITER LINE OF EQUAL CHLORIDE CONCENTRATION AT 100 FEET BELOW NGVD OF 1929

(CAUSSEAUX AND FRETWELL, 1982)

Figure 30.--Drawdown caused by pumping a hypothetical well in southcentral Hernando County to steady-state at a rate of 40 million gallons per day. 
suggests a minimum safe distance of 12 miles inland for locating a $40 \mathrm{Mga} 1 / \mathrm{d}$ well field to maintain a drawdown of 1 foot or less at the interface. A smaller rate of pumpage would result in less drawdown. Theoretically, any amount of drawdown will allow the interface to move inland. However, a drawdown of 1 foot at the interface could potentially cause upconing of approximately 40 feet. The minimum radius of influence of a drawdown of 1 foot at the selected test sites is about 8 miles at node 20:38 (fig. 28) in northern Citrus County. Each site is unique and potential well-field sites need to be studied in detail to determine effects of pumping. Major variables affecting the radius of influence are transmissivity, storativity, and overlapping cones of influence (nearby wells).

Maximum drawdown at any of the sites was at node 20:42 (fig. 28) of 17 feet (which is an average for the $16-\mathrm{mi}^{2}$ node) that theoretically could result in upconing of 680 feet of saltwater if saltwater is present near the base of the aquifer. A deep monitor well would be advisable in any well field in the coastal area to monitor for any upward movement of saltwater. The minimum average drawdown for any of the selected nodes is 1 foot at node 20:38 (fig. 28) inland from the coast about 12 miles.

Ground-water development in the study area will lower the potentiometric surface which could induce upconing or lateral intrusion of saltwater, reduce flow of water from coastal springs, and increase the likelihood of sinkhole development (Sinclair, 1982). Lateral intrusion of saltwater can be minimized by placing well fields inland from the coast so that their drawdowns have little or no measurable effect on the saltwater-freshwater interface. Reduced flow to springs can also be avoided by placing well fields so that drawdown is minimized at the springs (Sinclair, 1978).

\section{SUMMARY AND CONCLUSIONS}

Dominant features of the karstic terrain of coastal Citrus, Hernando, and Levy Counties are the Brooksville Ridge, a series of eroded ridges at the eastern edge of the study area, and two well-defined Pleistocene beaches and their associated terraces west of the Brooksville Ridge. Many square miles of saltwater marshes occur near the gulf.

Most nonmarsh land is forest interspersed with cropland and pasture. Rock mining is the major industry and accounts for most of the present (1982) water use. The number of small housing developments is increasing rapidly along the coast in the study area. Population is expected to continue growing rapidly for the next few years, resulting in increased demands on the area's ground-water resources.

The Floridan aquifer, composed of many hundreds of feet of carbonate rock of Tertiary age, occurs at or near land surface throughout the study area. Some of the oldest exposed aquifer rock in Florida crops out in the northern part of the area. There is no evidence of a continuous water-table aquifer in surficial deposits. The Floridan aquifer is generally unconfined or semiconfined by sands and clays throughout most of the area. 
Most of the water discharged from the study area each day occurs through coastal springs. This water is derived from rainfall within or outside the area. Water entering the area from outside is almost entirely ground-water flow. Water enters the Floridan aquifer in recharge areas to the southeast, east, and northeast and flows generally coastward toward coastal springs. Surface runoff is virtually nonexistent except seaward of the springs and in the Withlacoochee River that traverses the northern part of the study area.

Transmissivities of the Florigan aquifer are estimated to range from $2.0 \times 10^{4}$ general increases toward the springs.

The potentiometric surface of the Floridan aquifer changes in response to variations in rainfall, pumpage, and tidal fluctuations near the coast. Contours of the potentiometric surface shift slightly seaward between the dry and wet seasons (May and September). Hydrographs for seven wells showed seasonal fluctuations in water levels to be greater than annual ones from the period 1966 through 1980 for most wells. The greatest declines in water-level over the 14-year period have occurred in the southeastern part of the study area.

Ninety-nine percent of the $44 \mathrm{Mgal} / \mathrm{d}$ of water used for irrigation, industrial, public, and rural supply in the study area is ground water. About $32 \mathrm{Mgal} / \mathrm{d}$ of water is withdrawn from the Floridan aquifer for industrial use. Ninety-nine percent of this is used for rock mining. Rural water use accounts for $6.3 \mathrm{Mgal} / \mathrm{d}$. Water withdrawn for irrigation is estimated at $3.9 \mathrm{Mgal} / \mathrm{d}$. In 1980, water used for public supply was $1.6 \mathrm{Mgal} / \mathrm{d}$.

Water in the Floridan aquifer is generally of good quality except near the coast where saltwater is present. Concentrations of all constituents, except silica, increase toward the coast and with depth. Median values of constituents were generally higher for water from springs and rivers than for water from wells due to the tidal influence in the rivers.

Although values vary considerably, most wells sampled for chloride showed no apparent trend with time. However, a few wells located near the coast showed an upward trend in chloride concentrations with time suggesting saltwater encroachment; the only major threat to freshwater supplies. Surface resistivity measurements have been used to locate the saltwater-freshwater interface in Citrus County.

A quasi three-dimensional model was used to predict drawdowns resulting from a hypothetical pumping rate of $40 \mathrm{Mgal} / \mathrm{d}$ at various sites throughout the study area. The radius of influence ranged from about 8 miles in northern Citrus County to about 18 miles in central Hernando County. Average drawdowns for each pumping node ranged from 1 foot in northern Citrus County to 17 feet in southern Levy County. These variations are due to different aquifer characteristics and in part to differences in amount of recharge at each site. A reduction in head near the saltwater-freshwater interface could cause upconing or lateral intrusion of saltwater, reduction in flow of water to the coastal springs, or sinkhole development. Lateral intrusion of saltwater could be minimized by placing well fields inland from the coast so that their drawdowns do not intersect the saltwater-freshwater interface. Placing well fields inland from the springs would also minimize drawdown at the springs. 
American Society for Testing and Materials, 1972, Metric Practice Guide: E 380-72E, p. 22 .

Anderson, Warren, and Laughlin, C. P., 1982, Geohydrology of the Floridan aquifer in the Withlacoochee River basin of the Southwest Florida Water Management District: U.S. Geological Survey Water-Resources Investigations OpenFile Report, 82-331.

Bisdorf, R. J., and Zohdy, A. A. R., 1979, Geoelectric investigations with Schlumberger soundings near Venice, Parrish, and Homosassa, Florida: U.S. Geological Survey Open-File Report 79-841, 115 p.

Buono, Anthony, and Rutledge, A. T., 1979, Configuration of the top of the Floridan aquifer, Southwest Florida Water Management District and adjacent. areas: U.S. Geological Survey Water-Resources Investigations Open-File Report 78-34.

Buono, Anthony, Spechler, R. M., Barr, G. L., and Wolansky, R. M., 1979, Genera1ized thickness of the confining bed overlying the Floridan aquifer, Southwest Florida Water Management District: U.S. Geological Survey Water-Resources Investigations Open-File Report 79-1171.

Carr, P. A., and Van Der Kamp, G. S., 1969, Determining aquifer characteristics by the tidal method: Water Resources Research, v. 5, no. 5, p. 1023-1031.

Causseaux, K. W., and Fretwe11, J. D., 1982, Position of the saltwater-freshwater transition zone in the upper part of the Floridan aquifer, southwest Florida, 1979: U.S. Geological Survey Open-File Report, 82-90.

Cherry, R. N., Stewart, J. W., and Mann, J. A., 1970, General hydrology of the Middle Gulf area, Florida: Florida Bureau of Geology Report of Investigations 56, $96 \mathrm{p}$.

Cocke, C. W., 1945, Geology of Florida: Florida Geological Survey Bulletin 29, $339 \mathrm{p}$.

Cooper, H. H., Jr., Kohout, F. A., Henry, H. R., and Glover, R. E., 1964, Sea water in coastal aquifers: U.S. Geological Survey Water-Supply Paper $1613-\mathrm{C}, 84 \mathrm{p}$.

Cox, C. R., and Ast, D. B., 1951, Water fluoridation - a sound public health practice: American Water Works Association Journal, v. 43, no. 8, p. 641-648.

Davis, J. C., 1973, Statistics and data analysis in geology: New York, John Wiley, p. 473-533.

Davis, S. N., and DeWiest, J. M., 1966, Hydrngeology: New York, John Wiley, p. 238 .

Dean, H. T., Arnold, F. A., and Elvoloe, E1ias, 1942, Domestir water and dental caries: Public Health Reports, v. 57, no. 32., p. 1155-1179.

Dohrenwend, R. E., 1977, Evapotranspiration patterns in Florida: Florida Scientist, v. 40, no. 2, p. 184-192.

Duerr, A. D., and Trommer, J. T., 1981, Estimated water use in the Southwest Florida Water Management District and adjacent areas, 1980: U.S. Geological Survey Open-File Report 81-1060, 60 p.

Durfor, C. N., and Becker, Edith, 1964, Public water supplies of the 100 largest cities in the United States, 1962: U.S. Geological Survey Water-Supply Paper $1812,364 \mathrm{p}$. 
Faulkner, G. L., 1972, Mid-1971 ground-water conditions at Yankeetown wel1 field, Levy County, Florida: U.S. Geological Survey open-file report FL-72001, 18 p.

1973a, Ground-water conditions in the lower Withlacoochee River-Cross Florida Barge Canal complex area: U.S. Geological Survey Water-Resources Investigations $4-72,31 \mathrm{p}$.

1973b, Geohydrology of the Cross-Florida Barge Canal area with special reference to the Ocala vicinity: U.S. Geological Survey Water-Resources Investigations $1-73$, p. 117.

Fenneman, N. M., 1938, Physiography of Eastern United States: New York, McGrawHi11, $714 \mathrm{p}$.

Ferguson, C. E., Lingham, C. W., Love, S. K., and Vernon, R. O., 1947, Springs of Florida: Florida Geological Survey Bulletin 31, 461 p.

Ferris, J. G., Knowles, D. B., Brown, R. H., and Stallman, R. W., 1961, Theory of aquifer tests: U.S. Geological Survey Water-Supply Paper 1536-E, 174 p.

Florida Department of State, 1977, Rules of the Department of Environmental Regulation, water supplies, Chapter 17-22, in Florida Administrative Code: Tallahassee.

Florida Department of Water Resources, 1966, Florida land and water resources, southwest Florida.

Fretwel1, J. D., and Stewart, M. T., 1981, Resistivity study of a coastal karst terrain, Florida: Ground Water, v. 19, no. 2, p. 156-162.

Geraghty and Miller, Inc., 1979, Hydrologic report on Florida Power Corporation's proposed well field to supply water to units 4 and 5 at Crystal River, Florida: Consultant's report prepared for Florida Power Corporation, in files of the Southwest Florida Water Management District, $57 \mathrm{p}$.

German, E. K., 1977, The hydrology of Lake Rousseau, west-central Florida: U.S. Geological Survey Water-Resources Investigations 77-126.

Goldberg, E. D., 1963, Chemistry - the oceans as a chemical system, in Hill, M. N., Composition of sea water, comparative and descriptive oceanography, volume 2 of The Sea: New York, Interscience Publishers, p. 3-25.

Hem, J. D., 1970, Study and interpretation of the chemical characteristics of natural water: U.S. Geological Survey Water-Supply Paper 1473, 363 p.

Holdridge, L. R., 1967, Life zone ecology: Tropical Srience Center, San Jose, Costa Rica.

Hubbert, M. K., 1940, The theory of groundwater motion: Journal of Geology, v. 48, p. 785-944.

Hydrogage, Inc., 1980a, Water level and well inventory data for Citrus and Hernando Counties, Florida: Hydrogage, Inc., Data Report, 14 p.

1980b, Water level and well inventory data for Marion and Levy Counties, Florida: Hydrogage, Inc., Data Report, $5 \mathrm{p}$.

Kulp, J. L., Turekian, K. K., and Boyd, D. W., 1952, Strontium content of limestone and fossils: Geological Society of America Bulletin, v. 64, p. 879896.

Leggette, Brashears and Graham, Inc., 1978, Development and testing program phase I, Cross Bar Ranch well field, Pasco County, Florida, June 1978: West Coast Regional Water Supply Authority, monthly status report. 
Lohman, S. W., 1979, Ground-water hydraulics: U.S. Geological Survey Professional Paper 708, $70 \mathrm{p}$.

Lohr, E. W., and Love, S. K., 1954, The industrial utility of public water supplies of the United States; Part 1, States east of the Mississippi River: U.S. Geological Survey Water-Supply Paper 1299, 639 p.

Mann, J. A., and Cherry, R. N., 1969, Large springs of Florida's sun coast, Citrus and Hernando Counties: Florida Geological Surve $y$ Leaflet 9, 24 p.

Matson, G. C., and Sanford, Samue1, 1913, Geology and ground waters of Florida: U.S. Geological Survey Water-Supply Paper 319, $445 \mathrm{p}$.

Mckee, J. F., and Wolf, N. W., 1963, Water quality rriteria: California State Water Quality Control Board Publication 3-A, 548 p.

Mills, L. R., and Ryder, P. D., 1977, Saltwater intrusion in the Floridan aquifer, coastal Citrus and Hernando Counties, Florida, 1975: U.S. Geological Survey Water-Resources Investigations 77-100.

National Academy of Sciences and National Academy of Engineering, 1973, Water quality criteria, 1972: U.S. Environmental Protection Agency Report EPA R3 73 033, 594 p.

National Oceanic and Atmospheric Administration, 1980, C1imatological Data, Annual Summary, Florida: v. 84, $12 \mathrm{r}$.

Parker, G. G., Ferguson, G. E., Love, S. K., and others, 1955, Water resources of southeastern Florida, with special reference to the geology and ground water of the Miami area: U.S. Geological Survey Water-Supply Paper 1255, $965 \mathrm{p}$.

Puri, H. S., and Vernon, R. O., 1964, Summary of the geology of Florida and a guidebook to the classic exposures: Florida Geological Survey Special Publication 5, 312 p.

Rosenau, J. C., Faulkner, G. L., Hendry, C. W., Jr., and Hu11, R. W., 1977, Springs of Florida (revised): Florida Bureau of Geology Bulletin 31, $461 \mathrm{p}$.

Ryan, W. J., 1937, Water treatment and purification: New York, McGraw-Hill, $242 \mathrm{p}$.

Ryder, P. D., 1981, Digital model of predevelopment flow in the Tertiary limestone (Floridan) aquifer system in west-central Florida: U.S. Geological Survey Water-Resources Investigations 81-54, $66 \mathrm{p}$.

Seaburn and Robertson, Inc., 1980a, Hydrologic evaluations for a new water supply facility, City of Crystal River, Florida: Consultant's report for city of Crystal River, Florida, and Glace and Radcliffe, Inc., in files of the U.S. Geological Survey, $44 \mathrm{p}$.

1980b, Results of hydrogeologic testing at Sugarmill Woods, Florida: Consultant's report for Punta Gorda Developers, Inc., in files of the U.S. Geological Survey, $40 \mathrm{p}$.

Sellards, E. H., 1908, A preliminary report on the underground water supply of central Florida: Florida Geological Survey Bulletin 1, 103 p.

Sinclair, W. C., 1978, Preliminary evaluation of the water-supply potential of the spring-river system in the Weeki Wachee area and the lower Withlacoochee River, west-central Florida: U.S. Geological Survey Water-Resources Investigations $78-74,40 \mathrm{p}$. 
Sinclair, W. C., 1982, Sinkhole development resulting from ground-water withdrawals in the Tampa area, Florida: U.S. Geological Survey Water-Resources Investigations $81-50,24 \mathrm{p}$.

Southwest Florida Water Management District, 1976, Land use map atlas: Water Resources Management Study, Four Rivers Basin Area.

Stringfield, V. T., 1936, Artesian water in the Florida Peninsula: U.S. Geological Survey Water-Supply Paper 773-C, p. 115-195.

Theis, C. V., 1940, The source of water derived from wells, essential faclors controlling the response of an aquifer to development: American Society of Civil Engineers, Civil Engineering Magazine, May 1940, p. 227-280.

Thom, B. G., 1967, Coastal and fluvial land forms: Harry and Marion Counties, South Carolina: Baton Rouge, Louisiana University Press, $75 \mathrm{p}$.

U.S. Environmental Protection Agency, 1977, National interim primary drinking water regulations: EPA-570/9-76-003, p. 159.

1979, National secondary drinking water regulations: Federal Register, v. 44 , no. 140,8 p.

U.S. Geological Survey, 1977, Water resources data for Florida-1976, southwest Florida: U.S. Geological Survey Water-Data Report FL-76-3.

1980, Water resources data for Florida-1979, southwest Florida: U.S. Geological Survey Water-Data Report FL-79-3.

1981, Water resources data for Florida-1980, southwest Florida: U.S. Geological Survey Water-Data Report FL-80-3A.

University of Florida, 1979, Florida statistical abstracts: Gainesville, Bureau of Economic and Business Research, College of Business Administration, University Presses of Florida.

1980a, Florida statistical abstracts: Gainesville, Bureau of Economic and Business Research, College of Business Administration, University Presses of Florida.

1980b, Population projections: Gainesville, Bureau of Economic and Business Research, College of Business Administration, University Presses of Florida.

Vernon, R. O., 1951, Geology of Citrus and Levy Counties, Florida: Florida Geological Survey Bulletin 33, 256 p., 2 pl.

Vernon, R. O., and Puri, H. S., 1964, Geologic map of Florida: Florida Geological Survey Map Series 18.

Visher, F. N., and Hughes, G. H., 1969, The difference between rainfall and potential evaporation in Florida: Florida Bureau of Geology Map Series 32.

Wetterha11, W. S., 1964, Geohydrologic reconnaissance of Pasco and southern Hernando Counties, Florida: Florida Geological Survey Report of Investigations $34,28 \mathrm{p}$.

1965, Reconnaissance of springs and sinks in west-central Florida: Florida Geological Survey Report of Investigations 39, $42 \mathrm{p}$.

White, W. A., 1970, The geomorphology of the Florida peninsula: Florida Geological Survey Bulletin 51, 164 p.

Wilson, W. E., 1977, Ground-water resources of De Soto and Hardee Counties, Florida: Florida Bureau of Geology Report of Investigations 83, $102 \mathrm{p}$. 
Wolansky, R. M., Barr, G. L., and Spechler, R. M., 1979, Configuration of the bottom of the Floridan aquifer, Southwest Florida Water Management District: U.S. Geological Survey Water-Resources Investigations Open-File Report 79-1490.

1980, Configuration of the top of the highly permeable dolomite zone of the Floridan aquifer, Southwest Florida Water Management District: U.S. Geological Survey Water-Resources Investigations Open-File Report 80-433.

Wolansky, R. M., and Garbade, J. M., 1981, Generalized thickness of the Floridan aquifer, Southwest Florida Water Management District: U.S. Geological Survey Water-Resources Investigations Open-File Report 80-1288.

Yobbi, D. K., Woodham, W. M., and Schiner, G. R., 1980a, Potentiometric surface of the Floridan aquifer, Southwest Florida Water Management District, May 1980: U.S. Geological Survey Open-File Report 80-587.

1980b, Potentiometric surface of the Floridan aquifer, Southwest Florida Water Management District, September 1980: U.S. Geological Survey OpenFile Report 80-1280. 
Table 6.--Chemical analyses of water from wells

[For location, see figure 12]

\begin{tabular}{|c|c|c|c|c|c|c|c|}
\hline $\begin{array}{l}\text { Well } \\
\text { No. }\end{array}$ & Station no. & $\begin{array}{l}\text { Date of } \\
\text { sample }\end{array}$ & $\begin{array}{l}\text { Depth } \\
\text { of we } 11 \\
\text { (feet) }\end{array}$ & $\begin{array}{l}\text { Depth of } \\
\text { casing } \\
\text { (feet) }\end{array}$ & $\begin{array}{l}\text { Elevation } \\
\text { of land } \\
\text { surface } \\
\text { (feet) }\end{array}$ & $\begin{array}{c}\text { Silica, } \\
\text { dis- } \\
\text { solved } \\
\left(\mathrm{mg}_{\mathrm{L}} \mathrm{L} \text { as }\right. \\
\left.\mathrm{SiO}_{2}\right)\end{array}$ & $\begin{array}{l}\text { Iron, } \\
\text { dis- } \\
\text { solved } \\
(\mu \mathrm{g} / \mathrm{L} \\
\text { as } \mathrm{Fe})\end{array}$ \\
\hline 1 & 282553082370201 & $6-25-80$ & 100 & - & 40 & 5.2 & 10 \\
\hline 2 & 282605082345801 & $5-21-80$ & 355 & 310 & 32 & 7.9 & -- \\
\hline 4 & 282636082221402 & $5-05-80$ & 16 & 6 & 103 & 5.0 & 460 \\
\hline 7 & 282742082375901 & $7-17-80$ & 580 & 445 & 15 & 6.4 & 10 \\
\hline 8 & 282756082311801 & $6-18-80$ & 335 & 113 & 60 & 5.2 & 0 \\
\hline 9 & 282838082284801 & $5-30-80$ & 400 & - & 72 & 7.7 & 70 \\
\hline 10 & 282849082232201 & $5-30-80$ & 230 & - & 190 & 8.5 & 20 \\
\hline 12 & 282932082253301 & $5-30-80$ & 275 & 65 & 80 & 8.7 & 520 \\
\hline 13 & 282938082332001 & $5-31-80$ & 380 & - & 32 & 5.9 & 230 \\
\hline 14 & 283038082352701 & $5-31-80$ & - & - & 30 & 8.1 & 0 \\
\hline 15 & 283127082355101 & $11-19-80$ & 55 & - & - & 8.5 & 0 \\
\hline 19 & 283143082281801 & $6-20-80$ & 116 & 80 & 84 & 7.1 & 0 \\
\hline 20 & 283201082315601 & $5-21-80$ & 259 & 176 & 36 & 6.6 & 50 \\
\hline 24 & 283240082335801 & $6-25-80$ & 245 & 217 & 30 & 6.8 & 10 \\
\hline 25 & 283243082365701 & $5-07-80$ & 302 & 277 & 7 & 10 & 2,800 \\
\hline 27 & 283258082231901 & $3-09-62$ & 602 & 478 & 133 & 11 & -- \\
\hline & & $2-19-80$ & - & - & - & 11 & -- \\
\hline & & $5-30-80$ & - & - & - & 10 & 10 \\
\hline 28 & 283258082232201 & $9-01-71$ & 757 & 300 & 133 & 10 & -- \\
\hline 29 & 283259082250101 & $5-30-80$ & 500 & - & 89 & 11 & 10 \\
\hline 30 & 283308082331901 & $6-18-80$ & 125 & - & 25 & 5.3 & 630 \\
\hline 32 & 283433082303801 & $5-31-80$ & 117 & 100 & - & 6.6 & 1 \\
\hline 33 & 283433082391301 & $6-18-80$ & 33 & 32 & 3 & 7.6 & 8,100 \\
\hline 35 & 283529082355801 & $5-16-80$ & 140 & 133 & 8 & 1.5 & 50 \\
\hline 37 & 283607082241501 & $5-30-80$ & - & - & 90 & - & -- \\
\hline 38 & 283637082313301 & $5-31-80$ & 145 & 42 & 45 & 7.3 & 0 \\
\hline 39 & 283648082275201 & $5-30-80$ & 250 & - & 126 & 13 & 10 \\
\hline 40 & 283658082292001 & $5-23-80$ & 190 & - & 60 & 9.3 & -- \\
\hline 41 & 283808082324801 & $6-18-80$ & 127 & - & 24 & 5.4 & 0 \\
\hline 42 & 283815082282201 & $6-26-80$ & 899 & 130 & 115 & 9.7 & 0 \\
\hline 44 & 283940082253201 & $5-30-80$ & 93 & - & 80 & 11 & 0 \\
\hline 46 & 284048082325001 & $5-31-80$ & - & - & 18 & 7.8 & 10 \\
\hline 47 & 284102082295001 & $6-19-80$ & 85 & - & 60 & 7.1 & 20 \\
\hline 48 & 284125082333401 & $6-26-80$ & 218 & 218 & 10 & 9.0 & 280 \\
\hline 49 & 284142082272101 & $5-30-80$ & 1.36 & 134 & 65 & 7.1 & 0 \\
\hline 51 & 284152082281801 & $5-30-80$ & 80 & - & 70 & 7.8 & 10 \\
\hline 53 & 284317082330601 & $5-05-80$ & 176 & - & 9 & 8.3 & 20 \\
\hline$* 54$ & 284317082330602 & $5-05-80$ & 46 & 40 & 9 & .2 & 310 \\
\hline 55 & 284339082245401 & $9-21-78$ & - & - & 232 & 7.6 & 10 \\
\hline 56 & 284339082270401 & $5-20-80$ & 169 & 168 & 33 & .8 & 30 \\
\hline
\end{tabular}

*Wells not in the Floridan aquifer. 
Table 6.--Chemical analyses of water from wells--Continued

\begin{tabular}{|c|c|c|c|c|c|c|c|}
\hline $\begin{array}{c}\text { Well } \\
\text { No. }\end{array}$ & Station no. & $\begin{array}{l}\text { Date of } \\
\text { sample }\end{array}$ & $\begin{array}{l}\text { Depth } \\
\text { of we } 11 \\
\text { (feet) }\end{array}$ & $\begin{array}{l}\text { Depth of } \\
\text { casing } \\
\text { (feet) }\end{array}$ & $\begin{array}{c}\text { Elevation } \\
\text { of land } \\
\text { surface } \\
\text { (feet) }\end{array}$ & $\begin{array}{c}\text { Silica, } \\
\text { dis- } \\
\text { solved } \\
(\mathrm{mg} / \mathrm{L} \text { as } \\
\left.\mathrm{SiO}_{2}\right) \\
\end{array}$ & $\begin{array}{l}\text { Iron, } \\
\text { dis- } \\
\text { solved } \\
\text { ( } \mu \mathrm{g} / \mathrm{L} \\
\text { as Fe) }\end{array}$ \\
\hline$* 57$ & 284339082270402 & $5-20-80$ & 41 & 36 & 33 & 6.4 & 26 \\
\hline 58 & 284412082313001 & $5-31-80$ & 107 & 80 & 70 & 7.9 & 10 \\
\hline \multirow[t]{2}{*}{59} & 284455082331601 & $1-12-71$ & 138 & - & 10 & 7.9 & -- \\
\hline & & $5-02-73$ & - & - & - & 6.6 & -- \\
\hline \multirow[t]{2}{*}{60} & 284501082331301 & $5-17-67$ & 140 & - & - & 12 & -- \\
\hline & & $5-02-73$ & - & - & - & 10 & -- \\
\hline 61 & 284532082371001 & $5-05-80$ & 45 & 39 & 4 & 7.4 & 3,400 \\
\hline \multirow[t]{2}{*}{62} & 284537082331401 & $1-12-71$ & 120 & - & - & 7.1 & -- \\
\hline & & $5-02-73$ & - & - & - & 6.9 & -- \\
\hline 64 & 284551082345301 & $5-05-80$ & 99 & - & 6 & 7.2 & -- \\
\hline 65 & 284705082270101 & $5-20-80$ & 63 & 59 & 58 & 1.7 & 30 \\
\hline 67 & 284722082315001 & $6-19-80$ & 200 & - & 38 & 7.2 & 0 \\
\hline 68 & 284803082351701 & $5-05-80$ & 50 & 44 & 5 & 7.4 & -- \\
\hline 69 & 284840082325501 & $6-25-80$ & - & - & 10 & 7.6 & 10 \\
\hline 70 & 284922082291801 & $6-26-80$ & 96 & 84 & 70 & 7.5 & 0 \\
\hline 73 & 284947082311801 & $5-05-80$ & 46 & 34 & 21 & .1 & -- \\
\hline 74 & 285010082384001 & $5-06-80$ & 55 & 49 & 3 & 6.4 & 180,000 \\
\hline 77 & 285112082354401 & $7-17-80$ & 111 & - & 3 & 5.2 & 10 \\
\hline 78 & 285116082351401 & $6-19-80$ & 100 & 70 & 4 & 6.4 & 10 \\
\hline 82 & 285234082341901 & $7-17-80$ & 252 & 240 & 6 & 9.7 & 0 \\
\hline 86 & 285254082323001 & $5-05-80$ & 30 & 20 & 8 & 5.4 & 950 \\
\hline 88 & 285356082352801 & $3-10-62$ & 152 & 100 & 4 & 7.4 & -- \\
\hline 89 & 285413082343201 & $5-25-80$ & 175 & 92 & 10 & 5.6 & 250 \\
\hline 90 & 285421082361601 & $5-06-80$ & 53 & 3 & 5 & 4.4 & 70 \\
\hline 91 & 285421082361602 & $5-06-80$ & 176 & 162 & 5 & 1.0 & 70 \\
\hline 93 & 285548082313801 & $9-22-78$ & 150 & - & 90 & 6.8 & 10 \\
\hline 94 & 285610082374501 & $5-24-80$ & 38 & - & 9 & 6.3 & 10 \\
\hline 96 & 285654082350101 & $2-01-79$ & 109 & - & 11 & 5.4 & 40 \\
\hline 97 & 285737082400601 & $5-06-80$ & 88 & 67 & 7 & 4.5 & 30 \\
\hline 98 & 285737082413001 & $5-06-80$ & 47 & 42 & 5 & 5.6 & 2,900 \\
\hline 99 & 285749082342901 & $5-24-80$ & 135 & - & 27 & 5.8 & 150 \\
\hline 100 & 285900082361501 & $5-23-80$ & 102 & - & 28 & 4.7 & 270 \\
\hline 101 & 285918082381001 & $6-30-70$ & 27 & - & 25 & 38 & -- \\
\hline 102 & 285935082410901 & $6-22-71$ & 28 & 20 & 10 & 3.6 & -- \\
\hline 103 & 290004082454101 & $6-19-80$ & 20 & - & 2 & 24 & 640 \\
\hline 104 & 290010082321601 & $10-19-78$ & 82 & - & 86 & 7.1 & 30 \\
\hline 105 & 290023082393601 & $6-22-71$ & 30 & 21 & 18 & 3.3 & -- \\
\hline \multirow[t]{2}{*}{106} & 290027082370701 & $7-13-71$ & 78 & 42 & 25 & 6.4 & -- \\
\hline & & $10-19-78$ & - & - & - & 6.0 & 360 \\
\hline 107 & 290047082414101 & $6-21-71$ & 30 & 8 & 10 & 6.4 & -- \\
\hline
\end{tabular}


Table 6.--Chemical analyses of water from wells--Continued

\begin{tabular}{|c|c|c|c|c|c|c|c|}
\hline $\begin{array}{c}\text { Well } \\
\text { No. }\end{array}$ & Station no. & $\begin{array}{l}\text { Date of } \\
\text { sample }\end{array}$ & $\begin{array}{l}\text { Depth } \\
\text { of well } \\
\text { (feet) }\end{array}$ & $\begin{array}{l}\text { Depth of } \\
\text { casing } \\
\text { (feet) }\end{array}$ & $\begin{array}{c}\text { Elevation } \\
\text { of land } \\
\text { surface } \\
\text { (feet) }\end{array}$ & $\begin{array}{l}\text { Silica, } \\
\text { dis- } \\
\text { solved } \\
(\mathrm{mg} / \mathrm{L} \text { as } \\
\left.\mathrm{SiO}_{2}\right)\end{array}$ & $\begin{array}{l}\text { Iron, } \\
\text { dis- } \\
\text { solved } \\
(\mu \mathrm{g} / \mathrm{L} \\
\text { as } \mathrm{Fe})\end{array}$ \\
\hline 108 & 290107082400501 & $6-22-71$ & 58 & 19 & 16 & 9.2 & -- \\
\hline 109 & 290112082371101 & $2-24-66$ & 125 & - & 25 & 7.8 & -- \\
\hline 110 & 290114082420901 & $6-23-71$ & 24 & 18 & 9 & 3.3 & -- \\
\hline \multirow[t]{2}{*}{111} & 290115082401001 & $7-13-71$ & 40 & - & 16 & 5.1 & -- \\
\hline & & $10-19-78$ & - & - & - & 4.9 & 50 \\
\hline 112 & 290117082404501 & $10-19-78$ & 150 & - & 12 & 4.1 & 80 \\
\hline \multirow[t]{6}{*}{113} & 290118082364101 & $2-28-66$ & 67 & 62 & 29 & 6.8 & -- \\
\hline & & $5-25-76$ & - & - & - & - & -- \\
\hline & & $9-28-76$ & - & - & - & - & -- \\
\hline & & $5-25-77$ & - & - & - & - & -- \\
\hline & & $9-14-77$ & - & - & - & - & -- \\
\hline & & $7-18-80$ & - & - & - & 6.1 & 5,100 \\
\hline 114 & 290128082392801 & $12-16-70$ & 60 & - & 16 & 4.8 & - \\
\hline 115 & 290138082371901 & $2-15-66$ & 64 & - & 31 & 8.1 & -- \\
\hline 117 & 290145082421901 & $7-03-71$ & 61 & 30 & 10 & 5.0 & -- \\
\hline \multirow[t]{2}{*}{119} & 290202082403901 & $7-13-71$ & 155 & - & 13 & 5.0 & -- \\
\hline & & $7-18-80$ & - & - & - & 4.5 & 160 \\
\hline \multirow[t]{2}{*}{120} & 290203082421301 & $6-24-71$ & 59 & 49 & 10 & 5.5 & -- \\
\hline & & $6-20-80$ & - & - & - & 4.9 & 310 \\
\hline 121 & 290203082421302 & $7-18-80$ & 7 & - & 6 & 4.5 & 160 \\
\hline \multirow[t]{2}{*}{122} & 290205082421201 & $6-24-71$ & 52 & - & 10 & 5.5 & -- \\
\hline & & $11-01-78$ & - & - & - & 5.2 & 280 \\
\hline 124 & 290402082384901 & $2-11-66$ & 37 & - & 42 & 3.4 & -- \\
\hline 125 & 290503082323101 & $5-24-80$ & 115 & - & 81 & 6.2 & 0 \\
\hline 126 & 290551082380901 & $2-10-66$ & 32 & - & 37 & 5.4 & -- \\
\hline 127 & 290700082381001 & $5-24-80$ & 121 & - & 40 & 3.3 & 170 \\
\hline 128 & 290743082541501 & $9-17-81$ & 780 & 299 & 74 & 11 & -- \\
\hline
\end{tabular}


Table 6.--Chemical analyses of water from wells--Continued

\begin{tabular}{|c|c|c|c|c|c|c|c|c|}
\hline $\begin{array}{c}\text { Well } \\
\text { No. }\end{array}$ & $\begin{array}{l}\text { Cal- } \\
\text { cium } \\
\text { dis- } \\
\text { solved } \\
\text { (mg/L } \\
\text { as Ca) }\end{array}$ & $\begin{array}{l}\text { Magne- } \\
\text { sium, } \\
\text { dis- } \\
\text { solved } \\
\text { (mg/L } \\
\text { as } \mathrm{Mg} \text { ) }\end{array}$ & $\begin{array}{l}\text { Sodium, } \\
\text { dis- } \\
\text { solved } \\
\text { (mg/L } \\
\text { as } \mathrm{Na} \text { ) }\end{array}$ & $\begin{array}{l}\text { Potas- } \\
\text { sium, } \\
\text { dis- } \\
\text { solved } \\
\text { (mg/L } \\
\text { as } \mathrm{K})\end{array}$ & $\begin{array}{l}\text { Alka- } \\
\text { linity, } \\
\text { field } \\
(\mathrm{mg} / \mathrm{L} \text { as } \\
\left.\mathrm{CaCO}_{3}\right)\end{array}$ & $\begin{array}{c}\text { Sul- } \\
\text { fate, } \\
\text { dis- } \\
\text { solved } \\
(\mathrm{mg} / \mathrm{L} \text { as } \\
\left.\mathrm{SO}_{4}\right)\end{array}$ & \begin{tabular}{|} 
Chlo- \\
ride, \\
dis- \\
solved \\
$(\mathrm{mg} / \mathrm{L}$ \\
as Cl)
\end{tabular} & $\begin{array}{l}\text { Fluo- } \\
\text { ride, } \\
\text { dis- } \\
\text { solved } \\
\text { (mg/L } \\
\text { as F) }\end{array}$ \\
\hline 1 & 28 & 1.1 & 3.0 & 0.3 & 64 & 4.7 & 4.5 & 0.1 \\
\hline 2 & 9 & .8 & 10 & 3.8 & 36 & 8.9 & 3.9 & .1 \\
\hline 4 & 24 & 3.6 & 7.8 & .2 & 82 & 4.0 & 6.3 & .2 \\
\hline 7 & 35 & 3.9 & 2.6 & .3 & 92 & 5.9 & 4.7 & .1 \\
\hline 8 & 16 & .7 & 2.1 & .1 & 43 & 1.8 & 3.4 & .1 \\
\hline 9 & 54 & 5.1 & 15 & .5 & 160 & 9.3 & 6.5 & .1 \\
\hline 10 & 86 & 1.7 & 4.0 & .2 & 210 & 1.6 & 6.5 & .1 \\
\hline 12 & 77 & 1.6 & 4.8 & .3 & 180 & .8 & 6.4 & .2 \\
\hline 13 & 48 & 2.6 & 2.8 & .2 & 130 & 1.5 & 4.8 & .1 \\
\hline 14 & 51 & 7.3 & 3.1 & .4 & 130 & 7.3 & 4.9 & .1 \\
\hline 15 & 39 & 6.6 & 4.0 & .2 & - & 7.1 & 6.0 & .1 \\
\hline 19 & 29 & 1.5 & 2.8 & .1 & 69 & .8 & 3.8 & .1 \\
\hline 20 & 35 & 8.2 & 5.5 & .5 & 140 & 4.5 & 5.6 & .1 \\
\hline 24 & 36 & 2.5 & 3.1 & .2 & 100 & 3.6 & 4.6 & .1 \\
\hline 25 & 38 & 23 & 52 & 9.9 & 130 & 19 & 100 & .2 \\
\hline 27 & 66 & 11 & 6.2 & .4 & - & 12 & 11 & .3 \\
\hline & 60 & 9.8 & 5.6 & .3 & 180 & 13 & 9.2 & .2 \\
\hline & 58 & 8.2 & 5.3 & .2 & 180 & 16 & 10 & .2 \\
\hline 28 & 61 & 10 & 5.4 & .3 & - & 11 & 9.0 & .2 \\
\hline 29 & 70 & 7.8 & 5.1 & .2 & 190 & 9.8 & 9.2 & .2 \\
\hline 30 & 41 & 5.2 & 4.8 & 1.5 & 120 & -- & 8.8 & 0 \\
\hline 32 & 37 & 2.7 & 2.7 & .1 & 90 & 3.9 & 4.2 & .1 \\
\hline 33 & 270 & 310 & 3,100 & 91 & 520 & 670 & 5,300 & .1 \\
\hline 35 & 25 & 6.5 & 35 & .8 & 85 & .1 & 52 & .1 \\
\hline 37 & 76 & -- & -- & -- & - & -- & -- & - \\
\hline 38 & 35 & 4.1 & 2.8 & .1 & 96 & 4.1 & 4.8 & .1 \\
\hline 39 & 48 & 11 & 3.7 & .2 & 150 & 7.8 & 5.4 & .3 \\
\hline 40 & 41 & 7.3 & 5.2 & .3 & 120 & 0 & 6.0 & .1 \\
\hline 41 & 26 & 2.2 & 3.1 & .1 & 65 & 1.1 & 5.0 & .1 \\
\hline 42 & 76 & 9.7 & 6.2 & -- & 210 & 7.9 & .4 & .2 \\
\hline 44 & 55 & 14 & 6.0 & .3 & 170 & 8.7 & 11 & .2 \\
\hline 46 & 31 & 2.7 & 3.0 & .3 & 95 & 1.5 & 4.8 & .1 \\
\hline 47 & 29 & 4.5 & 3.7 & .2 & 86 & 3.8 & 4.6 & .1 \\
\hline 48 & 42 & 9.6 & 3.3 & -- & 140 & 4.9 & 5.7 & - \\
\hline 49 & 39 & 2.5 & 4.1 & .1 & 93 & 2.0 & 5.0 & .1 \\
\hline 51 & 42 & 5.2 & 3.1 & .2 & 110 & 8.6 & 4.7 & .1 \\
\hline 53 & 38 & 8.3 & 4.7 & .2 & 130 & 7.5 & 8.0 & .2 \\
\hline$* 54$ & 13 & .4 & 3.5 & 1.2 & 49 & 1.0 & 3.7 & .1 \\
\hline 55 & 32 & 5.3 & 3.0 & .2 & 90 & 10 & 4.6 & .1 \\
\hline 56 & 9 & 2.3 & 3.7 & .4 & 30 & 1.2 & 5.6 & .1 \\
\hline
\end{tabular}


Table 6.--Chemical analyses of water from wells--Continued

\begin{tabular}{|c|c|c|c|c|c|c|c|c|}
\hline $\begin{array}{l}\text { Well } \\
\text { No. }\end{array}$ & $\begin{array}{l}\text { Cal- } \\
\text { cium } \\
\text { dis- } \\
\text { solved } \\
\text { (mg/L } \\
\text { as } \mathrm{Ca} \text { ) }\end{array}$ & $\begin{array}{l}\text { Magne- } \\
\text { sium, } \\
\text { dis- } \\
\text { solved } \\
\text { (mg/L } \\
\text { as } \mathrm{Mg} \text { ) }\end{array}$ & $\begin{array}{l}\text { Sodium, } \\
\text { dis- } \\
\text { solved } \\
\text { (mg/L } \\
\text { as } \mathrm{Na})\end{array}$ & $\begin{array}{l}\text { Potas- } \\
\text { sium, } \\
\text { dis- } \\
\text { solved } \\
\text { (mg/L } \\
\text { as K) }\end{array}$ & $\begin{array}{l}\text { Alka- } \\
\text { linity, } \\
\text { field } \\
(\mathrm{mg} / \mathrm{L} \text { as } \\
\left.\mathrm{CaCO}_{3}\right)\end{array}$ & $\begin{array}{c}\text { Sul- } \\
\text { fate, } \\
\text { dis- } \\
\text { solved } \\
(\mathrm{mg} / \mathrm{L} \text { as } \\
\left.\mathrm{SO}_{4}\right)\end{array}$ & $\begin{array}{c}\text { Chlo- } \\
\text { ride, } \\
\text { dis- } \\
\text { solved } \\
(\mathrm{mg} / \mathrm{L} \\
\text { as Cl) }\end{array}$ & $\begin{array}{l}\text { Fluo- } \\
\text { ride, } \\
\text { dis- } \\
\text { solved } \\
\text { (mg/L } \\
\text { as F) }\end{array}$ \\
\hline$* 57$ & 34 & 3.2 & 3.6 & 0.2 & 110 & 2.4 & 4.2 & 0.1 \\
\hline 58 & 37 & 4.8 & 3.2 & .1 & 100 & 5.1 & 5.4 & .1 \\
\hline \multirow[t]{2}{*}{59} & 36 & 5.1 & 2.6 & .3 & 107 & 0 & 4.1 & 0 \\
\hline & 39 & 4.4 & 2.4 & .3 & 110 & 2.4 & 4.1 & .2 \\
\hline \multirow[t]{2}{*}{60} & 35 & 14 & 4.3 & .9 & - & 9.2 & 6.0 & .2 \\
\hline & 36 & 14 & 4.2 & .9 & 135 & 10 & 5.2 & .3 \\
\hline 61 & 160 & 160 & 1,400 & 44 & - & -- & 2,300 & .1 \\
\hline \multirow[t]{2}{*}{62} & 80 & 1.5 & 7.0 & .3 & 197 & 5.6 & 14 & .1 \\
\hline & 88 & 2.4 & 6.2 & .3 & 208 & 5.6 & 7.8 & .1 \\
\hline 64 & 37 & 15 & 91 & 3.1 & 120 & 27 & 150 & .1 \\
\hline 65 & 21 & 2.3 & 4.7 & .5 & 73 & .1 & 4.4 & 0 \\
\hline 67 & 31 & 5.0 & 3.1 & .2 & 90 & 4.1 & 5.5 & .1 \\
\hline 68 & 42 & 9.3 & 53 & 1.4 & 110 & 15 & 100 & .1 \\
\hline 69 & 28 & 3.5 & 2.8 & .2 & 73 & 3.1 & 4.4 & .1 \\
\hline 70 & 35 & 3.1 & 2.9 & .1 & 93 & 2.2 & .3 & .1 \\
\hline 73 & 5 & .1 & 1.6 & .7 & 16 & 0 & .3 & .1 \\
\hline 74 & -- & 590 & 4,200 & 180 & 0 & 1,100 & 9,200 & .2 \\
\hline 77 & 17 & 16 & 130 & 29 & 68 & 28 & 220 & .1 \\
\hline 78 & 28 & 6.1 & 18 & .7 & 96 & 9.6 & 31 & .1 \\
\hline 82 & 14 & 6.7 & 37 & 11 & 63 & 9.0 & 49 & .3 \\
\hline 86 & 70 & 1.6 & 3.0 & .3 & 170 & 5.7 & 4.2 & .1 \\
\hline 88 & 26 & 6.1 & 2.8 & .1 & - & 16 & 3.0 & .2 \\
\hline 89 & 27 & 4.4 & 2.8 & .1 & 64 & 15 & 4.4 & .1 \\
\hline 90 & 75 & 14 & 57 & 2.3 & 200 & 22 & 100 & .1 \\
\hline 91 & 59 & -- & -- & -- & 89 & -- & 1,430 & .1 \\
\hline 93 & 29 & 4.5 & 3.0 & .2 & 81 & 9.8 & 3.8 & .1 \\
\hline 94 & 80 & 5.5 & 7.8 & .3 & 200 & 8.6 & 11 & .1 \\
\hline 96 & 44 & 6.4 & 2.7 & .2 & 110 & 11 & 4.9 & .1 \\
\hline 97 & -- & - & - & - & - & - & 16 & - \\
\hline 98 & 140 & 36 & 230 & 8.0 & 240 & 140 & 500 & .1 \\
\hline 99 & 25 & 7.3 & 4.0 & .2 & 90 & 2.7 & 4.8 & .1 \\
\hline 100 & 31 & 6.4 & 3.1 & .1 & 100 & 2.0 & 4.4 & .2 \\
\hline 101 & 42 & 9.8 & 3.6 & 1.0 & 136 & 4.8 & 8.0 & .3 \\
\hline 102 & 83 & 4.3 & 4.8 & .1 & 220 & 2.8 & 9.0 & .1 \\
\hline 103 & 418 & 140 & 1,300 & 44 & 810 & 220 & 2,300 & - \\
\hline 104 & 33 & 6.5 & 2.6 & .2 & 80 & 22 & 3.7 & .1 \\
\hline 105 & 114 & 6.3 & 3.2 & 0 & 269 & 45 & 7.0 & .1 \\
\hline \multirow[t]{2}{*}{106} & 52 & 17 & 6.7 & .2 & 197 & 4.8 & 14 & .1 \\
\hline & 59 & 20 & 6.7 & .5 & 190 & 13 & 12 & .1 \\
\hline 107 & 96 & 27 & 15 & .4 & 317 & 12 & 33 & .3 \\
\hline
\end{tabular}


Table 6.--Chemical analyses of water from wells--Continued

\begin{tabular}{|c|c|c|c|c|c|c|c|c|}
\hline $\begin{array}{l}\text { We11 } \\
\text { No. }\end{array}$ & $\begin{array}{l}\text { Cal- } \\
\text { cium } \\
\text { dis- } \\
\text { solved } \\
\text { (mg/L } \\
\text { as } \mathrm{Ca} \text { ) }\end{array}$ & $\begin{array}{l}\text { Magne- } \\
\text { sium, } \\
\text { dis- } \\
\text { solved } \\
\text { (mg/L } \\
\text { as } \mathrm{Mg} \text { ) }\end{array}$ & $\begin{array}{l}\text { Sodium, } \\
\text { dis- } \\
\text { solved } \\
\text { (mg/L } \\
\text { as } \mathrm{Na} \text { ) }\end{array}$ & $\begin{array}{l}\text { Potas- } \\
\text { sium, } \\
\text { dis- } \\
\text { solved } \\
\text { (mg/L } \\
\text { as K) }\end{array}$ & $\begin{array}{l}\text { Alka- } \\
\text { linity, } \\
\text { field } \\
(\mathrm{mg} / \mathrm{L} \text { as } \\
\left.\mathrm{CaCO}_{3}\right)\end{array}$ & $\begin{array}{c}\text { Sul- } \\
\text { fate, } \\
\text { dis- } \\
\text { solved } \\
\left(\mathrm{mg} / \mathrm{L} \text { as }_{\left.\mathrm{SO}_{4}\right)}\right.\end{array}$ & $\begin{array}{l}\text { Chlo- } \\
\text { ride, } \\
\text { dis- } \\
\text { solved } \\
\text { (mg/L } \\
\text { as CI) }\end{array}$ & $\begin{array}{l}\text { Fluo- } \\
\text { ride, } \\
\text { dis- } \\
\text { solved } \\
\text { (mg/L } \\
\text { as F) }\end{array}$ \\
\hline 108 & 77 & 12 & 3.4 & 0.5 & 239 & 4.8 & 7.0 & 0.2 \\
\hline 109 & 91 & 3.8 & 5.2 & .1 & - & 0 & 11 & .1 \\
\hline 110 & 73 & 34 & 4.8 & .1 & 318 & 9.6 & 8.0 & .4 \\
\hline \multirow[t]{2}{*}{111} & 69 & 15 & 4.5 & .2 & 226 & 8.0 & 9.0 & .3 \\
\hline & 83 & 18 & 9.6 & .3 & 240 & 21 & 16 & .2 \\
\hline 112 & 90 & 2.7 & 6.5 & .1 & 240 & 16 & 4.3 & .2 \\
\hline \multirow[t]{6}{*}{113} & 90 & 2.7 & 6.5 & .1 & - & 2.8 & 12 & .2 \\
\hline & 94 & 2.6 & -- & -- & - & -- & 11 & - \\
\hline & 92 & 2.6 & -- & -- & - & -- & 10 & - \\
\hline & 91 & 2.7 & -- & -- & - & -- & 11 & - \\
\hline & 85 & 2.6 & -- & -- & - & -- & 11 & - \\
\hline & 92 & 2.9 & 5.8 & .1 & 238 & .3 & 12 & 0 \\
\hline 114 & 135 & 2.4 & 7.4 & .7 & 277 & 68 & 10 & .2 \\
\hline 115 & 101 & 8.8 & 7.8 & 2 & - & 18 & 11 & .1 \\
\hline 117 & 101 & 3.2 & 4.9 & .2 & 269 & 2.4 & 9.0 & .1 \\
\hline \multirow{2}{*}{119} & 96 & 7.1 & 3.8 & .3 & 262 & 7.6 & 7.0 & .2 \\
\hline & 100 & 6.4 & 7.1 & .4 & 273 & 14 & 10 & .2 \\
\hline \multirow[t]{2}{*}{120} & 91 & 4.3 & 7.9 & .3 & 236 & 16 & 17 & .2 \\
\hline & 97 & 5.2 & 11 & .5 & 250 & 11 & 16 & .1 \\
\hline 121 & 100 & 6.4 & 7.1 & .4 & 273 & 14 & 10 & .2 \\
\hline \multirow{2}{*}{122} & 106 & 3.8 & 9.7 & .4 & 267 & 8.4 & 18 & .2 \\
\hline & 100 & 4.0 & 10 & .3 & 250 & 16 & 19 & .1 \\
\hline 124 & 55 & 28 & 1.8 & 0 & - & 0 & 6.0 & .2 \\
\hline 125 & 27 & 2.5 & 7.5 & .2 & 86 & 3.0 & 10 & .1 \\
\hline 126 & 66 & 18 & 4.3 & .2 & - & 3.6 & 10 & .2 \\
\hline 127 & 40 & 8.9 & 3.1 & .4 & 130 & 6.1 & 4.6 & .1 \\
\hline 128 & 59 & 18 & 4.0 & .4 & 230 & 2.2 & 7.2 & .1 \\
\hline
\end{tabular}


Table 6.--Chemical analyses of water from wells--Continued

\begin{tabular}{|c|c|c|c|c|c|c|c|c|c|}
\hline $\begin{array}{c}\text { Well } \\
\text { No. }\end{array}$ & $\begin{array}{l}\text { Nitro- } \\
\text { gen, } \\
\mathrm{NO}_{2}+\mathrm{NO}_{3} \\
\text { dis- } \\
\text { solved } \\
\text { (mg/L } \\
\text { as } \mathrm{N})\end{array}$ & $\begin{array}{l}\text { Phos- } \\
\text { pho- } \\
\text { rus, } \\
\text { dis- } \\
\text { solved } \\
\text { (mg/L } \\
\text { as P) }\end{array}$ & $\begin{array}{l}\text { Solids, } \\
\text { sum of } \\
\text { con- } \\
\text { stitu- } \\
\text { ents, } \\
\text { dis- } \\
\text { solved } \\
(\mathrm{mg} / \mathrm{L})\end{array}$ & $\begin{array}{l}\text { Hard- } \\
\text { ness } \\
(\mathrm{mg} / \mathrm{L} \\
\quad \text { as } \\
\left.\mathrm{CaCO}_{3}\right)\end{array}$ & $\begin{array}{l}\text { Hard- } \\
\text { ness } \\
\text { non- } \\
\text { carbo- } \\
\text { nate } \\
(\mathrm{mg} / \mathrm{L} \\
\text { as } \\
\left.\mathrm{CaCO}_{3}\right)\end{array}$ & $\begin{array}{c}\text { Spe- } \\
\text { cific } \\
\text { con- } \\
\text { duc- } \\
\text { tance } \\
\text { (umhos) }\end{array}$ & $\begin{array}{c}\mathrm{pH} \\
\text { (units) }\end{array}$ & $\begin{array}{l}\text { Tem- } \\
\text { pera- } \\
\text { ture } \\
\left({ }^{\circ} \mathrm{C}\right)\end{array}$ & $\begin{array}{l}\text { Stron- } \\
\text { tium, } \\
\text { dis- } \\
\text { solved } \\
\text { ( } \mu \text { g/L } \\
\text { as } \mathrm{Sr} \text { ) }\end{array}$ \\
\hline 1 & 1.00 & 0.01 & 90 & 75 & 11 & 184 & 7.0 & 26.5 & 60 \\
\hline 2 & .01 & .02 & 67 & 26 & 0 & 112 & - & 25.5 & 1,100 \\
\hline 4 & .50 & .03 & 103 & 75 & 0 & 187 & - & 21.5 & 30 \\
\hline 7 & .02 & .02 & 115 & 100 & 12 & 225 & - & 25.5 & 210 \\
\hline 8 & .47 & .01 & 57 & 43 & 0 & 113 & 7.6 & 25.5 & 2 \\
\hline 9 & .09 & .01 & 195 & 160 & 0 & 347 & 7.2 & 24.0 & 150 \\
\hline 10 & .02 & .03 & 235 & 220 & 12 & 408 & 7.4 & 25.5 & 80 \\
\hline 12 & .05 & .01 & 193 & 200 & 0 & 378 & 7.2 & 25.5 & 170 \\
\hline 13 & 0 & 0 & 133 & 130 & 0 & 265 & 7.6 & 25.5 & 140 \\
\hline 14 & .02 & .01 & 148 & 160 & 0 & 304 & 7.6 & 24.0 & 190 \\
\hline 15 & .02 & .01 & -- & -- & -- & 284 & 8.0 & 24.0 & 160 \\
\hline 19 & .06 & .02 & 87 & 79 & 10 & 160 & 7.4 & 26.0 & 70 \\
\hline 20 & .01 & 0 & 151 & 120 & 0 & 300 & - & 25.0 & 530 \\
\hline 24 & 12 & .01 & 118 & 100 & 0 & 229 & 7.7 & 25.0 & 90 \\
\hline 25 & 0 & .01 & 334 & 190 & 60 & 620 & - & 21.0 & 660 \\
\hline 27 & -- & -- & 233 & 210 & 20 & 410 & 7.8 & -- & -- \\
\hline & -- & -- & 218 & 190 & 10 & 385 & 7.3 & 23.0 & 230 \\
\hline & .43 & .03 & 218 & 180 & 0 & 402 & 7.5 & 26.0 & 200 \\
\hline 28 & -- & -- & 220 & 193 & 6 & 389 & 6.5 & -- & -- \\
\hline 29 & .34 & .02 & 218 & 210 & 0 & 398 & 7.6 & 26.0 & 210 \\
\hline 30 & 0 & .01 & 140 & 120 & 4 & 274 & 7.8 & 25.0 & 90 \\
\hline 32 & .80 & .01 & 114 & 100 & 14 & 205 & 7.7 & 25.0 & 100 \\
\hline 33 & .04 & .50 & 10,100 & 2,000 & 1,400 & 19,600 & 6.5 & 27.5 & 2,500 \\
\hline 35 & 0 & .01 & 173 & 90 & 5 & 368 & - & 24.0 & 450 \\
\hline 37 & -- & -- & -- & -- & -- & 421 & - & -- & -- \\
\hline 38 & .36 & .02 & 113 & 100 & 0 & 219 & 7.8 & 26.5 & 100 \\
\hline 39 & .20 & .02 & 172 & 170 & 0 & 321 & 7.6 & 26.0 & 120 \\
\hline 40 & .05 & .01 & 142 & 130 & 12 & 400 & 7.5 & 23.0 & 30 \\
\hline 41 & .53 & .01 & 84 & 74 & 9 & 171 & 7.8 & 28.0 & 50 \\
\hline 42 & .33 & -- & 239 & 230 & 20 & 456 & 7.3 & 23.5 & 270 \\
\hline 44 & .79 & 0 & 201 & 200 & 0 & 388 & 7.6 & 25.5 & 120 \\
\hline 46 & .05 & 0 & 109 & 89 & 0 & 206 & 7.6 & 27.5 & 70 \\
\hline 47 & .32 & .02 & 100 & 91 & 0 & 200 & 7.4 & 25.0 & 80 \\
\hline 48 & -- & -- & 160 & 140 & 5 & 297 & 7.6 & 24.5 & 120 \\
\hline 49 & 2.90 & .02 & 122 & 110 & 0 & 228 & 7.8 & 24.5 & 50 \\
\hline 51 & .22 & .01 & 129 & 130 & 0 & 250 & 7.7 & 24.0 & 100 \\
\hline 53 & .26 & .01 & 155 & 130 & 0 & 331 & 8.1 & 23.5 & 130 \\
\hline$* 54$ & .02 & 0 & 53 & 34 & 0 & 90 & - & 23.0 & 40 \\
\hline 55 & -- & -- & 117 & 100 & 12 & 222 & 7.8 & 25.0 & 180 \\
\hline 56 & 0 & 0 & 39 & 34 & 9 & 78 & - & 24.5 & 60 \\
\hline
\end{tabular}


Table 6.--Chemical analyses of water from wells--Continued

\begin{tabular}{|c|c|c|c|c|c|c|c|c|c|}
\hline $\begin{array}{l}\text { Well } \\
\text { No. }\end{array}$ & $\begin{array}{l}\text { Nitro- } \\
\text { gen, } \\
\mathrm{NO}_{2}+\mathrm{NO}_{3} \\
\text { dis- } \\
\text { solved } \\
\text { (mg/L } \\
\text { as } \mathrm{N} \text { ) }\end{array}$ & $\begin{array}{l}\text { Phos- } \\
\text { pho- } \\
\text { rus, } \\
\text { dis- } \\
\text { solved } \\
\text { (mg/L } \\
\text { as P) }\end{array}$ & $\begin{array}{l}\text { Solids, } \\
\text { sum of } \\
\text { con- } \\
\text { stitu- } \\
\text { ents, } \\
\text { dis- } \\
\text { solved } \\
\text { (mg/L) }\end{array}$ & $\begin{array}{l}\text { Hard- } \\
\text { ness } \\
(\mathrm{mg} / \mathrm{L} \\
\text { as } \\
\left.\mathrm{CaCO}_{3}\right)\end{array}$ & $\begin{array}{l}\text { Hard- } \\
\text { ness } \\
\text { non- } \\
\text { carbo- } \\
\text { nate } \\
(\mathrm{mg} / \mathrm{L} \\
\text { as } \\
\left.\mathrm{CaCO}_{3}\right)\end{array}$ & $\begin{array}{c}\text { Spe- } \\
\text { cific } \\
\text { con- } \\
\text { duc- } \\
\text { tance } \\
\text { (umhos) }\end{array}$ & $\begin{array}{c}\mathrm{pH} \\
\text { (units) }\end{array}$ & $\begin{array}{l}\text { Tem- } \\
\text { pera- } \\
\text { ture } \\
\left({ }^{\circ} \mathrm{C}\right)\end{array}$ & $\begin{array}{l}\text { Stron- } \\
\text { tium, } \\
\text { dis- } \\
\text { solved } \\
\text { ( } \mu \mathrm{g} / \mathrm{L} \\
\text { as } \mathrm{Sr} \text { ) }\end{array}$ \\
\hline$* 57$ & 0.14 & 0.04 & 121 & 98 & 0 & 245 & - & 25.5 & 90 \\
\hline 58 & .75 & .02 & 121 & 110 & 0 & 231 & 7.9 & 26.0 & 80 \\
\hline 59 & -- & -- & 121 & 110 & 4 & 215 & 8.4 & - & 100 \\
\hline & -- & -- & 125 & 120 & 6 & 225 & 7.5 & -- & 80 \\
\hline 60 & -- & -- & 164 & 150 & 9 & 308 & 8.1 & -- & 250 \\
\hline & -- & -- & 162 & 150 & 13 & 290 & 7.0 & -- & 250 \\
\hline 61 & .23 & 0 & -- & 1,100 & 830 & 8,320 & - & 21.5 & 1,400 \\
\hline 62 & -- & -- & 238 & 210 & 10 & 435 & 8.2 & -- & 1,100 \\
\hline & -- & -- & 242 & 230 & 21 & 415 & 7.4 & - & 20 \\
\hline 64 & .07 & .01 & 403 & 150 & 34 & 785 & - & 23.5 & 170 \\
\hline 65 & .01 & .01 & 79 & 62 & 0 & 167 & - & 25.0 & 60 \\
\hline 67 & .26 & .03 & 106 & 98 & 0 & 210 & 7.5 & 25.0 & 80 \\
\hline 68 & .14 & .03 & 295 & 140 & 33 & 581 & - & 23.0 & 120 \\
\hline 69 & .10 & -- & 94 & 84 & 11 & 175 & 8.0 & 23.0 & 70 \\
\hline 70 & .06 & -- & 112 & 100 & 7 & 207 & 7.8 & 23.5 & 80 \\
\hline 73 & 0 & 0 & 17 & 13 & 0 & 35 & - & 24.5 & 20 \\
\hline 74 & .02 & .01 & -- & -- & -- & 26,600 & - & 24.0 & 3,300 \\
\hline 77 & .01 & .01 & 487 & 110 & 41 & 912 & - & 24.5 & 300 \\
\hline 78 & .14 & .02 & 158 & 95 & 0 & 328 & 7.7 & 24.5 & 110 \\
\hline 82 & .01 & .01 & 177 & 65 & 2 & 302 & - & 25.0 & 2,000 \\
\hline 86 & .03 & .02 & 186 & 180 & 0 & 344 & - & 23.5 & 60 \\
\hline 88 & -- & -- & 105 & 90 & 18 & 80 & 7.9 & 23.0 & - \\
\hline 89 & .13 & .02 & 99 & 86 & 22 & 100 & - & -- & 100 \\
\hline 90 & .06 & .01 & 396 & 250 & 45 & 809 & - & 22.0 & 150 \\
\hline 91 & 0 & -- & -- & -- & -- & 4,800 & - & 22.0 & 380 \\
\hline 93 & -- & .02 & 106 & 91 & 10 & 192 & 7.6 & 24.0 & 160 \\
\hline 94 & .06 & - & 240 & 220 & 23 & 500 & 7.6 & 25.0 & 80 \\
\hline 96 & -- & -- & 151 & 140 & 30 & 280 & 7.2 & 24.0 & 7,200 \\
\hline 97 & 0 & 0 & -- & -- & -- & 459 & - & 21.0 & 140 \\
\hline 98 & .21 & .01 & 1,080 & 500 & 460 & 2,140 & - & 21.5 & 800 \\
\hline 99 & 0 & .02 & 104 & 93 & 3 & 201 & 7.4 & 24.0 & 40 \\
\hline 100 & 0 & .02 & 112 & 100 & 4 & 216 & 7.7 & 24.0 & 40 \\
\hline 101 & - & -- & 184 & 158 & 9 & 278 & 7.9 & 24.0 & 60 \\
\hline 102 & -- & -- & 240 & 230 & 5 & 430 & 7.9 & 23.0 & 90 \\
\hline 103 & 0 & -- & 4,700 & 1,000 & 220 & 8,500 & 6.6 & 22.0 & 1,400 \\
\hline 104 & -- & -- & 124 & 110 & 29 & 214 & 7.5 & 25.0 & 130 \\
\hline 105 & -- & -- & 341 & 310 & 42 & 580 & 8.1 & 22.5 & 110 \\
\hline \multirow[t]{2}{*}{106} & -- & -- & 220 & 200 & 3 & 392 & 8.0 & -- & 90 \\
\hline & -- & -- & 231 & 230 & 41 & 402 & 7.2 & 23.0 & 90 \\
\hline 107 & -- & -- & 380 & 350 & 34 & 700 & 8.1 & 22.5 & 90 \\
\hline
\end{tabular}


Table 6.--Chemical analyses of water from wells--Continued

\begin{tabular}{|c|c|c|c|c|c|c|c|c|c|}
\hline $\begin{array}{l}\text { We } 11 \\
\text { No. }\end{array}$ & $\begin{array}{c}\text { Nitro- } \\
\text { gen, } \\
\mathrm{NO}_{2}+\mathrm{NO}_{3} \\
\text { dis- } \\
\text { solved } \\
\text { (mg/L } \\
\text { as } \mathrm{N})\end{array}$ & $\begin{array}{l}\text { Phos- } \\
\text { pho- } \\
\text { rus, } \\
\text { dis- } \\
\text { solved } \\
\text { (mg/L } \\
\text { as P) }\end{array}$ & $\begin{array}{l}\text { Solids, } \\
\text { sum of } \\
\text { con- } \\
\text { stitu- } \\
\text { ents, } \\
\text { dis- } \\
\text { solved } \\
(\mathrm{mg} / \mathrm{L})\end{array}$ & $\begin{array}{l}\text { Hard- } \\
\text { ness } \\
(\mathrm{mg} / \mathrm{L} \\
\text { as } \\
\left.\mathrm{CaCO}_{3}\right)\end{array}$ & $\begin{array}{l}\text { Hard- } \\
\text { ness } \\
\text { non- } \\
\text { carbo- } \\
\text { nate } \\
(\mathrm{mg} / \mathrm{L} \\
\text { as } \\
\left.\mathrm{CaCO}_{3}\right) \\
\end{array}$ & $\begin{array}{c}\text { Spe- } \\
\text { cific } \\
\text { con- } \\
\text { duc- } \\
\text { tance } \\
\text { (umhos) }\end{array}$ & $\begin{array}{c}\mathrm{pH} \\
\text { (units) }\end{array}$ & $\begin{array}{l}\text { Tem- } \\
\text { pera- } \\
\text { ture } \\
\left({ }^{\circ} \mathrm{C}\right)\end{array}$ & $\begin{array}{l}\text { Stron- } \\
\text { tium, } \\
\text { dis- } \\
\text { solved } \\
\text { ( } \mu \mathrm{g} / \mathrm{L} \\
\text { as } \mathrm{Sr} \text { ) }\end{array}$ \\
\hline 108 & -- & -- & 259 & 240 & 2 & 448 & 8.2 & 24.0 & 170 \\
\hline 109 & -- & -- & 262 & 242 & 5 & 466 & 8.0 & 22.0 & -- \\
\hline 110 & -- & -- & 324 & 320 & 4 & 590 & 8.0 & 21.5 & 90 \\
\hline \multirow[t]{2}{*}{111} & -- & -- & 248 & 230 & 8 & 442 & 8.1 & 22.5 & 110 \\
\hline & -- & -- & 296 & 280 & 44 & 520 & 7.1 & 23.0 & 130 \\
\hline 112 & -- & -- & 275 & 280 & 45 & 469 & 6.9 & 24.0 & 140 \\
\hline \multirow[t]{6}{*}{113} & -- & -- & 255 & 236 & 12 & 424 & 7.9 & 22.0 & -- \\
\hline & -- & -- & -- & 250 & -- & 472 & 7.1 & 21.0 & -- \\
\hline & -- & -- & -- & 240 & -- & 454 & 6.9 & 21.5 & -- \\
\hline & -- & -- & -- & 240 & -- & 447 & 7.1 & 23.5 & -- \\
\hline & -- & -- & - & 220 & -- & 452 & 6.8 & 21.0 & -- \\
\hline & -- & 0.01 & 267 & 240 & 4 & 475 & 7.0 & 21.0 & 160 \\
\hline 114 & -- & -- & 395 & 350 & 70 & 663 & 7.4 & 22.0 & 2 \\
\hline 115 & -- & -- & 307 & 288 & 37 & 497 & 7.8 & 23.0 & -- \\
\hline 117 & -- & -- & 287 & 270 & 0 & 510 & 8.1 & 23.0 & 100 \\
\hline \multirow[t]{2}{*}{119} & -- & -- & 285 & 270 & 6 & 498 & 7.5 & 23.0 & 1 \\
\hline & -- & .03 & 307 & 280 & 3 & 525 & 7.3 & 23.0 & 160 \\
\hline \multirow[t]{2}{*}{120} & -- & -- & 284 & 250 & 9 & 483 & 8.1 & 23.0 & 1 \\
\hline & 0 & .29 & 296 & 260 & 14 & 500 & 7.3 & 25.0 & 110 \\
\hline 121 & .20 & .03 & 307 & 280 & 3 & 525 & 7.3 & 23.0 & 160 \\
\hline \multirow[t]{2}{*}{122} & -- & -- & 313 & 280 & 13 & 540 & 8.2 & 23.0 & 1 \\
\hline & -- & -- & 308 & 270 & 12 & 625 & 7.5 & 23.5 & 130 \\
\hline 124 & -- & -- & 241 & 252 & 8 & 459 & 7.9 & 24.0 & -- \\
\hline 125 & .17 & .05 & 109 & 78 & 0 & 191 & 7.4 & 24.0 & 90 \\
\hline 126 & -- & -- & 245 & 288 & 10 & 449 & 8.2 & 26.0 & -- \\
\hline 127 & .14 & .07 & 145 & 140 & 7 & 267 & 7.5 & 23.5 & 40 \\
\hline 128 & - & -- & -- & 220 & 0 & 431 & 7.5 & -- & 40 \\
\hline
\end{tabular}


Table 7.--Chemical analyses of water from springs and spring-fed rivers

[For location, see figure 4]

\begin{tabular}{|c|c|c|c|c|c|c|c|}
\hline $\begin{array}{l}\text { Site } \\
\text { No. }\end{array}$ & Station name & $\begin{array}{l}\text { Date of } \\
\text { sample }\end{array}$ & $\begin{array}{l}\text { Silica, } \\
\text { dis- } \\
\text { solved } \\
\text { (mg/L } \\
\text { as } \\
\mathrm{SiO}_{2} \text { ) }\end{array}$ & $\begin{array}{l}\text { Iron, } \\
\text { dis- } \\
\text { solved } \\
(\mu \mathrm{g} / \mathrm{L} \\
\text { as } \mathrm{Fe})\end{array}$ & $\begin{array}{l}\text { Cal- } \\
\text { cium, } \\
\text { dis- } \\
\text { solved } \\
\text { (mg/L } \\
\text { as } \mathrm{Ca} \text { ) }\end{array}$ & $\begin{array}{l}\text { Magne- } \\
\text { sium, } \\
\text { dis- } \\
\text { solved } \\
\text { (mg/L } \\
\text { as } \mathrm{Mg} \text { ) }\end{array}$ & $\begin{array}{l}\text { Sodium, } \\
\text { dis- } \\
\text { solved } \\
\text { (mg/L } \\
\text { as } \mathrm{Na} \text { ) }\end{array}$ \\
\hline \multirow[t]{2}{*}{1} & Unnamed spring & $\begin{array}{r}5-12-69 \\
8-04-69 \\
9-15-69 \\
10-27-69 \\
3-02-70\end{array}$ & $\begin{array}{l}7.2 \\
4.1 \\
6.8 \\
5.4 \\
6.3\end{array}$ & $\begin{array}{l}10 \\
-- \\
130 \\
-- \\
--\end{array}$ & $\begin{array}{l}72 \\
69 \\
72 \\
74 \\
76\end{array}$ & $\begin{array}{l}20 \\
29 \\
25 \\
30 \\
28\end{array}$ & $\begin{array}{l}155 \\
245 \\
249 \\
240 \\
240\end{array}$ \\
\hline & & $\begin{array}{l}4-13-70 \\
6-01-70\end{array}$ & $\begin{array}{l}4.5 \\
6.4\end{array}$ & $\begin{array}{l}-- \\
--\end{array}$ & $\begin{array}{l}69 \\
68\end{array}$ & $\begin{array}{l}24 \\
22\end{array}$ & $\begin{array}{l}207 \\
188\end{array}$ \\
\hline 2 & Boat Springs & $\begin{array}{r}4-30-64 \\
10-13-65\end{array}$ & $\begin{array}{l}6.8 \\
6.6\end{array}$ & $\begin{array}{r}0 \\
60\end{array}$ & $\begin{array}{l}44 \\
45 \\
28\end{array}$ & $\begin{array}{l}4.1 \\
3.8\end{array}$ & $\begin{array}{l}11 \\
8.0\end{array}$ \\
\hline 3 & Bobhill Springs & $\begin{array}{r}7-23-64 \\
10-13-64 \\
2-14-65 \\
8-06-65\end{array}$ & $\begin{array}{l}6.4 \\
6.8 \\
6.0 \\
6.4\end{array}$ & $\begin{array}{r}30 \\
160 \\
20 \\
0\end{array}$ & $\begin{array}{l}38 \\
37 \\
37 \\
40\end{array}$ & $\begin{array}{l}3.9 \\
2.8 \\
2.8 \\
2.4\end{array}$ & $\begin{array}{l}3.1 \\
3.2 \\
4.6 \\
2.9\end{array}$ \\
\hline \multirow[t]{2}{*}{4} & $\begin{array}{l}\text { Magnolia Springs } \\
\text { Run }\end{array}$ & $\begin{array}{l}4-30-64 \\
7-24-64\end{array}$ & $\begin{array}{l}5.6 \\
6.6\end{array}$ & $\begin{array}{l}-- \\
--\end{array}$ & $\begin{array}{l}43 \\
42\end{array}$ & $\begin{array}{l}5.2 \\
7.5\end{array}$ & $\begin{array}{l}29 \\
36\end{array}$ \\
\hline & Little Springs & $\begin{array}{r}10-13-64 \\
2-04-65 \\
8-05-65 \\
7-24-64 \\
8-06-65\end{array}$ & $\begin{array}{l}7.5 \\
7.2 \\
6.5 \\
8.7 \\
7.0\end{array}$ & $\begin{array}{r}240 \\
170 \\
60 \\
60 \\
0\end{array}$ & $\begin{array}{l}42 \\
39 \\
42 \\
47 \\
48\end{array}$ & $\begin{array}{l}6.6 \\
6.9 \\
5.6 \\
5.0 \\
4.5\end{array}$ & $\begin{array}{r}30 \\
25 \\
29 \\
3.0 \\
3.0\end{array}$ \\
\hline \multirow[t]{4}{*}{6} & $\begin{array}{l}\text { Weeki Wachee } \\
\text { Springs }\end{array}$ & $\begin{array}{l}6-20-61 \\
3-16-62 \\
4-25-62 \\
3-08-63 \\
3-28-63\end{array}$ & $\begin{array}{l}8.2 \\
8.2 \\
8.3 \\
8.6 \\
-\end{array}$ & $\begin{array}{l}-- \\
-- \\
-- \\
-- \\
--\end{array}$ & $\begin{array}{l}50 \\
47 \\
46 \\
47 \\
46\end{array}$ & $\begin{array}{l}3.6 \\
5.0 \\
6.1 \\
5.2 \\
6.1\end{array}$ & $\begin{array}{l}3.2 \\
3.2 \\
3.1 \\
2.9 \\
2.4\end{array}$ \\
\hline & & $\begin{array}{r}1-14-64 \\
3-02-64 \\
4-16-64 \\
9-24-64 \\
10-14-64\end{array}$ & $\begin{array}{l}7.9 \\
7.9 \\
8.1 \\
8.4 \\
8.7\end{array}$ & $\begin{array}{r}-- \\
-- \\
0 \\
0 \\
20\end{array}$ & $\begin{array}{l}46 \\
47 \\
44 \\
48 \\
48\end{array}$ & $\begin{array}{l}7.1 \\
5.5 \\
7.8 \\
3.9 \\
3.9\end{array}$ & $\begin{array}{l}3.0 \\
2.7 \\
3.0 \\
2.8 \\
3.1\end{array}$ \\
\hline & & $\begin{array}{r}5-01-68 \\
5-13-69 \\
5-13-69 \\
6-02-70 \\
10-01-70\end{array}$ & $\begin{array}{l}8.0 \\
9.0 \\
7.9 \\
8.3 \\
8.0\end{array}$ & $\begin{array}{l}10 \\
10 \\
10 \\
60 \\
10\end{array}$ & $\begin{array}{l}46 \\
48 \\
49 \\
41 \\
45\end{array}$ & $\begin{array}{l}5.6 \\
5.0 \\
8.3 \\
5.3 \\
5.1\end{array}$ & $\begin{array}{l}3.0 \\
3.2 \\
2.7 \\
2.9 \\
2.9\end{array}$ \\
\hline & & $\begin{array}{l}4-19-71 \\
4-28-71 \\
5-10-72 \\
5-10-72 \\
4-04-74\end{array}$ & $\begin{array}{l}- \\
8.0 \\
7.2 \\
- \\
8.2\end{array}$ & $\begin{array}{r}-- \\
0 \\
10 \\
- \\
10\end{array}$ & $\begin{array}{l}-- \\
43 \\
45 \\
-- \\
50\end{array}$ & $\begin{array}{l}-- \\
5.6 \\
5.0 \\
-- \\
6.0\end{array}$ & $\begin{array}{l}-- \\
2.7 \\
3.0 \\
-- \\
4.0\end{array}$ \\
\hline
\end{tabular}


Table 7.--Chemical analyses of water from springs and spring-fed rivers-Continued

\begin{tabular}{|c|c|c|c|c|c|c|c|}
\hline $\begin{array}{l}\text { Site } \\
\text { No. }\end{array}$ & Station name & $\begin{array}{l}\text { Date cf } \\
\text { sample }\end{array}$ & $\begin{array}{l}\text { Silica, } \\
\text { dis- } \\
\text { solved } \\
\text { (mg/L } \\
\text { as } \\
\mathrm{SiO}_{2} \text { ) }\end{array}$ & $\begin{array}{l}\text { Iron, } \\
\text { dis- } \\
\text { solved } \\
(\mu \mathrm{g} / \mathrm{L} \\
\text { as } \mathrm{Fe})\end{array}$ & $\begin{array}{l}\text { Cal- } \\
\text { cium, } \\
\text { dis- } \\
\text { solved } \\
\text { (mg/L } \\
\text { as } \mathrm{Ca} \text { ) }\end{array}$ & $\begin{array}{l}\text { Magne- } \\
\text { sium, } \\
\text { dis- } \\
\text { solved } \\
\text { (mg/L } \\
\text { as } \mathrm{Mg} \text { ) }\end{array}$ & $\begin{array}{l}\text { Sodium, } \\
\text { dis- } \\
\text { solved } \\
\text { (mg/L } \\
\text { as } \mathrm{Na})\end{array}$ \\
\hline \multirow[t]{2}{*}{6} & $\begin{array}{l}\text { Weeki Wachee } \\
\text { Springs }\end{array}$ & $\begin{array}{r}10-17-74 \\
10-24-75 \\
6-03-76 \\
9-17-76 \\
5-03-77\end{array}$ & $\begin{array}{l}8.1 \\
8.3 \\
8.3 \\
8.1 \\
8.1\end{array}$ & $\begin{array}{l}10 \\
10 \\
20 \\
10 \\
10\end{array}$ & $\begin{array}{l}40 \\
50 \\
47 \\
50 \\
51\end{array}$ & $\begin{array}{l}8.4 \\
5.7 \\
5.0 \\
5.5 \\
5.6\end{array}$ & $\begin{array}{l}3.3 \\
3.6 \\
3.3 \\
3.2 \\
3.0\end{array}$ \\
\hline & & $\begin{array}{r}10-13-77 \\
5-10-78 \\
10-25-78 \\
10-17-79 \\
6-26-80\end{array}$ & $\begin{array}{l}8.1 \\
7.9 \\
8.0 \\
8.4 \\
8.3\end{array}$ & $\begin{array}{r}10 \\
10 \\
20 \\
10 \\
0\end{array}$ & $\begin{array}{l}48 \\
47 \\
47 \\
46 \\
49\end{array}$ & $\begin{array}{l}5.4 \\
5.4 \\
5.4 \\
5.0 \\
5.6\end{array}$ & $\begin{array}{l}3.2 \\
4.5 \\
-- \\
3.3 \\
3.3\end{array}$ \\
\hline 7 & $\begin{array}{l}\text { Salt Springs } \\
\text { Chassahowitzka } \\
\text { River }\end{array}$ & $\begin{array}{l}4-23-64 \\
1-26-65 \\
8-06-65 \\
9-24-64 \\
9-01-67\end{array}$ & $\begin{array}{l}8.5 \\
8.1 \\
6.6 \\
7.1 \\
8.2\end{array}$ & $\begin{array}{r}0 \\
0 \\
10 \\
30 \\
--\end{array}$ & $\begin{array}{l}62 \\
52 \\
56 \\
47 \\
70\end{array}$ & $\begin{array}{l}49 \\
46 \\
43 \\
10 \\
76\end{array}$ & $\begin{array}{r}375 \\
264 \\
260 \\
25 \\
605\end{array}$ \\
\hline \multirow{4}{*}{9} & & $\begin{array}{l}9-14-67 \\
9-19-67 \\
5-01-68 \\
5-13-69 \\
8-05-69 \\
9-16-69\end{array}$ & $\begin{array}{l}8.2 \\
8.3 \\
7.1 \\
8.3 \\
5.7 \\
6.6\end{array}$ & $\begin{array}{c}-- \\
-- \\
90 \\
0 \\
-- \\
--\end{array}$ & $\begin{array}{l}64 \\
50 \\
53 \\
51 \\
65 \\
47\end{array}$ & $\begin{array}{l}58 \\
22 \\
27 \\
15 \\
44 \\
15\end{array}$ & $\begin{array}{r}449 \\
138 \\
165 \\
64 \\
305 \\
54\end{array}$ \\
\hline & & $\begin{array}{r}10-27-69 \\
4-14-70 \\
6-02-70 \\
9-30-70 \\
4-28-71\end{array}$ & $\begin{array}{l}8.5 \\
5.9 \\
8.4 \\
8.4 \\
7.8\end{array}$ & $\begin{array}{l}-- \\
-- \\
60 \\
20 \\
20\end{array}$ & $\begin{array}{l}50 \\
48 \\
46 \\
48 \\
49\end{array}$ & $\begin{array}{l}13 \\
12 \\
11 \\
16 \\
16\end{array}$ & $\begin{array}{c}1.4 \\
1.4 \\
1.2 \\
2.4 \\
76\end{array}$ \\
\hline & & $\begin{array}{r}10-05-71 \\
8-21-73 \\
4-03-74 \\
10-17-74 \\
4-18-75\end{array}$ & $\begin{array}{l}8.2 \\
8.7 \\
8.2 \\
7.9 \\
8.5\end{array}$ & $\begin{array}{l}30 \\
80 \\
30 \\
10 \\
10\end{array}$ & $\begin{array}{l}48 \\
52 \\
54 \\
44 \\
54\end{array}$ & $\begin{array}{l}13 \\
22 \\
29 \\
15 \\
19\end{array}$ & $\begin{array}{r}40 \\
150 \\
-- \\
66 \\
100\end{array}$ \\
\hline & Crab Creek & $\begin{array}{r}10-24-75 \\
9-17-76 \\
5-03-77 \\
10-13-77 \\
10-15-64\end{array}$ & $\begin{array}{l}8.6 \\
8.6 \\
7.8 \\
8.3 \\
10\end{array}$ & $\begin{array}{r}20 \\
20 \\
10 \\
10 \\
140\end{array}$ & $\begin{array}{l}52 \\
50 \\
53 \\
55 \\
60\end{array}$ & $\begin{array}{l}22 \\
13 \\
18 \\
21 \\
43\end{array}$ & $\begin{array}{r}120 \\
42 \\
85 \\
120 \\
310\end{array}$ \\
\hline 11 & Baird Creek & $\begin{array}{r}1-27-65 \\
8-05-65 \\
10-14-64 \\
1-27-65 \\
8-05-65\end{array}$ & $\begin{array}{c}8.8 \\
8.2 \\
64 \\
8.8 \\
5.3\end{array}$ & $\begin{array}{r}0 \\
10 \\
230 \\
0 \\
110\end{array}$ & $\begin{array}{l}60 \\
67 \\
88 \\
76 \\
74\end{array}$ & $\begin{array}{r}51 \\
70 \\
88 \\
83 \\
126\end{array}$ & $\begin{array}{l}360 \\
560 \\
610 \\
660 \\
988\end{array}$ \\
\hline
\end{tabular}


Table 7.--Chemical analyses of water from springs and spring-fed rivers-Continued

\begin{tabular}{|c|c|c|c|c|c|c|c|}
\hline $\begin{array}{l}\text { Site } \\
\text { No. }\end{array}$ & Station name & $\begin{array}{l}\text { Date of } \\
\text { sample }\end{array}$ & $\begin{array}{c}\text { Silica, } \\
\text { dis- } \\
\text { solved } \\
\text { (mg/L } \\
\text { as } \\
\text { SiO }_{2} \text { ) } \\
\end{array}$ & $\begin{array}{l}\text { Iron, } \\
\text { dis- } \\
\text { solved } \\
(\mu \mathrm{g} / \mathrm{L} \\
\text { as } \mathrm{Fe})\end{array}$ & $\begin{array}{l}\text { Cal- } \\
\text { cium, } \\
\text { dis- } \\
\text { solved } \\
\text { (mg/L } \\
\text { as } \mathrm{Ca} \text { ) }\end{array}$ & $\begin{array}{l}\text { Magne- } \\
\text { sium, } \\
\text { dis- } \\
\text { solved } \\
\text { (mg/L } \\
\text { as } \mathrm{Mg} \text { ) }\end{array}$ & $\begin{array}{l}\text { Sodium, } \\
\text { dis- } \\
\text { solved } \\
\text { (mg/L } \\
\text { as } \mathrm{Na} \text { ) }\end{array}$ \\
\hline 12 & Ruth Springs Run & $\begin{array}{r}7-21-64 \\
10-15-64\end{array}$ & $\begin{array}{l}9.2 \\
9.9\end{array}$ & $\begin{array}{r}60 \\
280\end{array}$ & $\begin{array}{l}54 \\
56\end{array}$ & $\begin{array}{l}28 \\
24\end{array}$ & $\begin{array}{l}162 \\
122\end{array}$ \\
\hline 13 & Potter Creek & $\begin{array}{l}7-21-64 \\
1-27-65 \\
8-05-65\end{array}$ & $\begin{array}{l}8.2 \\
8.3 \\
8.7\end{array}$ & $\begin{array}{r}140 \\
0 \\
30\end{array}$ & $\begin{array}{l}72 \\
48 \\
49\end{array}$ & $\begin{array}{l}55 \\
18 \\
22\end{array}$ & $\begin{array}{l}450 \\
114 \\
115\end{array}$ \\
\hline $\begin{array}{l}14 \\
15\end{array}$ & $\begin{array}{l}\text { Crawford Creek } \\
\text { Crawford Creek } \\
\text { Tributary }\end{array}$ & $\begin{array}{r}7-22-64 \\
7-22-64 \\
10-15-64 \\
1-27-65 \\
8-05-65\end{array}$ & $\begin{array}{c}8.9 \\
9.1 \\
12 \\
9.0 \\
7.7\end{array}$ & $\begin{array}{l}-- \\
-- \\
-- \\
-- \\
--\end{array}$ & $\begin{array}{l}65 \\
59 \\
60 \\
60 \\
55\end{array}$ & $\begin{array}{l}38 \\
25 \\
24 \\
27 \\
24\end{array}$ & $\begin{array}{l}245 \\
124 \\
128 \\
152 \\
115\end{array}$ \\
\hline 16 & Ryle Creek & $\begin{array}{r}7-21-64 \\
10-15-64\end{array}$ & $\begin{array}{l}8.5 \\
11\end{array}$ & $\begin{array}{r}300 \\
3,300\end{array}$ & $\begin{array}{l}140 \\
116\end{array}$ & $\begin{array}{l}224 \\
156\end{array}$ & $\begin{array}{l}1,850 \\
1,162\end{array}$ \\
\hline 17 & Homosassa Springs & $\begin{array}{r}5-01-56 \\
11-10-60 \\
3-02-64\end{array}$ & $\begin{array}{l}8.1 \\
8.5 \\
8.3\end{array}$ & $\begin{array}{l}-- \\
--\end{array}$ & $\begin{array}{l}54 \\
50 \\
52\end{array}$ & $\begin{array}{l}56 \\
37 \\
61\end{array}$ & $\begin{array}{l}-- \\
292 \\
425\end{array}$ \\
\hline & & $\begin{array}{l}3-27-64 \\
8-04-65 \\
5-19-66 \\
6-05-67 \\
5-02-68\end{array}$ & $\begin{array}{c}8.2 \\
- \\
8.2 \\
8.0 \\
8.2\end{array}$ & $\begin{array}{r}10 \\
0 \\
10 \\
0 \\
--\end{array}$ & $\begin{array}{l}60 \\
44 \\
55 \\
53 \\
50\end{array}$ & $\begin{array}{l}78 \\
38 \\
57 \\
52 \\
45\end{array}$ & $\begin{array}{l}505 \\
300 \\
-- \\
399 \\
322\end{array}$ \\
\hline & & $\begin{array}{l}5-12-69 \\
6-01-70 \\
4-20-71 \\
4-21-72 \\
9-19-72\end{array}$ & $\begin{array}{l}8.4 \\
8.3 \\
8.4 \\
8.2 \\
8.1\end{array}$ & $\begin{array}{c}10 \\
-- \\
-- \\
10 \\
--\end{array}$ & $\begin{array}{l}53 \\
54 \\
-- \\
48 \\
--\end{array}$ & $\begin{array}{c}59 \\
60 \\
-- \\
48 \\
--\end{array}$ & $\begin{array}{l}438 \\
410 \\
-- \\
340 \\
--\end{array}$ \\
\hline & & $\begin{array}{r}10-11-72 \\
1-08-75 \\
6-05-75 \\
5-04-76 \\
9-17-76\end{array}$ & $\begin{array}{l}7.2 \\
8.2 \\
8.2 \\
- \\
-\end{array}$ & $\begin{array}{l}-- \\
10 \\
10 \\
-- \\
--\end{array}$ & $\begin{array}{l}65 \\
47 \\
51 \\
-- \\
--\end{array}$ & $\begin{array}{r}86 \\
35 \\
45 \\
-- \\
--\end{array}$ & $\begin{array}{l}600 \\
320 \\
330 \\
-- \\
--\end{array}$ \\
\hline & & $\begin{array}{l}5-03-77 \\
9-01-77 \\
6-29-78 \\
9-06-78\end{array}$ & $\begin{array}{l}- \\
- \\
-\end{array}$ & $\begin{array}{l}-- \\
-- \\
-- \\
--\end{array}$ & $\begin{array}{l}-- \\
-- \\
-- \\
--\end{array}$ & $\begin{array}{l}-- \\
-- \\
-- \\
--\end{array}$ & $\begin{array}{l}-- \\
-- \\
-- \\
--\end{array}$ \\
\hline \multirow[t]{2}{*}{18} & $\begin{array}{l}\text { Southeast Fork } \\
\text { Homosassa Springs }\end{array}$ & $\begin{array}{l}5-19-66 \\
6-05-67\end{array}$ & $\begin{array}{l}7.2 \\
8.0\end{array}$ & $\begin{array}{l}0 \\
0\end{array}$ & $\begin{array}{l}34 \\
35\end{array}$ & $\begin{array}{l}8.0 \\
8.8\end{array}$ & $\begin{array}{l}27 \\
28\end{array}$ \\
\hline & & $\begin{array}{l}5-02-68 \\
5-12-69 \\
6-01-70 \\
4-20-71 \\
5-09-72\end{array}$ & $\begin{array}{l}7.5 \\
8.8 \\
7.4 \\
5.6 \\
-\end{array}$ & $\begin{array}{r}0 \\
10 \\
-- \\
-- \\
--\end{array}$ & $\begin{array}{l}37 \\
36 \\
38 \\
-- \\
--\end{array}$ & $\begin{array}{l}9.2 \\
8.3 \\
8.6 \\
-- \\
--\end{array}$ & $\begin{array}{l}24 \\
-- \\
-- \\
-- \\
--\end{array}$ \\
\hline
\end{tabular}


Table 7.--Chemical analyses of water from springs and spring-fed rivers-Continued

\begin{tabular}{|c|c|c|c|c|c|c|c|}
\hline $\begin{array}{l}\text { Site } \\
\text { No. }\end{array}$ & Station name & $\begin{array}{l}\text { Date of } \\
\text { sample }\end{array}$ & $\begin{array}{l}\text { Silica, } \\
\text { dis- } \\
\text { solved } \\
\text { (mg/L } \\
\text { as } \\
\mathrm{SiO}_{2} \text { ) }\end{array}$ & $\begin{array}{l}\text { Iron, } \\
\text { dis- } \\
\text { solved } \\
(\mu \mathrm{g} / \mathrm{L} \\
\text { as } \mathrm{Fe})\end{array}$ & $\begin{array}{l}\text { Cal- } \\
\text { cium, } \\
\text { dis- } \\
\text { solved } \\
\text { ( } \mathrm{mg} / \mathrm{L} \\
\text { as } \mathrm{Ca} \text { ) }\end{array}$ & $\begin{array}{l}\text { Magne- } \\
\text { sium, } \\
\text { dis- } \\
\text { solved } \\
\text { ( } \mathrm{mg} / \mathrm{L} \\
\text { as } \mathrm{Mg} \text { ) }\end{array}$ & $\begin{array}{l}\text { Sodium, } \\
\text { dis- } \\
\text { solved } \\
\text { (mg/L } \\
\text { as } \mathrm{Na} \text { ) }\end{array}$ \\
\hline \multirow[t]{13}{*}{18} & \multirow{13}{*}{$\begin{array}{l}\text { Southeast Fork } \\
\text { Homosassa Springs }\end{array}$} & $11-14-72$ & - & -- & -- & - & -- \\
\hline & & $5-01-73$ & - & -- & -- & -- & -- \\
\hline & & $12-13-73$ & - & -- & - & -- & -- \\
\hline & & $5-28-74$ & - & -- & -- & - & -- \\
\hline & & $9-17-74$ & - & -- & -- & -- & -- \\
\hline & & $4-28-75$ & - & - & -- & -- & -- \\
\hline & & $9-02-75$ & - & -- & - & -- & -- \\
\hline & & $5-04-76$ & - & - & -- & -- & -- \\
\hline & & $9-17-76$ & - & -- & -- & -- & -- \\
\hline & & $5-03-77$ & - & -- & - & -- & -- \\
\hline & & $9-02-77$ & - & -- & - & - & -- \\
\hline & & $6-29-78$ & - & - & -- & -- & -- \\
\hline & & $9-06-78$ & - & -- & -- & -- & -- \\
\hline \multirow[t]{2}{*}{19} & \multirow[t]{2}{*}{ Halls River } & $8-03-65$ & 4.2 & 100 & 24 & 27 & 168 \\
\hline & & $5-19-66$ & 7.3 & 0 & 54 & 51 & 400 \\
\hline \multirow[t]{3}{*}{20} & \multirow[t]{3}{*}{ Middle Springs } & $3-25-64$ & 7.9 & 10 & 33 & 4.0 & 8.0 \\
\hline & & $10-16-64$ & 7.5 & 0 & 33 & 3.3 & 4.7 \\
\hline & & $8-04-65$ & 7.7 & 20 & 34 & 3.2 & 6.0 \\
\hline \multirow{2}{*}{21} & \multirow{2}{*}{ Saragassa Canal } & $10-16-64$ & 8.5 & -- & 34 & 6.6 & 25 \\
\hline & & $8-03-65$ & 7.4 & - & 35 & 8.4 & 38 \\
\hline \multirow[t]{21}{*}{22} & \multirow[t]{21}{*}{ Crystal River } & $5-18-66$ & - & -- & 105 & 235 & 1,910 \\
\hline & & $5-19-67$ & 7.2 & 0 & 49 & 13 & 288 \\
\hline & & $5-02-68$ & 5.3 & 20 & 60 & 90 & 726 \\
\hline & & $5-31-68$ & 5.6 & 0 & 62 & 83 & 633 \\
\hline & & $5-12-69$ & 7.7 & 10 & 50 & 34 & 242 \\
\hline & & $6-13-69$ & .7 & -- & 105 & 228 & 1,950 \\
\hline & & $6-08-70$ & 7.3 & - & 46 & 44 & 340 \\
\hline & & $10-13-70$ & - & -- & -- & -- & -- \\
\hline & & $4-28-71$ & 5.6 & 10 & 48 & 40 & 320 \\
\hline & & $10-05-71$ & 6.4 & 30 & 120 & 210 & 1,400 \\
\hline & & $5-10-72$ & 5.2 & -- & 92 & 180 & 1,400 \\
\hline & & $9-20-72$ & 6.6 & -- & 180 & 400 & 3,500 \\
\hline & & $4-30-73$ & 6.3 & -- & 63 & 70 & 560 \\
\hline & & $10-18-73$ & 5.1 & -- & 63 & 110 & 580 \\
\hline & & $4-04-74$ & 4.5 & -- & 54 & 41 & 370 \\
\hline & & $10-17-74$ & 4.8 & -- & 38 & 34 & 250 \\
\hline & & $4-18-75$ & 6.7 & -- & 54 & 45 & 410 \\
\hline & & $10-24-75$ & 6.2 & -- & 66 & 85 & 700 \\
\hline & & $9-17-76$ & 5.4 & -- & 51 & 46 & 330 \\
\hline & & $5-03-77$ & 6.6 & -- & 52 & 48 & 380 \\
\hline & & $5-10-78$ & 7.2 & 10 & 47 & 42 & 320 \\
\hline
\end{tabular}


Table 7.--Chemical analyses of water from springs and spring-fed rivers-Continued

\begin{tabular}{|c|c|c|c|c|c|c|c|c|}
\hline $\begin{array}{l}\text { Site } \\
\text { No. }\end{array}$ & $\begin{array}{l}\text { Date of } \\
\text { sample }\end{array}$ & $\begin{array}{l}\text { Potas- } \\
\text { sium, } \\
\text { dis- } \\
\text { solved } \\
\text { (mg/L } \\
\text { as K) }\end{array}$ & $\begin{array}{l}\text { Alka- } \\
\text { linity, } \\
\text { field } \\
(\mathrm{mg} / \mathrm{L} \\
\text { as } \\
\left.\mathrm{CaCO}_{3}\right)\end{array}$ & $\begin{array}{l}\text { Sul- } \\
\text { fate, } \\
\text { dis- } \\
\text { solved } \\
\text { (mg/L } \\
\text { as } \\
\left.\mathrm{SO}_{4}\right)\end{array}$ & $\begin{array}{l}\text { Chlo- } \\
\text { ride, } \\
\text { dis- } \\
\text { solved } \\
\text { (mg/L } \\
\text { as C1) }\end{array}$ & $\begin{array}{l}\text { Fluo- } \\
\text { ride, } \\
\text { dis- } \\
\text { solved } \\
\text { (mg/L } \\
\text { as F) }\end{array}$ & $\begin{array}{l}\text { Nitro- } \\
\text { gen, } \\
\text { ni- } \\
\text { trate, } \\
\text { total } \\
\text { (mg/L } \\
\text { as } N \text { ) }\end{array}$ & $\begin{array}{l}\text { Phos- } \\
\text { phate, } \\
\text { ortho, } \\
\text { dis- } \\
\text { solved } \\
\text { (mg/L } \\
\text { as } \\
\mathrm{PO}_{4} \text { ) }\end{array}$ \\
\hline 1 & $\begin{array}{r}5-12-69 \\
8-04-69 \\
9-15-69 \\
10-27-69 \\
3-02-70\end{array}$ & $\begin{array}{l}5.2 \\
8.2 \\
8.9 \\
8.1 \\
8.3\end{array}$ & $\begin{array}{l}156 \\
154 \\
161 \\
161 \\
158\end{array}$ & $\begin{array}{l}42 \\
57 \\
62 \\
61 \\
62\end{array}$ & $\begin{array}{l}299 \\
445 \\
420 \\
430 \\
434\end{array}$ & $\begin{array}{l}0.1 \\
.2 \\
0 \\
.2 \\
.1\end{array}$ & $\begin{array}{r}0.00 \\
.50 \\
.10 \\
.40 \\
1.30\end{array}$ & $\begin{array}{c}-- \\
-- \\
-- \\
0.03 \\
--\end{array}$ \\
\hline 2 & $\begin{array}{r}4-13-70 \\
6-01-70 \\
4-30-64 \\
10-13-65\end{array}$ & $\begin{array}{r}7.5 \\
6.8 \\
.5 \\
1.1\end{array}$ & $\begin{array}{l}154 \\
162 \\
112 \\
120\end{array}$ & $\begin{array}{r}49 \\
29 \\
7.5 \\
7.6\end{array}$ & $\begin{array}{r}370 \\
340 \\
18 \\
12\end{array}$ & $\begin{array}{l}.2 \\
.1 \\
.1\end{array}$ & $\begin{array}{l}.70 \\
1.00 \\
0 \\
0\end{array}$ & $\begin{array}{l}-- \\
-- \\
-- \\
--\end{array}$ \\
\hline 3 & $\begin{array}{r}7-23-64 \\
10-13-64 \\
2-14-65 \\
8-06-65 \\
4-30-64\end{array}$ & $\begin{array}{l}.2 \\
.4 \\
.2 \\
0 \\
1.2\end{array}$ & $\begin{array}{l}102 \\
102 \\
102 \\
100 \\
109\end{array}$ & $\begin{array}{l}5.6 \\
4.8 \\
5.6 \\
5.2 \\
13\end{array}$ & $\begin{array}{l}6.4 \\
5.0 \\
5.0 \\
4.0 \\
52\end{array}$ & $\begin{array}{l}0 \\
0 \\
0 \\
.2 \\
.1 \\
.1\end{array}$ & $\begin{array}{l}0 \\
.10 \\
.40 \\
.20 \\
.20\end{array}$ & $\begin{array}{l}-- \\
-- \\
-- \\
-- \\
--\end{array}$ \\
\hline 5 & $\begin{array}{r}7-24-64 \\
10-13-64 \\
2-04-65 \\
8-05-65 \\
7-24-64\end{array}$ & $\begin{array}{r}1.0 \\
1.2 \\
.6 \\
1.8 \\
.3\end{array}$ & $\begin{array}{l}108 \\
108 \\
105 \\
108 \\
131\end{array}$ & $\begin{array}{r}17 \\
14 \\
12 \\
13 \\
6.4\end{array}$ & $\begin{array}{r}66 \\
54 \\
42 \\
53 \\
4.0\end{array}$ & $\begin{array}{l}.1 \\
.2 \\
.1 \\
.1 \\
.1\end{array}$ & $\begin{array}{l}.10 \\
.20 \\
0 \\
1.10 \\
0\end{array}$ & $\begin{array}{l}-- \\
-- \\
-- \\
-- \\
--\end{array}$ \\
\hline 6 & $\begin{array}{l}8-06-65 \\
6-20-61 \\
3-16-62 \\
4-25-62 \\
3-08-63\end{array}$ & $\begin{array}{l}.4 \\
.2 \\
- \\
- \\
.4\end{array}$ & $\begin{array}{l}131 \\
133 \\
130 \\
130 \\
133\end{array}$ & $\begin{array}{l}6.8 \\
5.6 \\
7.2 \\
6.4 \\
6.8\end{array}$ & $\begin{array}{c}5.0 \\
-- \\
4.5 \\
4.5 \\
5.5\end{array}$ & $\begin{array}{l}.1 \\
0 \\
.2 \\
.4\end{array}$ & $\begin{array}{l}.10 \\
.10 \\
.20 \\
0 \\
0\end{array}$ & $\begin{array}{l}-- \\
-- \\
-- \\
-- \\
.01\end{array}$ \\
\hline & $\begin{array}{l}3-28-63 \\
1-14-64 \\
3-02-64 \\
4-16-64 \\
9-24-64\end{array}$ & $\begin{array}{c}.3 \\
.2 \\
0 \\
.3 \\
.1\end{array}$ & $\begin{array}{l}131 \\
133 \\
130 \\
130 \\
133\end{array}$ & $\begin{array}{l}6.0 \\
6.4 \\
6.4 \\
6.4 \\
6.4\end{array}$ & $\begin{array}{l}6.0 \\
4.0 \\
4.8 \\
4.0 \\
4.0\end{array}$ & $\begin{array}{c}- \\
.1 \\
.2 \\
.2\end{array}$ & $\begin{array}{l}0 \\
0 \\
0 \\
.10 \\
0^{.10}\end{array}$ & $\begin{array}{l}0 \\
.07 \\
-- \\
-- \\
--\end{array}$ \\
\hline & $\begin{array}{r}10-14-64 \\
5-01-68 \\
5-13-69 \\
5-13-69 \\
6-02-70\end{array}$ & $\begin{array}{r}.3 \\
.2 \\
5.0 \\
1.1 \\
.4\end{array}$ & $\begin{array}{l}131 \\
139 \\
131 \\
131 \\
133\end{array}$ & $\begin{array}{c}6.8 \\
6.5 \\
9.6 \\
14 \\
4.8\end{array}$ & $\begin{array}{c}4.0 \\
6.0 \\
8.0 \\
46 \\
6.0\end{array}$ & $\begin{array}{l}0 \\
.2 \\
.1 \\
.1 \\
.2\end{array}$ & $\begin{array}{r}0 \\
1.10 \\
.10 \\
.10 \\
.10\end{array}$ & $\begin{array}{l}-- \\
.03 \\
-- \\
.03 \\
--\end{array}$ \\
\hline & $\begin{array}{r}10-01-70 \\
4-19-71 \\
4-28-71 \\
5-10-72 \\
5-10-72\end{array}$ & $\begin{array}{l}.2 \\
- \\
.3 \\
.2 \\
-\end{array}$ & $\begin{array}{r}127 \\
-- \\
126 \\
128 \\
137\end{array}$ & $\begin{array}{l}-- \\
-- \\
-- \\
8.0 \\
--\end{array}$ & $\begin{array}{l}7.4 \\
-- \\
8.0 \\
5.0 \\
--\end{array}$ & $\begin{array}{l}.1 \\
- \\
.1 \\
.1 \\
-\end{array}$ & $\begin{array}{l}.30 \\
-- \\
.20 \\
-- \\
--\end{array}$ & $\begin{array}{l}.03 \\
-- \\
.11 \\
-- \\
--\end{array}$ \\
\hline
\end{tabular}


Table 7.--Chemical analyses of water from springs and spring-fed rivers-Continued

\begin{tabular}{|c|c|c|c|c|c|c|c|c|}
\hline $\begin{array}{c}\text { Site } \\
\text { No. }\end{array}$ & $\begin{array}{l}\text { Date of } \\
\text { sample }\end{array}$ & $\begin{array}{l}\text { Potas- } \\
\text { sium, } \\
\text { dis- } \\
\text { solved } \\
\text { (mg/L } \\
\text { as K) }\end{array}$ & $\begin{array}{l}\text { Alka- } \\
\text { linity, } \\
\text { fiel.d } \\
\text { (mg/L } \\
\text { as } \\
\mathrm{CaCO}_{3} \text { ) }\end{array}$ & $\begin{array}{l}\text { Sul- } \\
\text { fate, } \\
\text { dis- } \\
\text { solved } \\
\text { (mg/L } \\
\text { as } \\
\mathrm{SO}_{4} \text { ) }\end{array}$ & $\begin{array}{l}\text { Chlo- } \\
\text { ride, } \\
\text { dis- } \\
\text { solved } \\
\text { (mg/L } \\
\text { as C1) }\end{array}$ & $\begin{array}{l}\text { Fluo- } \\
\text { ride, } \\
\text { dis- } \\
\text { solved } \\
\text { (mg/L } \\
\text { as F) }\end{array}$ & $\begin{array}{l}\text { Nitro- } \\
\text { gen, } \\
\text { ni- } \\
\text { trate, } \\
\text { total } \\
\text { (mg/L } \\
\text { as } \mathrm{N} \text { ) }\end{array}$ & $\begin{array}{l}\text { Phos- } \\
\text { phate, } \\
\text { ortho, } \\
\text { dis- } \\
\text { solved } \\
\text { (mg/L } \\
\text { as } \\
\mathrm{PO}_{4} \text { ) }\end{array}$ \\
\hline 6 & $\begin{array}{r}4-14-74 \\
10-17-74 \\
10-24-75 \\
6-03-76 \\
9-17-76\end{array}$ & $\begin{array}{r}0.6 \\
.1 \\
.3 \\
.3 \\
.3\end{array}$ & $\begin{array}{r}-- \\
131 \\
130 \\
130 \\
130\end{array}$ & $\begin{array}{l}7.4 \\
7.5 \\
6.9 \\
8.5 \\
7.7\end{array}$ & $\begin{array}{l}4.6 \\
5.2 \\
5.7 \\
5.2 \\
5.1\end{array}$ & $\begin{array}{r}0.1 \\
.2 \\
.1 \\
.2 \\
.1\end{array}$ & $\begin{array}{r}-. \\
0.09 \\
.11 \\
.13 \\
.21\end{array}$ & $\begin{array}{l}-- \\
0.01 \\
.01 \\
.02 \\
.02\end{array}$ \\
\hline & $\begin{array}{r}5-03-77 \\
10-13-77 \\
5-10-78 \\
10-25-78 \\
10-17-79\end{array}$ & $\begin{array}{r}.3 \\
.4 \\
.4 \\
.5 \\
.2\end{array}$ & $\begin{array}{l}130 \\
130 \\
130 \\
130 \\
120\end{array}$ & $\begin{array}{l}7.4 \\
6.8 \\
9.0 \\
7.6 \\
6.4\end{array}$ & $\begin{array}{l}5.2 \\
5.2 \\
9.0 \\
5.4 \\
5.0\end{array}$ & $\begin{array}{l}.1 \\
.1 \\
.1 \\
.1 \\
.1\end{array}$ & $\begin{array}{l}.09 \\
.10 \\
-- \\
-- \\
--\end{array}$ & $\begin{array}{l}.01 \\
.01 \\
.01 \\
-- \\
--\end{array}$ \\
\hline 7 & $\begin{array}{l}6-26-80 \\
4-23-64 \\
1-28-65 \\
8-06-65 \\
9-24-64\end{array}$ & $\begin{array}{r}14^{.2} \\
9.2 \\
9.8 \\
.9\end{array}$ & $\begin{array}{l}130 \\
125 \\
124 \\
128 \\
132\end{array}$ & $\begin{array}{c}6.6 \\
112 \\
72 \\
73 \\
10\end{array}$ & $\begin{array}{l}5.0 \\
680 \\
490 \\
490 \\
46\end{array}$ & $\begin{array}{l}.1 \\
.2 \\
.2 \\
.1 \\
.2\end{array}$ & $\begin{array}{r}. \\
.10 \\
1.40 \\
.50 \\
.20\end{array}$ & $\begin{array}{l}-- \\
-- \\
-- \\
--\end{array}$ \\
\hline & $\begin{array}{l}9-01-67 \\
9-14-67 \\
9-19-67 \\
5-01-68 \\
5-13-69\end{array}$ & $\begin{array}{l}22 \\
16 \\
4.8 \\
5.4 \\
2.5\end{array}$ & $\begin{array}{r}-- \\
-- \\
-- \\
139 \\
144\end{array}$ & $\begin{array}{r}154 \\
116 \\
38 \\
43 \\
22\end{array}$ & $\begin{array}{r}1,050 \\
790 \\
242 \\
302 \\
121\end{array}$ & $\begin{array}{l}.3 \\
.3 \\
.2 \\
.4 \\
.2\end{array}$ & $\begin{array}{l}-- \\
2.10 \\
1.00 \\
0 \\
.10\end{array}$ & $\begin{array}{l}-- \\
-- \\
-- \\
-01\end{array}$ \\
\hline & $\begin{array}{r}8-05-69 \\
9-16-69 \\
10-27-69 \\
4-14-70 \\
6-02-70\end{array}$ & $\begin{array}{r}13 \\
2.2 \\
1.7 \\
1.6 \\
1.6\end{array}$ & $\begin{array}{l}141 \\
138 \\
139 \\
141 \\
141\end{array}$ & $\begin{array}{l}82 \\
12 \\
-- \\
-- \\
--\end{array}$ & $\begin{array}{r}510 \\
93 \\
75 \\
74 \\
870\end{array}$ & $\begin{array}{l}.3 \\
.2 \\
.2 \\
.2 \\
.2\end{array}$ & $\begin{array}{l}0 \\
0 \\
.90 \\
.60 \\
.70\end{array}$ & $\begin{array}{l}-- \\
-- \\
-- \\
-- \\
.06\end{array}$ \\
\hline & $\begin{array}{r}9-30-70 \\
4-28-71 \\
10-05-71 \\
8-21-73 \\
4-03-74\end{array}$ & $\begin{array}{r}3.0 \\
2.9 \\
1.8 \\
4.5 \\
11\end{array}$ & $\begin{array}{l}139 \\
139 \\
144 \\
143 \\
146\end{array}$ & $\begin{array}{r}-- \\
24 \\
169 \\
34 \\
50\end{array}$ & $\begin{array}{r}135 \\
140 \\
79 \\
270 \\
340\end{array}$ & $\begin{array}{l}0 \\
0 \\
0 \\
.3 \\
.2 \\
.1\end{array}$ & $\begin{array}{l}.60 \\
.60 \\
.10 \\
.20 \\
--\end{array}$ & $\begin{array}{l}.06 \\
.07 \\
.07 \\
-- \\
--\end{array}$ \\
\hline & $\begin{array}{r}10-17-74 \\
4-18-75 \\
10-24-75 \\
9-17-76 \\
5-03-77\end{array}$ & $\begin{array}{l}2.3 \\
3.8 \\
4.2 \\
1.8 \\
3.6\end{array}$ & $\begin{array}{l}139 \\
143 \\
144 \\
138 \\
140\end{array}$ & $\begin{array}{l}22 \\
13 \\
35 \\
16 \\
27\end{array}$ & $\begin{array}{r}120 \\
800 \\
210 \\
82 \\
160\end{array}$ & $\begin{array}{l}.1 \\
.3 \\
.7 \\
.1 \\
.1\end{array}$ & $\begin{array}{l}.17 \\
.24 \\
.21 \\
.17 \\
.16\end{array}$ & $\begin{array}{l}.03 \\
.01 \\
.02 \\
.02 \\
.02\end{array}$ \\
\hline 10 & $\begin{array}{r}10-13-77 \\
10-15-64 \\
1-27-65 \\
8-05-65\end{array}$ & $\begin{array}{l}4.4 \\
11 \\
12 \\
21\end{array}$ & $\begin{array}{l}140 \\
138 \\
141 \\
144\end{array}$ & $\begin{array}{r}35 \\
78 \\
94 \\
148\end{array}$ & $\begin{array}{r}220 \\
560 \\
680 \\
1,040\end{array}$ & $\begin{array}{l}.1 \\
.3 \\
.3 \\
.2\end{array}$ & $\begin{array}{l}.18 \\
-- \\
-- \\
--\end{array}$ & $\begin{array}{l}.02 \\
-- \\
-- \\
--\end{array}$ \\
\hline
\end{tabular}


Table 7.--Chemical analyses of water from springs and spring-fed rivers-Continued

\begin{tabular}{|c|c|c|c|c|c|c|c|c|}
\hline $\begin{array}{l}\text { Site } \\
\text { No. }\end{array}$ & $\begin{array}{l}\text { Date of } \\
\text { sample }\end{array}$ & $\begin{array}{l}\text { Potas- } \\
\text { sium, } \\
\text { dis- } \\
\text { solved } \\
\text { (mg/L } \\
\text { as K) }\end{array}$ & $\begin{array}{l}\text { Alka- } \\
\text { linity, } \\
\text { field } \\
\text { (mg/L } \\
\text { as } \\
\mathrm{CaCO}_{3} \text { ) }\end{array}$ & $\begin{array}{l}\text { Sul- } \\
\text { fate, } \\
\text { dis- } \\
\text { solved } \\
\text { (mg/L } \\
\text { as } \\
\left.\mathrm{SO}_{4}\right)\end{array}$ & $\begin{array}{l}\text { Chlo- } \\
\text { ride, } \\
\text { dis- } \\
\text { solved } \\
\text { (mg/L } \\
\text { as C1) }\end{array}$ & $\begin{array}{l}\text { Fluo- } \\
\text { ride, } \\
\text { dis- } \\
\text { solved } \\
\text { (mg/L } \\
\text { as F) }\end{array}$ & $\begin{array}{l}\text { Nitro- } \\
\text { gen, } \\
\text { ni- } \\
\text { trate, } \\
\text { total } \\
\text { (mg/L } \\
\text { as } N \text { ) }\end{array}$ & $\begin{array}{l}\text { Phos- } \\
\text { phate, } \\
\text { ortho, } \\
\text { dis- } \\
\text { solved } \\
\text { (mg/L } \\
\text { as } \\
\mathrm{PO}_{4} \text { ) }\end{array}$ \\
\hline 12 & $\begin{array}{r}10-14-64 \\
1-27-65 \\
8-05-65 \\
7-21-64 \\
10-15-64\end{array}$ & $\begin{array}{r}125 \\
22 \\
37 \\
5.8 \\
5.2\end{array}$ & $\begin{array}{r}784 \\
139 \\
95 \\
141 \\
135\end{array}$ & $\begin{array}{l}2.1 \\
164 \\
272 \\
46 \\
36\end{array}$ & $\begin{array}{r}960 \\
1,160 \\
810 \\
301 \\
235\end{array}$ & $\begin{array}{r}1.0 \\
.3 \\
.3 \\
.2 \\
.2\end{array}$ & $\begin{array}{r}0.70 \\
.30 \\
.70 \\
.10 \\
.30\end{array}$ & $\begin{array}{l}-- \\
-- \\
-- \\
-- \\
--\end{array}$ \\
\hline $\begin{array}{l}14 \\
15\end{array}$ & $\begin{array}{l}7-21-64 \\
1-27-65 \\
8-05-65 \\
7-22-64 \\
7-27-64\end{array}$ & $\begin{array}{l}16 \\
3.3 \\
4.3 \\
9.2 \\
4.7\end{array}$ & $\begin{array}{l}144 \\
138 \\
136 \\
166 \\
167\end{array}$ & $\begin{array}{r}124 \\
129 \\
32 \\
66 \\
37\end{array}$ & $\begin{array}{l}790 \\
176 \\
210 \\
452 \\
232\end{array}$ & $\begin{array}{r}.1 \\
1.1 \\
.2 \\
.2 \\
.2\end{array}$ & $\begin{array}{l}.10 \\
.10 \\
.20 \\
.60 \\
.40\end{array}$ & $\begin{array}{l}-- \\
-- \\
-- \\
-- \\
--\end{array}$ \\
\hline 16 & $\begin{array}{r}10-15-64 \\
1-27-65 \\
8-05-65 \\
7-21-64 \\
10-15-64\end{array}$ & $\begin{array}{l}5.5 \\
5.2 \\
4.2 \\
67 \\
42\end{array}$ & $\begin{array}{l}162 \\
164 \\
151 \\
182 \\
180\end{array}$ & $\begin{array}{r}35 \\
41 \\
35 \\
460 \\
298\end{array}$ & $\begin{array}{r}248 \\
275 \\
215 \\
3,350 \\
2,300\end{array}$ & $\begin{array}{l}0 \\
.3 \\
.2 \\
.3 \\
.4\end{array}$ & $\begin{array}{r}.10 \\
.60 \\
.40 \\
4.80 \\
.10\end{array}$ & $\begin{array}{l}-- \\
-- \\
-- \\
-- \\
--\end{array}$ \\
\hline 17 & $\begin{array}{r}5-01-56 \\
11-10-60 \\
3-02-64 \\
3-27-64 \\
8-04-65\end{array}$ & $\begin{array}{l}10 \\
-- \\
16 \\
19 \\
12\end{array}$ & $\begin{array}{l}113 \\
103 \\
108 \\
108 \\
112\end{array}$ & $\begin{array}{r}95 \\
80 \\
109 \\
120 \\
84\end{array}$ & $\begin{array}{l}680 \\
500 \\
784 \\
976 \\
532\end{array}$ & $\begin{array}{l}- \\
.1 \\
.2 \\
.1 \\
.2\end{array}$ & $\begin{array}{c}.14 \\
1.20 \\
-- \\
-- \\
--\end{array}$ & $\begin{array}{l}-- \\
-- \\
-- \\
-- \\
0.12\end{array}$ \\
\hline & $\begin{array}{l}5-19-66 \\
6-05-67 \\
5-02-68 \\
5-12-69 \\
6-01-70\end{array}$ & $\begin{array}{l}18 \\
14 \\
12 \\
16 \\
16\end{array}$ & $\begin{array}{l}107 \\
105 \\
112 \\
108 \\
105\end{array}$ & $\begin{array}{r}111 \\
96 \\
84 \\
124 \\
105\end{array}$ & $\begin{array}{l}780 \\
720 \\
580 \\
780 \\
750\end{array}$ & $\begin{array}{l}.3 \\
- \\
.4 \\
.2 \\
.3\end{array}$ & $\begin{array}{l}-- \\
-- \\
-- \\
-- \\
.70\end{array}$ & $\begin{array}{l}0 \\
-- \\
-- \\
-- \\
.07\end{array}$ \\
\hline & $\begin{array}{r}4-20-71 \\
4-21-72 \\
9-19-72 \\
10-11-72 \\
1-08-75\end{array}$ & $\begin{array}{c}-- \\
12 \\
-- \\
20 \\
12\end{array}$ & $\begin{array}{r}-- \\
118 \\
-- \\
107 \\
101\end{array}$ & $\begin{array}{r}-- \\
84 \\
-- \\
150 \\
75\end{array}$ & $\begin{array}{r}-- \\
640 \\
850 \\
1,100 \\
520\end{array}$ & $\begin{array}{l}- \\
.2 \\
- \\
.2 \\
.2\end{array}$ & $\begin{array}{l}.60 \\
.20 \\
.02 \\
.30 \\
.31\end{array}$ & $\begin{array}{l}.08 \\
.02 \\
.02 \\
-- \\
--\end{array}$ \\
\hline & $\begin{array}{l}6-05-75 \\
5-04-76 \\
9-17-76 \\
5-03-77 \\
9-01-77\end{array}$ & $\begin{array}{l}13 \\
-- \\
-- \\
-- \\
--\end{array}$ & $\begin{array}{c}108 \\
-- \\
-- \\
-- \\
--\end{array}$ & $\begin{array}{l}91 \\
-- \\
-- \\
-- \\
--\end{array}$ & $\begin{array}{r}600 \\
580 \\
1,100 \\
820 \\
800\end{array}$ & $\begin{array}{l}.2 \\
- \\
- \\
-\end{array}$ & $\begin{array}{l}.19 \\
-- \\
-- \\
-- \\
--\end{array}$ & $\begin{array}{l}.02 \\
-- \\
-- \\
-- \\
--\end{array}$ \\
\hline 18 & $\begin{array}{l}6-29-78 \\
9-06-78 \\
5-19-66 \\
6-05-67 \\
5-02-68 \\
5-12-69\end{array}$ & $\begin{array}{r}-- \\
-- \\
.9 \\
1.1 \\
.9 \\
.7\end{array}$ & $\begin{array}{r}-- \\
-- \\
107 \\
108 \\
123 \\
108\end{array}$ & $\begin{array}{l}-- \\
-- \\
10 \\
11 \\
9.8 \\
9.6\end{array}$ & $\begin{array}{r}820 \\
700 \\
46 \\
50 \\
45 \\
34\end{array}$ & $\begin{array}{l}- \\
- \\
.3 \\
.3 \\
.2 \\
-\end{array}$ & $\begin{array}{l}-- \\
-- \\
.10 \\
.50 \\
.20 \\
0^{.20}\end{array}$ & $\begin{array}{l}-- \\
-- \\
.10 \\
-- \\
-- \\
.10\end{array}$ \\
\hline
\end{tabular}


Table 7.--Chemical analyses of water from springs and spring-fed rivers-Continued

\begin{tabular}{|c|c|c|c|c|c|c|c|c|}
\hline $\begin{array}{l}\text { Site } \\
\text { No. }\end{array}$ & $\begin{array}{l}\text { Date of } \\
\text { sample }\end{array}$ & $\begin{array}{l}\text { Potas- } \\
\text { sium, } \\
\text { dis- } \\
\text { solved } \\
\text { (mg/L } \\
\text { as K) }\end{array}$ & $\begin{array}{l}\text { Alka- } \\
\text { linity, } \\
\text { field } \\
\text { (mg/L } \\
\text { as } \\
\left.\mathrm{CaCO}_{3}\right)\end{array}$ & $\begin{array}{l}\text { Sul- } \\
\text { fate, } \\
\text { dis- } \\
\text { solved } \\
\text { (mg/L } \\
\text { as } \\
\left.\mathrm{SO}_{4}\right)\end{array}$ & $\begin{array}{l}\text { Ch1o- } \\
\text { ride, } \\
\text { dis- } \\
\text { solved } \\
\text { (mg/L } \\
\text { as C1) }\end{array}$ & $\begin{array}{l}\text { Fluo- } \\
\text { ride, } \\
\text { dis- } \\
\text { solved } \\
\text { (mg/L } \\
\text { as F) }\end{array}$ & $\begin{array}{l}\text { Nitro- } \\
\text { gen, } \\
\text { ni- } \\
\text { trate, } \\
\text { total } \\
\text { (mg/L } \\
\text { as } N)\end{array}$ & $\begin{array}{c}\text { Phos- } \\
\text { phate, } \\
\text { ortho, } \\
\text { dis- } \\
\text { solved } \\
\text { (mg/L } \\
\text { as } \\
\left.\mathrm{PO}_{4}\right)\end{array}$ \\
\hline \multirow[t]{16}{*}{18} & $6-01-70$ & 1.1 & 110 & 11 & 47 & 0.2 & 0.40 & 0.05 \\
\hline & $4-20-71$ & -- & -- & -- & -- & - & .30 & -- \\
\hline & $5-09-72$ & -- & -- & -- & 46 & - & -- & -- \\
\hline & $11-14-72$ & -- & -- & -- & 47 & - & -- & -- \\
\hline & $5-01-73$ & -- & -- & -- & 34 & - & -- & -- \\
\hline & $12-13-73$ & -- & -- & -- & 51 & - & - & -- \\
\hline & $5-28-74$ & -- & -- & -- & 73 & - & -- & -- \\
\hline & $9-17-74$ & -- & -- & -- & 120 & - & -- & -- \\
\hline & $4-28-75$ & -- & -- & -- & 49 & - & -- & -- \\
\hline & $9-02-75$ & -- & -- & -- & 77 & - & -- & -- \\
\hline & $5-04-76$ & -- & -- & -- & 59 & - & -- & -- \\
\hline & $9-17-76$ & -- & -- & -- & 89 & - & -- & -- \\
\hline & $5-03-77$ & -- & -- & -- & 130 & - & -- & -- \\
\hline & $9-02-77$ & -- & -- & -- & 59 & - & -- & -- \\
\hline & $6-29-78$ & -- & -- & -- & 48 & - & -- & -- \\
\hline & $9-06-78$ & -- & -- & -- & 35 & - & -- & -- \\
\hline \multirow[t]{2}{*}{19} & $8-03-65$ & 7.4 & 75 & 443 & 302 & .2 & .20 & -- \\
\hline & $5-19-66$ & 16 & 113 & 103 & 710 & .3 & 1.40 & -- \\
\hline \multirow[t]{3}{*}{20} & $3-25-64$ & .4 & 92 & 3.8 & 17 & .2 & 0 & -- \\
\hline & $10-16-64$ & .3 & 89 & 3.2 & 6.0 & 0 & 0 & -- \\
\hline & $8-04-65$ & .4 & 90 & 4.4 & 10 & .1 & 0 & -- \\
\hline \multirow[t]{2}{*}{21} & $10-16-64$ & 1.2 & 95 & 9.2 & 46 & 0 & 0 & -- \\
\hline & $8-03-65$ & 1.8 & 95 & 13 & 73 & .1 & .10 & -- \\
\hline \multirow[t]{21}{*}{22} & $5-18-66$ & 79 & 112 & 469 & 3,490 & .5 & 7.20 & .12 \\
\hline & $5-19-67$ & 9.7 & 102 & 64 & 455 & .3 & 0 & .05 \\
\hline & $5-02-68$ & 27 & 112 & 175 & 1,300 & .6 & 0 & -- \\
\hline & $5-31-68$ & 24 & 107 & 162 & 1,160 & .3 & 0 & -- \\
\hline & $5-12-69$ & 9.1 & 105 & 72 & 440 & .1 & 0 & -- \\
\hline & $6-13-69$ & 71 & 105 & 450 & 2,150 & .7 & 2.40 & .07 \\
\hline & $6-08-70$ & 13 & 103 & 83 & 600 & - & 0 & .08 \\
\hline & $10-13-70$ & -- & 104 & -- & -- & - & .10 & .07 \\
\hline & $4-28-71$ & 13 & 113 & 76 & 570 & .2 & 0 & .07 \\
\hline & $10-05-71$ & 74 & -- & 380 & 2,800 & .3 & 0 & .01 \\
\hline & $5-10-72$ & 30 & 104 & 340 & 2,600 & .3 & 0 & .02 \\
\hline & $9-20-72$ & 150 & 112 & .830 & 6,100 & .7 & 0 & -- \\
\hline & $4-30-73$ & 23 & 112 & 150 & 920 & .2 & 0 & .02 \\
\hline & $10-18-73$ & 1.0 & 109 & 220 & 1,100 & .1 & 0 & .02 \\
\hline & $4-04-74$ & 14 & 109 & 83 & 600 & .1 & 0 & .02 \\
\hline & $10-17-74$ & 11 & 103 & 67 & 450 & .1 & -- & .02 \\
\hline & $4-18-75$ & 16 & 107 & 110 & 780 & .1 & -- & -- \\
\hline & $10-24-75$ & 26 & 111 & 170 & 1,200 & .2 & -- & -- \\
\hline & $9-17-76$ & 15 & 99 & 84 & 620 & .1 & .10 & .02 \\
\hline & $5-03-77$ & 16 & -- & 89 & 670 & .1 & 0 & .03 \\
\hline & $5-10-78$ & 11 & 98 & 98 & 590 & .1 & -- & -- \\
\hline
\end{tabular}


Table 7.--Chemical analyses of water from springs and spring-fed rivers-Continued

\begin{tabular}{|c|c|c|c|c|c|c|c|c|}
\hline $\begin{array}{l}\text { Site } \\
\text { No. }\end{array}$ & $\begin{array}{l}\text { Date of } \\
\text { sample }\end{array}$ & $\begin{array}{l}\text { Solids, } \\
\text { sum of } \\
\text { consti- } \\
\text { tuents, } \\
\text { dis- } \\
\text { solved } \\
\text { (mg/L) }\end{array}$ & $\begin{array}{l}\text { Hard- } \\
\text { ness } \\
(\mathrm{mg} / \mathrm{L} \\
\text { as } \\
\left.\mathrm{CaCO}_{3}\right)\end{array}$ & $\begin{array}{l}\text { Hard- } \\
\text { ness, } \\
\text { non- } \\
\text { carbo- } \\
\text { nate } \\
(\mathrm{mg} / \mathrm{L} \\
\text { as } \\
\left.\mathrm{CaCO}_{3}\right)\end{array}$ & 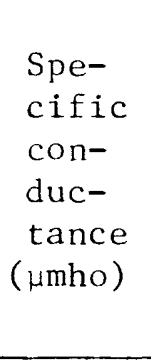 & $\begin{array}{c}\mathrm{pH} \\
\text { (units) }\end{array}$ & $\begin{array}{l}\text { Tem- } \\
\text { pera- } \\
\text { ture } \\
\left({ }^{\circ} \mathrm{C}\right)\end{array}$ & $\begin{array}{l}\text { Stron- } \\
\text { tium, } \\
\text { dis- } \\
\text { solved } \\
\text { ( } \mu \mathrm{g} / \mathrm{L} \\
\text { as } \mathrm{Sr} \text { ) }\end{array}$ \\
\hline \multirow[t]{7}{*}{1} & $5-12-69$ & -- & 262 & 106 & 1,280 & 8.0 & 22.0 & -- \\
\hline & $8-04-69$ & 686 & 292 & 138 & 1,800 & 7.6 & 24.5 & -- \\
\hline & $9-15-69$ & 951 & 283 & 123 & 1,800 & 7.7 & 24.0 & 490 \\
\hline & $10-27-69$ & 946 & 308 & 148 & 1,800 & 7.9 & 24.5 & -- \\
\hline & $3-02-70$ & 951 & 305 & 147 & 1,710 & 7.8 & 21.5 & -- \\
\hline & $4-13-70$ & 825 & 271 & 130 & 1,550 & 8.5 & 22.0 & -- \\
\hline & $6-01-70$ & 760 & 260 & 98 & 1,420 & 8.1 & 24.0 & -- \\
\hline \multirow[t]{2}{*}{2} & $4-30-64$ & -- & 127 & 16 & 353 & 8.5 & -- & -- \\
\hline & $10-13-65$ & 156 & 128 & 8 & 268 & 7.7 & -- & -- \\
\hline \multirow[t]{4}{*}{3} & $7-23-64$ & 125 & 111 & 10 & 240 & 6.9 & -- & -- \\
\hline & $10-13-64$ & 121 & 104 & 2 & 210 & 8.0 & -- & -- \\
\hline & $2-14-65$ & 123 & 104 & 2 & 200 & 7.5 & -- & -- \\
\hline & $8-06-65$ & 121 & 110 & 10 & 215 & 7.3 & -- & -- \\
\hline \multirow[t]{5}{*}{4} & $4-30-64$ & 221 & 129 & 20 & 388 & 8.2 & -- & -- \\
\hline & $7-24-64$ & 196 & 136 & 28 & 440 & 7.5 & -- & -- \\
\hline & $10-13-64$ & 217 & 132 & 24 & 393 & 7.8 & -- & -- \\
\hline & $2-04-65$ & -- & 126 & 21 & 348 & 7.5 & -- & -- \\
\hline & $8-05-65$ & -- & 128 & 20 & 395 & 7.5 & -- & -- \\
\hline \multirow[t]{2}{*}{5} & $7-24-64$ & 154 & 138 & 7 & 265 & 8.0 & 24.0 & -- \\
\hline & $8-06-65$ & 154 & 146 & 8 & 260 & 7.7 & -- & -- \\
\hline \multirow[t]{22}{*}{6} & $6-20-61$ & 155 & 140 & 7 & 270 & 8.2 & -- & -- \\
\hline & $3-16-62$ & 153 & 130 & 8 & 278 & 7.9 & 23.0 & -- \\
\hline & $4-25-62$ & 153 & 140 & 10 & 278 & 7.8 & - & -- \\
\hline & $3-08-63$ & 157 & 139 & 6 & 186 & 7.8 & 23.0 & -- \\
\hline & $3-28-63$ & 155 & 140 & 9 & 265 & 7.9 & - & -- \\
\hline & $1-14-64$ & 152 & 144 & 11 & 265 & 7.9 & 24.0 & -- \\
\hline & $3-02-64$ & 152 & 140 & 10 & 258 & 8.0 & 24.0 & -- \\
\hline & $4-16-64$ & 154 & 142 & 12 & 262 & 7.9 & - & -- \\
\hline & $9-24-64$ & 154 & 136 & 3 & 260 & 7.2 & -- & -- \\
\hline & $10-14-64$ & -- & 136 & 5 & 260 & 7.9 & -- & -- \\
\hline & $5-01-68$ & 161 & 138 & 0 & 282 & 7.5 & 24.0 & 170 \\
\hline & $5-13-69$ & 167 & 141 & 10 & 275 & 8.0 & 24.0 & -- \\
\hline & $5-13-69$ & 233 & 157 & 26 & 423 & 8.3 & 24.0 & -- \\
\hline & $6-02-70$ & 155 & 140 & 7 & 272 & 8.2 & 24.0 & 100 \\
\hline & $10-01-70$ & 150 & 136 & 9 & 282 & 8.2 & 23.5 & 200 \\
\hline & $4-19-71$ & -- & -- & -- & .282 & - & 22.5 & -- \\
\hline & $4-28-71$ & 147 & 130 & 5 & 270 & 7.9 & -- & 200 \\
\hline & $5-10-72$ & -- & 130 & 6 & 280 & 7.8 & 23.5 & 240 \\
\hline & $5-10-72$ & -- & -- & -- & 272 & 7.4 & 23.5 & -- \\
\hline & $4-14-74$ & 163 & 150 & 13 & 284 & 7.7 & 21.5 & 150 \\
\hline & $10-17-74$ & 152 & 130 & 3 & 267 & 7.4 & 24.0 & 180 \\
\hline & $10-24-75$ & 159 & 150 & 18 & 268 & 6.7 & 25.0 & 300 \\
\hline
\end{tabular}


Table 7.--Chemical analyses of water from springs and spring-fed rivers-Continued

\begin{tabular}{|c|c|c|c|c|c|c|c|c|}
\hline $\begin{array}{c}\text { Site } \\
\text { No. }\end{array}$ & $\begin{array}{l}\text { Date of } \\
\text { sample }\end{array}$ & $\begin{array}{l}\text { Solids, } \\
\text { sum of } \\
\text { consti- } \\
\text { tuents, } \\
\text { dis- } \\
\text { solved } \\
(\mathrm{mg} / \mathrm{L})\end{array}$ & $\begin{array}{l}\text { Hard- } \\
\text { ness } \\
(\mathrm{mg} / \mathrm{L} \\
\text { as } \\
\left.\mathrm{CaCO}_{3}\right)\end{array}$ & $\begin{array}{l}\text { Hard- } \\
\text { ness, } \\
\text { non- } \\
\text { carbo- } \\
\text { nate } \\
(\mathrm{mg} / \mathrm{L} \\
\text { as } \\
\left.\mathrm{CaCO}_{3}\right) \\
\end{array}$ & $\begin{array}{l}\text { Spe- } \\
\text { cific } \\
\text { con- } \\
\text { duc- } \\
\text { tance } \\
\text { (urho) }\end{array}$ & $\begin{array}{c}\mathrm{pH} \\
\text { (units) }\end{array}$ & $\begin{array}{l}\text { Tem- } \\
\text { pera- } \\
\text { ture } \\
\left({ }^{\circ} \mathrm{C}\right)\end{array}$ & $\begin{array}{l}\text { Stron- } \\
\text { tium, } \\
\text { dis- } \\
\text { solved } \\
(\mu \mathrm{g} / \mathrm{L} \\
\text { as } \mathrm{Sr} \text { ) }\end{array}$ \\
\hline \multirow[t]{8}{*}{6} & $6-03-76$ & 157 & 140 & 8 & 230 & 7.5 & 25.0 & 340 \\
\hline & $9-17-76$ & 158 & 150 & 18 & 290 & 7.4 & 26.5 & 200 \\
\hline & $5-03-77$ & 160 & 150 & 19 & 300 & 7.6 & 25.0 & 250 \\
\hline & $10-13-77$ & - & 140 & 11 & 277 & - & 23.0 & 130 \\
\hline & $5-10-78$ & -- & 140 & 9 & 300 & 7.9 & 24.0 & 170 \\
\hline & $10-25-78$ & 157 & 140 & 9 & 292 & 7.1 & 24.5 & 210 \\
\hline & $10-17-79$ & 147 & 140 & 16 & 276 & 7.6 & 24.0 & 170 \\
\hline & $6-26-80$ & 157 & 150 & 16 & 275 & 7.6 & 23.5 & 170 \\
\hline \multirow[t]{3}{*}{7} & $4-23-64$ & -- & 355 & 230 & 3,050 & 6.1 & - & - \\
\hline & $1-28-65$ & - & 282 & 158 & 1,500 & 7.5 & -- & -- \\
\hline & $8-06-65$ & 1,020 & 315 & 187 & 1,800 & 7.3 & -- & -- \\
\hline \multirow[t]{22}{*}{9} & $9-24-64$ & 225 & 160 & 28 & 419 & 7.4 & $\ldots$ & - \\
\hline & $9-01-67$ & 2,079 & 487 & 343 & - & 7.5 & -- & $\ldots$ \\
\hline & $9-14-67$ & 1,590 & 398 & 254 & 2,820 & 7.9 & -- & -- \\
\hline & $9-19-67$ & 521 & 216 & 72 & 1,100 & 7.6 & -- & -- \\
\hline & $5-01-68$ & 687 & 244 & 105 & 1,330 & 7.5 & 25.0 & 280 \\
\hline & $5-13-69$ & 371 & 189 & 45 & 721 & 7.9 & 25.0 & -- \\
\hline & $8-50-69$ & 1,090 & 343 & 215 & 2,150 & - & 24.0 & -- \\
\hline & $9-16-69$ & 321 & 179 & 55 & 590 & 8.4 & 24.0 & -- \\
\hline & $10-27-69$ & 290 & 179 & 39 & 545 & 7.7 & 24.0 & $\ldots$ \\
\hline & $4-14-70$ & 287 & 170 & 32 & 550 & 8.3 & 24.0 & -- \\
\hline & $6-02-70$ & 272 & 160 & 19 & 500 & 8.2 & 26.0 & 200 \\
\hline & $9-30-70$ & 394 & 189 & 49 & 735 & 8.2 & 25.0 & 220 \\
\hline & $4-28-71$ & 401 & 190 & 49 & 755 & 8.0 & 24.5 & 200 \\
\hline & $10-05-71$ & 294 & 170 & 30 & 530 & 8.1 & 24.5 & 200 \\
\hline & $8-21-73$ & 627 & 220 & 78 & 1,000 & 7.9 & 25.5 & 240 \\
\hline & $4-03-74$ & 770 & 250 & 110 & 1,420 & 7.7 & 24.5 & 300 \\
\hline & $10-17-74$ & 361 & 170 & 32 & 668 & 7.5 & 24.0 & 210 \\
\hline & $4-18-75$ & 1,110 & 210 & 71 & 875 & 5.5 & 24.5 & 250 \\
\hline & $10-24-75$ & 539 & 220 & 77 & 975 & 7.2 & 23.5 & 270 \\
\hline & $9-17-76$ & 297 & 180 & 41 & 555 & - & 26.0 & 200 \\
\hline & $5-03-77$ & 439 & 210 & 67 & 850 & 7.7 & 23.0 & 250 \\
\hline & $10-13-77$ & 548 & 220 & 85 & 990 & - & 21.0 & 200 \\
\hline \multirow[t]{3}{*}{10} & $10-15-64$ & 1,160 & 325 & 188 & 2,080 & 7.7 & - & -- \\
\hline & $1-27-65$ & 1,350 & 360 & 219 & 2,100 & 7.5 & - & -- \\
\hline & $8-05-65$ & 2,000 & 455 & 311 & 3,550 & 7.8 & -- & -- \\
\hline \multirow[t]{3}{*}{11} & $10-14-64$ & 2,410 & 582 & 0 & 4,000 & 7.4 & -- & -- \\
\hline & $1-27-65$ & 2,260 & 530 & 392 & 3,100 & 7.8 & -- & -- \\
\hline & $8-05-65$ & 3,370 & 702 & 608 & 6,000 & 7.2 & -- & -- \\
\hline \multirow[t]{2}{*}{12} & $7-21-64$ & 691 & 248 & 107 & 300 & 7.4 & 23.0 & -- \\
\hline & $10-15-64$ & 564 & 240 & 80 & 1,000 & 7.8 & - & -- \\
\hline 13 & $7-21-64$ & 1,602 & 405 & 261 & - & - & -- & -- \\
\hline
\end{tabular}


Table 7.--Chemical analyses of water from springs and spring-fed rivers-Continued

\begin{tabular}{|c|c|c|c|c|c|c|c|c|}
\hline $\begin{array}{l}\text { Site } \\
\text { No. }\end{array}$ & $\begin{array}{l}\text { Date of } \\
\text { sample }\end{array}$ & $\begin{array}{l}\text { Solids, } \\
\text { sum of } \\
\text { consti- } \\
\text { tuents, } \\
\text { dis- } \\
\text { solved } \\
(\mathrm{mg} / \mathrm{L})\end{array}$ & $\begin{array}{l}\text { Hard- } \\
\text { ness } \\
(\mathrm{mg} / \mathrm{L} \\
\text { as } \\
\left.\mathrm{CaCO}_{3}\right)\end{array}$ & $\begin{array}{l}\text { Hard- } \\
\text { ness, } \\
\text { non- } \\
\text { carbo- } \\
\text { nate } \\
(\mathrm{mg} / \mathrm{L} \\
\text { as } \\
\left.\mathrm{CaCO}_{3}\right) \\
\end{array}$ & $\begin{array}{l}\text { Spe- } \\
\text { cific } \\
\text { con- } \\
\text { duc- } \\
\text { tance } \\
\text { ( } \mu \text { mho) }\end{array}$ & $\begin{array}{c}\mathrm{pH} \\
\text { (units) }\end{array}$ & $\begin{array}{l}\text { Tem- } \\
\text { pera- } \\
\text { ture } \\
\left({ }^{\circ} \mathrm{C}\right)\end{array}$ & $\begin{array}{l}\text { Stron- } \\
\text { tium, } \\
\text { dis- } \\
\text { solved } \\
(\mu g / L \\
\text { as } S r)\end{array}$ \\
\hline \multirow[t]{2}{*}{13} & $1-27-65$ & 481 & 196 & 58 & 2,820 & 7.7 & -- & -- \\
\hline & $8-05-65$ & 523 & 214 & 78 & 770 & 7.5 & -- & -- \\
\hline 14 & $7-22-64$ & 986 & 318 & 152 & 1,780 & 7.6 & -- & -- \\
\hline \multirow[t]{4}{*}{15} & $7-27-64$ & 591 & 248 & 81 & 1,050 & 7.7 & -- & -- \\
\hline & $10-15-64$ & 555 & 250 & 88 & 1,050 & 7.9 & -- & -- \\
\hline & $1-27-65$ & 669 & 260 & 96 & 1,080 & 7.7 & -- & -- \\
\hline & $8-05-65$ & $\therefore 548$ & 234 & 83 & 988 & 7.8 & -- & - \\
\hline \multirow[t]{2}{*}{16} & $7-21-64$ & 6,210 & 1,270 & 1,090 & 9,700 & 7.0 & -- & -- \\
\hline & $10-15-64$ & 4,480 & 930 & 750 & 6,500 & 7.5 & -- & -- \\
\hline \multirow[t]{22}{*}{17} & $5-01-56$ & 1,330 & 365 & 254 & 2,590 & 7.6 & -- & -- \\
\hline & $11-10-60$ & 1,050 & 277 & 174 & 1,940 & - & -- & -- \\
\hline & $3-02-64$ & 1,500 & 380 & 272 & 2,750 & 7.4 & - & -- \\
\hline & $3-27-64$ & 1,830 & 470 & 362 & 3,390 & 7.3 & -- & -- \\
\hline & $8-04-65$ & 1,100 & 266 & 155 & 1,920 & 7.2 & - & -- \\
\hline & $5-19-66$ & 1,520 & 372 & 265 & 2,900 & 7.5 & -- & -- \\
\hline & $6-05-67$ & 1,410 & 346 & 242 & 2,600 & 7.3 & 23.0 & 500 \\
\hline & $5-02-68$ & 1,170 & 310 & 198 & 2,220 & 7.4 & 24.0 & 440 \\
\hline & $5-12-69$ & 1,540 & 375 & 267 & 2,900 & 7.5 & 24.0 & -- \\
\hline & $6-01-70$ & 1,470 & 382 & 277 & 2,550 & 8.0 & - & -- \\
\hline & $4-20-71$ & -- & -- & -- & 2,100 & - & 23.0 & -- \\
\hline & $4-21-72$ & 1,250 & 320 & 200 & 2,370 & 6.9 & 23.5 & 490 \\
\hline & $9-19-72$ & -- & - & - & 3,100 & - & 24.0 & -- \\
\hline & $10-11-72$ & 2,100 & 480 & 370 & 3,740 & 7.9 & 23.5 & 500 \\
\hline & $1-08-75$ & 1,100 & 260 & 160 & 2,530 & - & 22.5 & 460 \\
\hline & $6-05-75$ & 1,200 & 310 & 200 & 2,260 & 7.8 & 25.0 & 440 \\
\hline & $5-04-76$ & - & - & -- & 2,300 & - & 24.0 & - \\
\hline & $9-17-76$ & -- & - & -- & 3,650 & - & 25.5 & - \\
\hline & $5-03-77$ & -- & - & - & 1,220 & - & 25.0 & - \\
\hline & $9-01-77$ & -- & -- & - & 3,200 & - & 25.5 & - \\
\hline & $6-29-78$ & - & -- & -- & 3,000 & 7.6 & 23.5 & -- \\
\hline & $9-06-78$ & - & - & -- & 1,500 & 7.7 & 23.0 & - \\
\hline \multirow[t]{10}{*}{18} & $5-19-66$ & 199 & 118 & 10 & 351 & 8.0 & -- & -- \\
\hline & $6-05-67$ & 208 & 124 & 16 & 386 & 7.2 & 25.5 & -- \\
\hline & $5-02-68$ & 208 & 130 & 7 & 368 & 7.5 & 24.0 & 60 \\
\hline & $5-12-69$ & 183 & 124 & 16 & 335 & 7.9 & 25.0 & -- \\
\hline & $6-01-70$ & 206 & 131 & 21 & 375 & 8.4 & 24.0 & -- \\
\hline & $4-20-71$ & - & - & -- & 371 & - & 24.0 & -- \\
\hline & $5-09-72$ & - & -- & -- & 372 & - & 24.0 & - \\
\hline & $11-14-72$ & -- & -- & -- & 380 & - & 23.0 & -- \\
\hline & $5-01-73$ & - & - & -- & 332 & - & 22.0 & -- \\
\hline & $12-13-73$ & -- & - & - & 400 & - & 21.0 & - \\
\hline
\end{tabular}


Table 7.--Chemical analyses of water from springs and spring-fed rivers-Continued

\begin{tabular}{|c|c|c|c|c|c|c|c|c|}
\hline $\begin{array}{l}\text { Site } \\
\text { No. }\end{array}$ & $\begin{array}{l}\text { Date of } \\
\text { sample }\end{array}$ & $\begin{array}{l}\text { Solids, } \\
\text { sum of } \\
\text { consti- } \\
\text { tuents, } \\
\text { dis- } \\
\text { solved } \\
(\mathrm{mg} / \mathrm{L})\end{array}$ & $\begin{array}{l}\text { Hard- } \\
\text { ness } \\
\text { (mg/L } \\
\text { as } \\
\mathrm{CaCO}_{3} \text { ) }\end{array}$ & $\begin{array}{l}\text { Hard- } \\
\text { ness, } \\
\text { non- } \\
\text { carbo- } \\
\text { nate } \\
(\mathrm{mg} / \mathrm{L} \\
\text { as } \\
\left.\mathrm{CaCO}_{3}\right)\end{array}$ & $\begin{array}{l}\text { Spe- } \\
\text { cific } \\
\text { con- } \\
\text { duc- } \\
\text { tance } \\
\text { ( } \mu \text { mho) }\end{array}$ & $\begin{array}{c}\mathrm{pH} \\
\text { (units) }\end{array}$ & $\begin{array}{l}\text { Tem- } \\
\text { pera- } \\
\text { ture } \\
\left({ }^{\circ} \mathrm{C}\right)\end{array}$ & $\begin{array}{l}\text { Stron- } \\
\text { tium, } \\
\text { dis- } \\
\text { solved } \\
\text { ( } \mu \mathrm{g} / \mathrm{L} \\
\text { as } \mathrm{Sr} \text { ) }\end{array}$ \\
\hline 18 & $\begin{array}{l}5-28-74 \\
9-17-74 \\
4-28-75 \\
9-02-75 \\
5-04-76 \\
9-17-76 \\
5-03-77 \\
9-02-77 \\
6-29-78 \\
9-06-78\end{array}$ & $\begin{array}{l}-- \\
-- \\
-- \\
-- \\
-- \\
-- \\
-- \\
-- \\
-- \\
--\end{array}$ & $\begin{array}{l}-- \\
-- \\
-- \\
-- \\
-- \\
-- \\
-- \\
-- \\
-- \\
--\end{array}$ & $\begin{array}{l}-- \\
-- \\
-- \\
-- \\
-- \\
-- \\
-- \\
-- \\
-- \\
--\end{array}$ & $\begin{array}{l}478 \\
630 \\
384 \\
450 \\
420 \\
520 \\
700 \\
468 \\
395 \\
342\end{array}$ & $\begin{array}{l}- \\
- \\
- \\
- \\
- \\
7.4 \\
- \\
- \\
7.8 \\
7.5\end{array}$ & $\begin{array}{l}25.0 \\
25.5 \\
24.0 \\
27.0 \\
25.0 \\
25.5 \\
25.0 \\
24.0 \\
25.0 \\
23.0\end{array}$ & $\begin{array}{l}-- \\
-- \\
-- \\
-- \\
-- \\
-- \\
-- \\
-- \\
-- \\
--\end{array}$ \\
\hline 19 & $\begin{array}{l}8-03-65 \\
5-19-66\end{array}$ & $\begin{array}{r}621 \\
1,410\end{array}$ & $\begin{array}{l}170 \\
344\end{array}$ & $\begin{array}{r}94 \\
232\end{array}$ & $\begin{array}{l}1,150 \\
2,730\end{array}$ & $\begin{array}{l}7.0 \\
7.0\end{array}$ & $\begin{array}{l}-- \\
--\end{array}$ & -- \\
\hline 20 & $\begin{array}{r}3-25-64 \\
10-16-64 \\
8-04-65\end{array}$ & $\begin{array}{r}-- \\
113 \\
120\end{array}$ & $\begin{array}{l}99 \\
96 \\
98\end{array}$ & $\begin{array}{l}7 \\
8 \\
8\end{array}$ & $\begin{array}{l}225 \\
192 \\
215\end{array}$ & $\begin{array}{l}7.2 \\
7.9 \\
7.2\end{array}$ & $\begin{array}{l}-- \\
-- \\
--\end{array}$ & $\begin{array}{l}-- \\
-- \\
--\end{array}$ \\
\hline $\begin{array}{l}21 \\
22\end{array}$ & $\begin{array}{r}10-16-64 \\
8-03-65 \\
5-18-66 \\
5-19-67 \\
5-02-68 \\
5-31-68\end{array}$ & $\begin{array}{r}188 \\
234 \\
-- \\
920 \\
2,450 \\
2,190\end{array}$ & $\begin{array}{r}112 \\
122 \\
1,230 \\
176 \\
520 \\
496\end{array}$ & $\begin{array}{r}17 \\
27 \\
1,120 \\
75 \\
408 \\
389\end{array}$ & $\begin{array}{r}338 \\
440 \\
-- \\
1,720 \\
4,480 \\
4,010\end{array}$ & $\begin{array}{l}7.8 \\
7.3 \\
7.4 \\
7.8 \\
7.4 \\
7.5\end{array}$ & $\begin{array}{c}-- \\
-- \\
-- \\
24.0 \\
25.0 \\
27.0\end{array}$ & $\begin{array}{l}-- \\
-- \\
-- \\
330 \\
640 \\
610\end{array}$ \\
\hline & $\begin{array}{r}5-12-69 \\
6-13-69 \\
6-08-70 \\
10-13-70 \\
4-28-71 \\
10-05-71 \\
5-10-72 \\
9-20-72 \\
4-30-73 \\
10-18-73\end{array}$ & $\begin{array}{r}918 \\
6,020 \\
1,200 \\
-- \\
1,140 \\
5,060 \\
4,710 \\
11,000 \\
1,860 \\
2,140\end{array}$ & $\begin{array}{r}265 \\
1,200 \\
296 \\
-- \\
290 \\
1,200 \\
970 \\
2,100 \\
450 \\
610\end{array}$ & $\begin{array}{r}160 \\
1,100 \\
193 \\
-- \\
186 \\
1,100 \\
870 \\
2,000 \\
340 \\
500\end{array}$ & $\begin{array}{r}1,750 \\
10,400 \\
2,240 \\
6,300 \\
2,160 \\
7,600 \\
8,100 \\
19,000 \\
3,500 \\
3,130\end{array}$ & $\begin{array}{l}7.7 \\
7.8 \\
7.9 \\
- \\
7.9 \\
7.8 \\
8.2 \\
7.9 \\
8.2 \\
7.7\end{array}$ & $\begin{array}{l}26.0 \\
29.0 \\
26.0 \\
29.0 \\
25.5 \\
24.5 \\
27.0 \\
29.5 \\
23.5 \\
23.0\end{array}$ & $\begin{array}{r}-- \\
-- \\
-- \\
-- \\
440 \\
1,300 \\
870 \\
4,800 \\
600 \\
--\end{array}$ \\
\hline & $\begin{array}{r}4-04-74 \\
10-17-74 \\
4-18-75 \\
10-24-75 \\
9-17-76 \\
5-03-77 \\
5-10-78\end{array}$ & $\begin{array}{r}1,230 \\
917 \\
1,490 \\
2,320 \\
1,210 \\
1,320 \\
1,180\end{array}$ & $\begin{array}{l}300 \\
240 \\
320 \\
520 \\
320 \\
330 \\
290\end{array}$ & $\begin{array}{l}200 \\
130 \\
210 \\
410 \\
220 \\
230 \\
190\end{array}$ & $\begin{array}{r}2,230 \\
1,560 \\
-- \\
4,100 \\
2,340 \\
1,200 \\
2,310\end{array}$ & $\begin{array}{l}7.4 \\
7.5 \\
- \\
- \\
- \\
8.1 \\
8.0\end{array}$ & $\begin{array}{l}25.5 \\
25.0 \\
23.5 \\
23.0 \\
26.0 \\
23.0 \\
26.5\end{array}$ & $\begin{array}{l}370 \\
310 \\
490 \\
760 \\
410 \\
490 \\
450\end{array}$ \\
\hline
\end{tabular}

